\title{
Mechanism of Z-Selective Hydroalkylation of Terminal Alkynes
}

\author{
Mitchell T. Lee and Gojko Lalic* \\ Department of Chemistry, University of Washington, Seattle, Washington 98195, United States \\ email: lalic@chem.washington.edu
}




\section{Table of Contents}

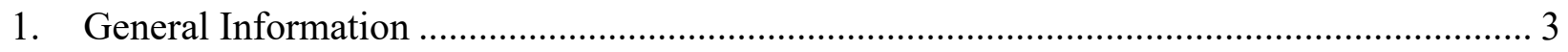

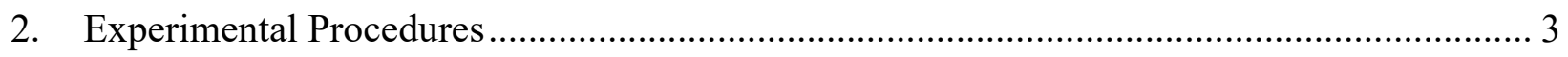

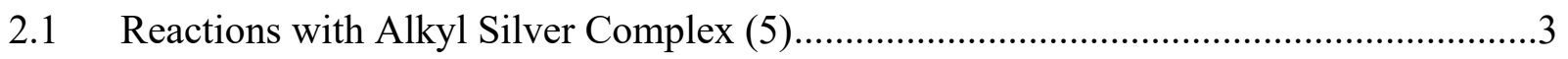

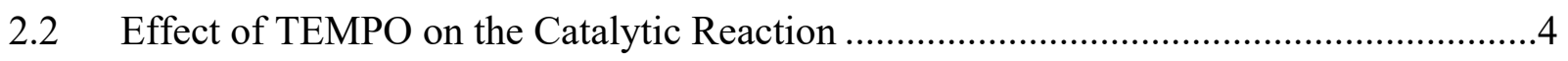

2.3 Reaction of Silver Acetylide with Alkyl Borane and $t$-BuOH ……..............................

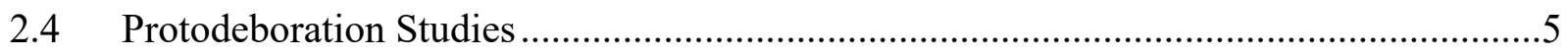

2.5 Transmetalation and Protodeargentation Study ..........................................................

2.6 Acidity of Alkenyl and Alkynyl Silver Complexes .......................................................6

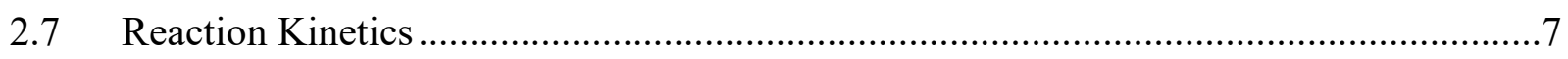

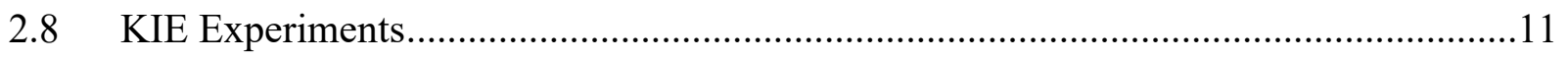

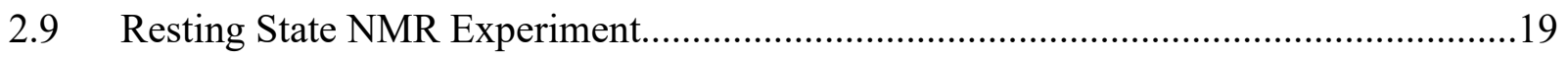

2.10 Variable Temperature NMR Experiments ................................................................19

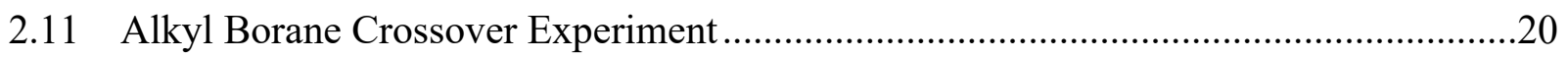

3. Characterization of Organic Reagents and Products ………............................................. 20

4. Synthesis and Characterization of TriAg and IPrAg Complexes ......................................... 22

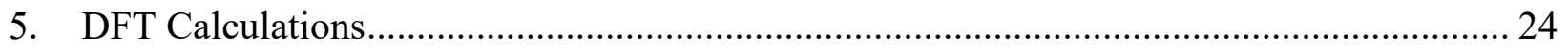

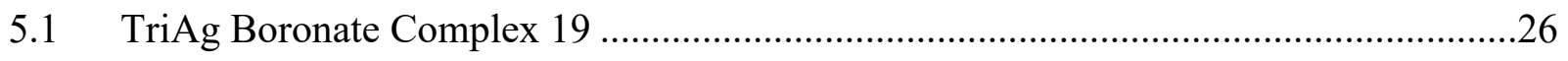

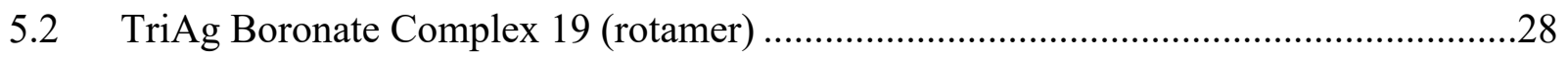

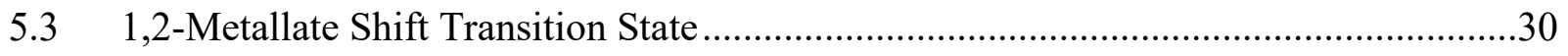

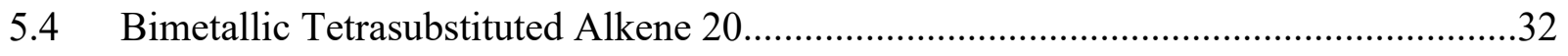

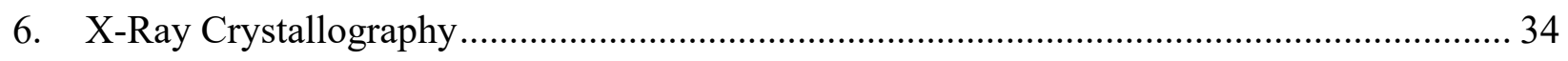

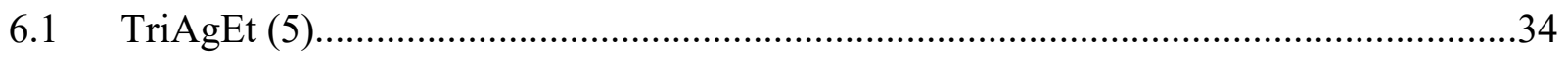

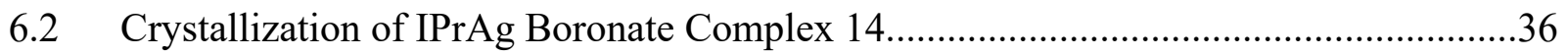

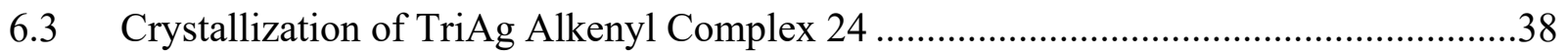

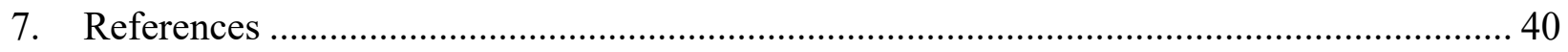

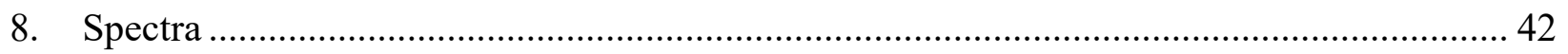




\section{General Information}

All reactions were performed under a nitrogen atmosphere with flame-dried or oven-dried (120 $\left.{ }^{\circ} \mathrm{C}\right)$ glassware, using standard Schlenk techniques, or in a glovebox (Nexus II from Vacuum Atmospheres). Column chromatography was performed using a Biotage Iso-1SV flash purification system with silica gel from Agela Technologies Inc. ${ }^{1} \mathrm{H}$ - and ${ }^{13} \mathrm{C}-\mathrm{NMR}$ spectra were recorded on a Bruker AV-300 or AV-500 spectrometer. ${ }^{1} \mathrm{H}$ NMR chemical shifts $(\delta)$ are reported in parts per million (ppm) downfield of TMS and are referenced relative to residual solvent peak $\left(\mathrm{CDCl}_{3}(7.26\right.$ $\mathrm{ppm}), \mathrm{C}_{6} \mathrm{D}_{6}(7.16 \mathrm{ppm})$, or toluene- $d_{8}(2.09 \mathrm{ppm}) .{ }^{13} \mathrm{C}$ NMR chemical shifts are reported in parts per million downfield of TMS and are referenced to the carbon resonance of the solvent $\left(\mathrm{CDCl}_{3}(77.2 \mathrm{ppm})\right.$, or $\left.\mathrm{C}_{6} \mathrm{D}_{6}(128.1 \mathrm{ppm})\right)$. Data are represented as follows: chemical shift, multiplicity $(\mathrm{s}=$ singlet, $\mathrm{d}=$ doublet, $\mathrm{t}=$ triplet, $\mathrm{q}=$ quartet, $\mathrm{p}=$ pentet, hept $=$ heptet, $\mathrm{m}=$ multiplet $)$, coupling constants in Hertz (Hz), intergration. Mass spectra were collected on a JEOL HX-110 mass spectrometer. Gas Chromatography (GC) analysis was performed on a Shimadzu GC-2010 instrument with a flame ionization detector and a SHRXI-5MS column $(15 \mathrm{~m}, 0.25 \mathrm{~mm}$ inner diameter, $0.25 \mu \mathrm{m}$ film thickness). The following temperature program was used: $2 \mathrm{~min} @ 60{ }^{\circ} \mathrm{C}$, $13{ }^{\circ} \mathrm{C} / \mathrm{min}$ to $160{ }^{\circ} \mathrm{C}, 30^{\circ} \mathrm{C} / \mathrm{min}$ to $250^{\circ} \mathrm{C}, 5.5 \mathrm{~min} @ 250^{\circ} \mathrm{C}$.

Materials: THF, $\mathrm{CH}_{2} \mathrm{Cl}_{2}$, ether, benzene, pentane, and toluene were degassed and dried by passing through columns of neutral alumina. Anhydrous methanol, deuterated methanol, and deuterated tert- were purchased from Millipore Sigma, degassed and stored over $4 \AA$ molecular sieves. Isooctane was purchased from Fisher Scientific and was degassed and stored over 4Åmolecular sieves. Deuterated NMR solvents were purchased from Cambridge Isotope Laboratories, Inc. and were either used as received or degassed and stored over $4 \AA$ molecular sieves prior to use. Commercial reagents were purchased from Millipore Sigma, TCI America, GFS-Chemicals, ArkPharm, Combi-Blocks, Oakwood Chemicals, Strem Chemicals and Alfa Aesar. 9-BBN Dimer was purchased from Millipore Sigma and recrystallized from THF.

\section{Experimental Procedures}

\subsection{Reactions with Alkyl Silver Complex (5)}

2.1.1 Without Methanol

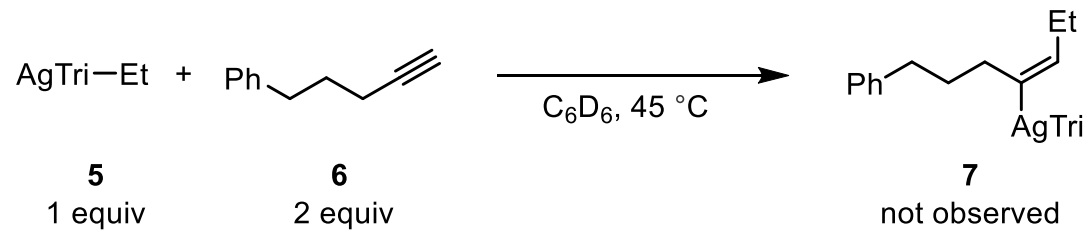

In a nitrogen filled glovebox, alkyl silver complex $5(6.0 \mathrm{mg}, 0.01 \mathrm{mmol}, 1$ equiv.) was added using $3 \times 100 \mathrm{uL} \mathrm{C}_{6} \mathrm{D}_{6}$ to a J-Young tube. To this was added $100 \mathrm{uL}$ of an $8.4 \mathrm{mg} / \mathrm{mL}$ solution of internal standard, trimethoxy benzene (TMB), $(0.8 \mathrm{mg}, 0.05 \mathrm{mmol}, 0.5$ equiv.) in $\mathrm{C}_{6} \mathrm{D}_{6}$. An NMR spectrum of this solution was then recorded. The J-Young tube was then returned to the glovebox and $100 \mathrm{uL}$ of a $28.8 \mathrm{mg} / \mathrm{mL}$ solution of alkyne $6(2.9 \mathrm{mg} 0.02$ mmol, 2.0 equiv.) in $\mathrm{C}_{6} \mathrm{D}_{6}$ was added. An NMR spectrum of this mixture was then recorded. The J-Young tube was heated at $45^{\circ} \mathrm{C}$ for $20 \mathrm{~min}$ and another NMR spectrum was recorded. 
2.1.2 With Methanol

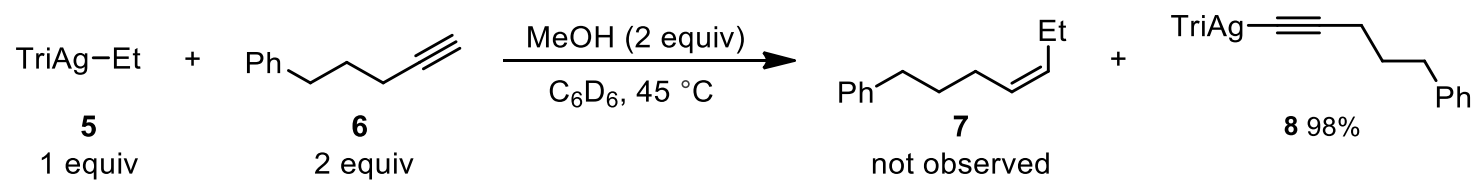

In a nitrogen filled glovebox, alkyl silver complex $5(6.0 \mathrm{mg}, 0.01 \mathrm{mmol}, 1$ equiv.) was added using $3 \times 100 \mathrm{uL} \mathrm{C}_{6} \mathrm{D}_{6}$ to a J-Young tube. To this was added $100 \mathrm{uL}$ of an $8 \mathrm{mg} / \mathrm{mL}$ solution of internal standard, TMB $\left(0.8 \mathrm{mg}, 0.005 \mathrm{mmol}, 0.5\right.$ equiv.) in $\mathrm{C}_{6} \mathrm{D}_{6}$. An NMR spectrum of this solution was then recorded. The J-Young tube was then returned to the glovebox and $50 \mathrm{uL}$ of a $57.6 \mathrm{mg} / \mathrm{mL}$ solution of alkyne $\mathbf{6}(2.9 \mathrm{mg} 0.02 \mathrm{mmol}, 2.0$ equiv.) in $\mathrm{C}_{6} \mathrm{D}_{6}$ was added. This was followed by $50 \mathrm{uL}$ of a $10.2 \mathrm{mg} / \mathrm{mL}$ solution of $\mathrm{MeOH}(0.5$ $\mathrm{mg}, 0.015 \mathrm{mmol}, 1.5$ equiv.) in $\mathrm{C}_{6} \mathrm{D}_{6}$ and an NMR spectrum was then recored. The J-Young tube was then heated at $45^{\circ} \mathrm{C}$ and NMR spectra were obtained after 1 hour $(70 \%$ yield of TriAg acetylide 8) and 18 hours (98\% yield of TriAg Acetylide 8).

\subsection{Effect of TEMPO on the Catalytic Reaction}
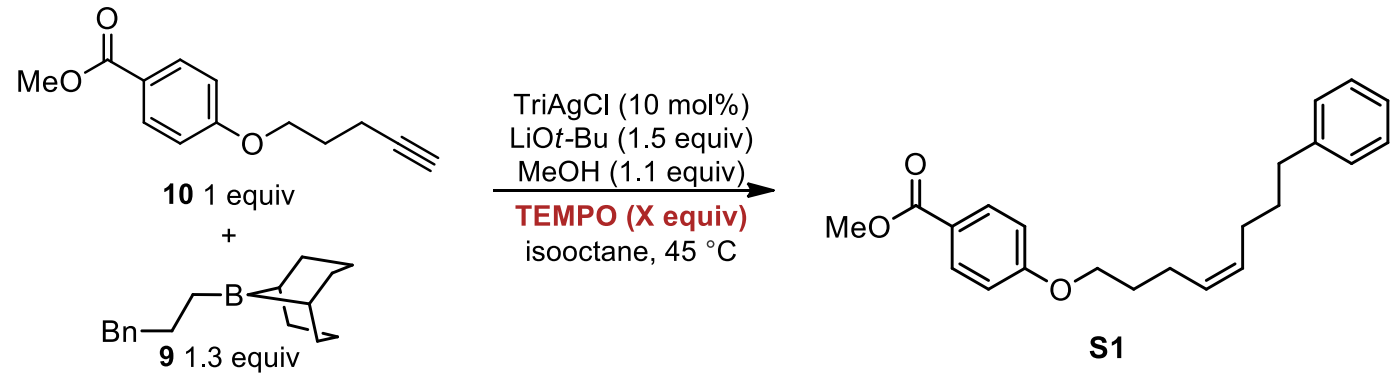

$\begin{array}{cccccc}\text { TEMPO (X equiv) } & 0.0 & 0.2 & 0.5 & 1.0 & 2.5 \\ \text { yield of XX } & 91 \% & 91 \% & 87 \% & 76 \% & 37 \%\end{array}$

In a nitrogen filled glovebox, a series of five 1-dram vials were each charged with a stir bar and $\mathrm{LiOt}$ - $\mathrm{Bu}(6.0 \mathrm{mg}, 0.075 \mathrm{mmol}, 1.5$ equiv). To these was added $\mathrm{TriAgCl}$ catalyst ( $3.0 \mathrm{mg}, 0.005 \mathrm{mmol}, 0.10$ equiv), and alkyne $\mathbf{S 1}$ (10.9 $\mathrm{mg} 0.050 \mathrm{mmol}, 1.0$ equiv). To this was added TMB ( $4.2 \mathrm{mg}, 0.025 \mathrm{mmol}, 0.5$ equiv) with $3 \times 100 \mathrm{uL}$ isooctane, $50 \mathrm{uL}$ of a 31.2 $\mathrm{mg} / \mathrm{mL}$ solution of alkylborane $9(15.6 \mathrm{mg}, 0.065 \mathrm{mmol}, 1.3$ equiv), and $50 \mathrm{uL}$ of a warmed (just enough to dissolve the methanol) solution of $35.2 \mathrm{mg} / \mathrm{mL}$ methanol $(1.8 \mathrm{mg}, 0.055$ mmol, 1.10 equiv) in isooctane. The specified amount of TEMPO was then added to each reaction as $100 \mathrm{uL}$ of the needed stock solution in isooctane. The reaction mixtures were heated to $45^{\circ} \mathrm{C}$ and stirred overnight. After 16 hours, $25 \mathrm{uL}$ aliquots of the crude reaction mixtures were pushed through short plugs of silica with ethyl acetate and analyzed by GC.

\subsection{Reaction of Silver Acetylide with Alkyl Borane and $t$-BuOH}

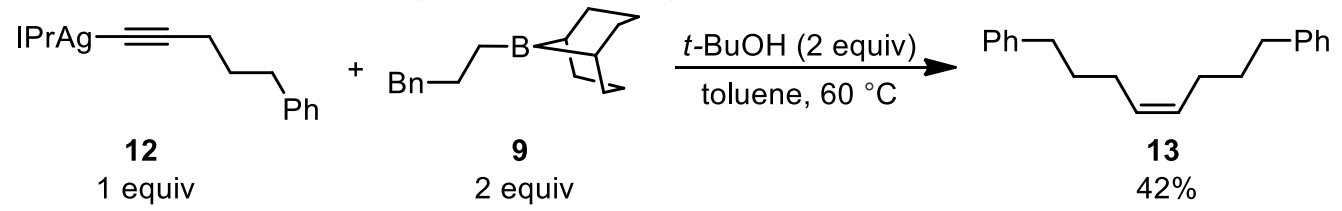

In a nitrogen filled glovebox, a 1-dram vial was charged with a stir bar and silver acetylide complex 12 (32.0 mg, $0.05 \mathrm{mmol}, 1$ equiv.). To this was added $100 \mathrm{uL}$ of a $42.0 \mathrm{mg} / \mathrm{mL}$ solution of internal standard, trimethoxy benzene (TMB), $(4.2 \mathrm{mg}, 0.025 \mathrm{mmol}, 0.5$ equiv.) 
in toluene. This was followed by alkyl borane 9 ( $24.0 \mathrm{mg} 0.10 \mathrm{mmol}, 2.0$ equiv.) using 3 portions of $100 \mathrm{uL}$ toluene. Finally, $100 \mathrm{uL}$ of a $74.1 \mathrm{mg} / \mathrm{mL}$ solution of $t-\mathrm{BuOH}(7.4 \mathrm{mg}$, $0.10 \mathrm{mmol}, 2.0$ equiv) in toluene was added. The reaction mixture was heated to $60^{\circ} \mathrm{C}$ and stirred overnight. The next day a $25 \mathrm{uL}$ aliquot of the crude reaction mixture was pushed through a short plug of silica with ethyl acetate and analyzed by GC.

\subsection{Protodeboration Studies}

A stock solution of $116.1 \mathrm{mg} / \mathrm{mL}$ alkenyl borane 21 and $42.0 \mathrm{mg} / \mathrm{mL}$ TMB in isooctane was prepared and used for the following experiments.

2.4.1 $\mathrm{MeOH}$ or $t-\mathrm{BuOH}$

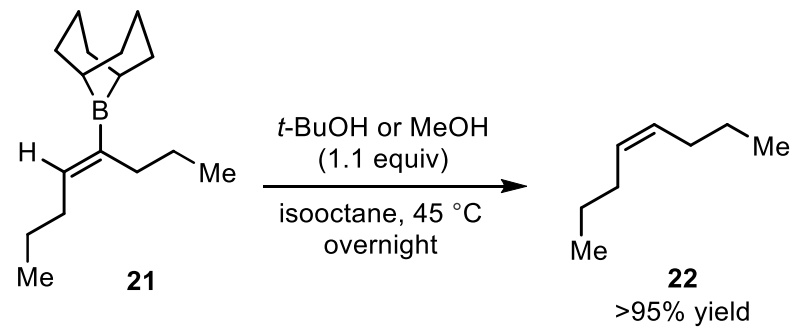

In a nitrogen filled glovebox, two 1-dram vials were charged with a stir bar and $300 \mathrm{uL}$ isooctane was added. To these was added $100 \mathrm{uL}$ of the stock solution of alkenyl borane 21 (11.6 mg, $0.05 \mathrm{mmol}, 1.0$ equiv.) and TMB ( $4.2 \mathrm{mg}, 0.05 \mathrm{mmol}, 0.5$ equiv). To this was added $100 \mathrm{uL}$ of either a warmed $17.6 \mathrm{mg} / \mathrm{mL}$ solution of $\mathrm{MeOH}(1.8 \mathrm{mg}, 0.055 \mathrm{mmol}, 1.1$ equiv) in isooctane or a $40.8 \mathrm{mg} / \mathrm{mL}$ solution of $t-\mathrm{BuOH}$ ( $4.1 \mathrm{mg}, 0.055 \mathrm{mmol}, 1.1$ equiv) in isooctane. The reaction mixture was heated to $45^{\circ} \mathrm{C}$ and stirred overnight. The next day an aliquot of the crude reaction mixture was added to $\mathrm{C}_{6} \mathrm{D}_{6}$ in the glovebox and then a crude NMR spectrum was recorded.

\subsubsection{With $\mathrm{LiO} t-\mathrm{Bu}$ and Alcohol}

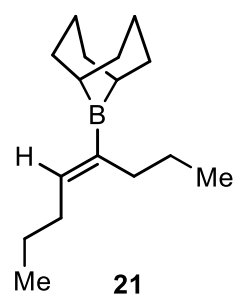

21

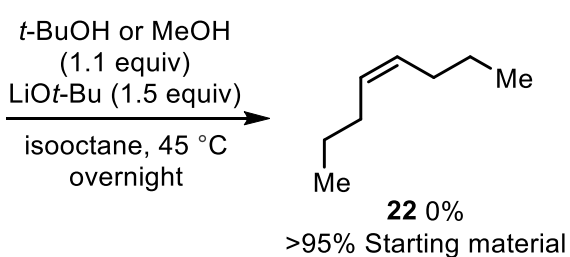

In a nitrogen filled glovebox, two 1-dram vials were charged with a stir bar and $\mathrm{LiO} t-\mathrm{Bu}$ ( $6.0 \mathrm{mg}, 0.075 \mathrm{mmol}, 1.5$ equiv) and then $300 \mathrm{uL}$ isooctane was added. To this was added $100 \mathrm{uL}$ of the stock solution of alkenyl borane 21 (11.6 mg, $0.05 \mathrm{mmol}, 1.0$ equiv.) and TMB (4.2 mg, $0.05 \mathrm{mmol}, 0.5$ equiv). To this was added $100 \mathrm{uL}$ of either a warmed 17.6 $\mathrm{mg} / \mathrm{mL}$ solution of $\mathrm{MeOH}(1.8 \mathrm{mg}, 0.055 \mathrm{mmol}, 1.1$ equiv) in isooctane or a $40.8 \mathrm{mg} / \mathrm{mL}$ solution of $t-\mathrm{BuOH}(4.1 \mathrm{mg}, 0.055 \mathrm{mmol}, 1.1$ equiv) in isooctane. The reaction mixture was heated to $45^{\circ} \mathrm{C}$ and stirred overnight. The next day an aliquot of the crude reaction mixture was added to $\mathrm{C}_{6} \mathrm{D}_{6}$ in the glovebox and then a crude NMR spectrum was recorded. 
2.4.3 With TriAgCl, Base, and Alcohol
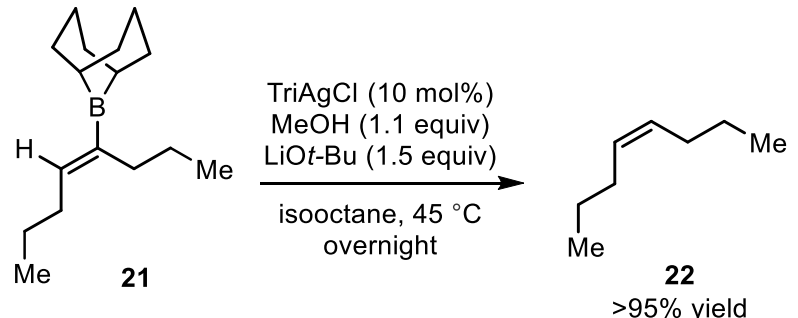

In a nitrogen filled glovebox, a 1-dram vial was charged with a stir bar, $\mathrm{TriAgCl}(3.0 \mathrm{mg}$, $0.005 \mathrm{mmol}, 0.10$ equiv), and $\mathrm{LiO} t-\mathrm{Bu}(6.0 \mathrm{mg}, 0.075 \mathrm{mmol}, 1.5$ equiv) and then $300 \mathrm{uL}$ isooctane was added. To this was added $100 \mathrm{uL}$ of the stock solution of alkenyl borane $\mathbf{2 1}$ (11.6 mg, $0.05 \mathrm{mmol}, 1.0$ equiv.) and TMB ( $4.2 \mathrm{mg}, 0.05 \mathrm{mmol}, 0.5$ equiv). To this was added $100 \mathrm{uL}$ of a warmed $17.6 \mathrm{mg} / \mathrm{mL}$ solution of $\mathrm{MeOH}$ (1.8 $\mathrm{mg}, 0.055 \mathrm{mmol}, 1.1$ equiv) in isooctane. The reaction mixture was heated to $45^{\circ} \mathrm{C}$ and stirred overnight. The next day an aliquot of the crude reaction mixture was added to $\mathrm{C}_{6} \mathrm{D}_{6}$ in the glovebox and then a crude NMR spectrum was recorded.

\subsection{Transmetalation and Protodeargentation Study}

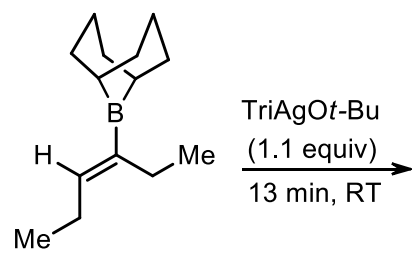

23

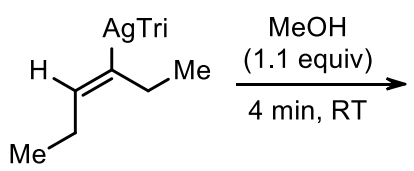

24

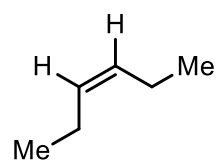

25

In a nitrogen filled glovebox, a 1-dram vial was charged with a stir bar and TriAgOtBu (14.2 $\mathrm{mg}, 0.022 \mathrm{mmol}, 1.1$ equiv) and then $350 \mathrm{uL} \mathrm{C}_{6} \mathrm{D}_{6}$ was added. To this was added 100 $\mathrm{uL}$ of a stock solution of $40.8 \mathrm{mg} / \mathrm{mL}$ alkenyl borane 23 ( $4.1 \mathrm{mg}, 0.02 \mathrm{mmol}, 1.0$ equiv.) and $16.8 \mathrm{mg} / \mathrm{mL}$ TMB $(1.6 \mathrm{mg}, 0.01 \mathrm{mmol}, 0.5$ equiv). The reaction was then stirred $5 \mathrm{~min}$ at $25^{\circ} \mathrm{C}$ and transferred to an NMR tube. While stirring, $50 \mathrm{uL}$ of a $14.0 \mathrm{mg} / \mathrm{mL}$ solution of $\mathrm{MeOH}\left(0.7 \mathrm{mg}, 0.022 \mathrm{mmol}, 1.1\right.$ equiv) in $\mathrm{C}_{6} \mathrm{D}_{6}$ was drawn into a syringe. After being transferred to an NMR tube, NMR tube and syringe were taken to the NMR facility and an NMR spectrum was recorded ( 8 min later). After ejection, the methanol solution was added by injecting the needle through the cap and covering with parafilm. A second spectrum was then obtained (4 min after methanol addition).

\subsection{Acidity of Alkenyl and Alkynyl Silver Complexes}

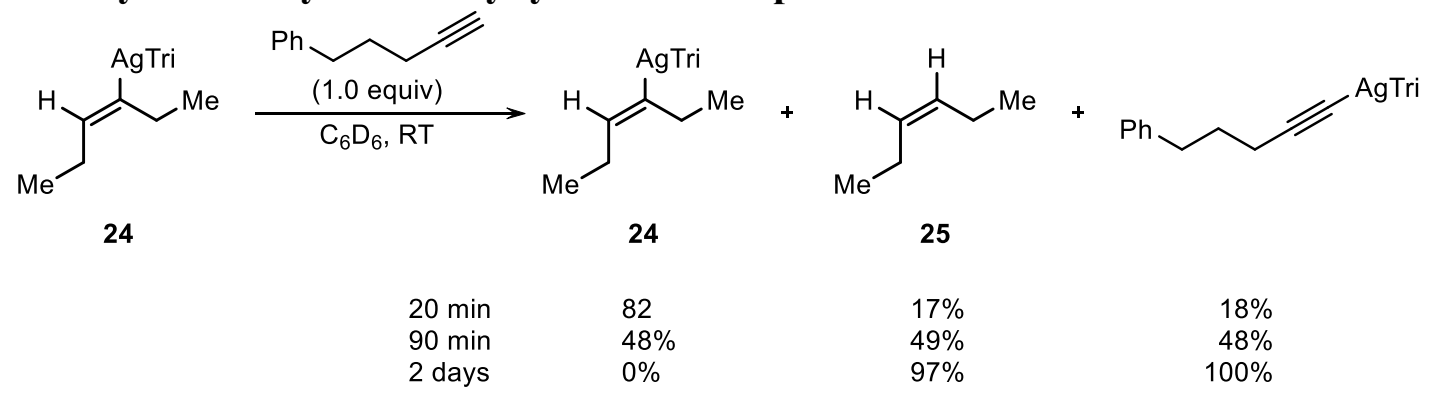

In a nitrogen filled glovebox, a 1-dram vial was charged with a stir bar and TriAgOtBu ( $27.2 \mathrm{mg}, 0.042 \mathrm{mmol}, 2.1$ equiv) and then $600 \mathrm{uL} \mathrm{C}_{6} \mathrm{D}_{6}$ was added. To this was added 200 
$\mathrm{uL}$ of a stock solution of $40.8 \mathrm{mg} / \mathrm{mL}$ alkenyl borane $23(8.2 \mathrm{mg}, 0.04 \mathrm{mmol}, 2.0$ equiv.) and $33.6 \mathrm{mg} / \mathrm{mL}$ TMB $(3.4 \mathrm{mg}, 0.02 \mathrm{mmol}, 1.0$ equiv). The reaction was then stirred $5 \mathrm{~min}$ at $25^{\circ} \mathrm{C}$ and split between two NMR tubes ( $400 \mathrm{uL}$ each). $100 \mathrm{uL} \mathrm{C}_{6} \mathrm{D}_{6}$ was then added to one tube. To the other was added $100 \mathrm{uL}$ of a stock solution of $6.4 \mathrm{mg} / \mathrm{mL}$ alkyne $6(0.6$ $\mathrm{mg}, 0.02 \mathrm{mmol} 1.0$ equiv). NMR spectra of each solution were obtained. Subsequent spectra of the solution containing added alkyne were taken at the specified times.

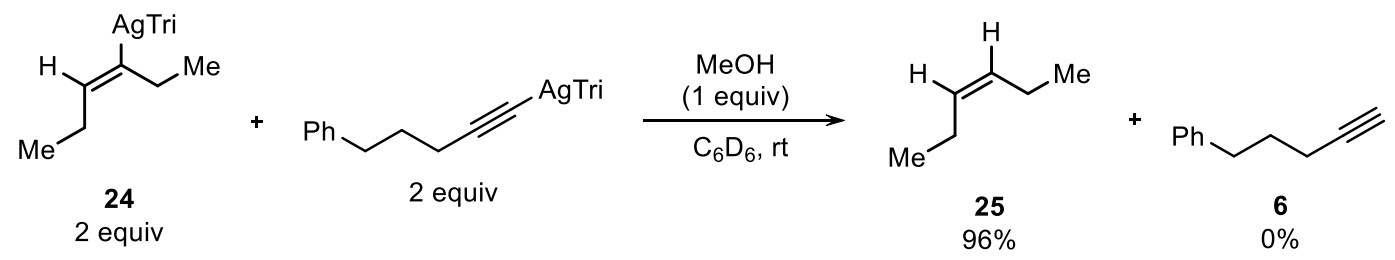

In a nitrogen filled glovebox, a 1-dram vial was charged with a stir bar and TriAgOtBu ( $40.7 \mathrm{mg}, 0.063 \mathrm{mmol}, 6.3$ equiv) and then $400 \mathrm{uL} \mathrm{C}_{6} \mathrm{D}_{6}$ was added. To this was added 200 $\mathrm{uL}$ of a stock solution of $61.2 \mathrm{mg} / \mathrm{mL}$ alkenyl borane $\mathbf{2 3}(12.2 \mathrm{mg}, 0.06 \mathrm{mmol}, 6.0$ equiv.) and $25.2 \mathrm{mg} / \mathrm{mL}$ TMB $(5.0 \mathrm{mg}, 0.03 \mathrm{mmol}, 3.0$ equiv). The reaction was then stirred $5 \mathrm{~min}$ at $25^{\circ} \mathrm{C}$ and split between 3 NMR tubes ( $200 \mathrm{uL}$ each). To one NMR tube was added 300 $\mathrm{uL} \mathrm{C}_{6} \mathrm{D}_{6}$. To the other two was added $200 \mathrm{uL}$ of a $71.7 \mathrm{mg} / \mathrm{mL}$ stock solution of the Trizole silver acetylide (14.3 mg, $0.02 \mathrm{mmol} 2.0$ equiv). One of these samples had $100 \mathrm{uL} \mathrm{C}_{6} \mathrm{D}_{6}$ added and to the other was added $100 \mathrm{uL}$ of a $6.4 \mathrm{mg} / \mathrm{mL}$ solution of $\mathrm{MeOH}(0.6 \mathrm{mg}, 0.02$ mmol, 1.0 equiv) in $\mathrm{C}_{6} \mathrm{D}_{6}$. NMR spectra of each sample were then recorded.

\subsection{Reaction Kinetics}

2.7.1 $10 \mathrm{~mol} \%$ and $20 \mathrm{~mol} \% \mathrm{TriAgCl}$
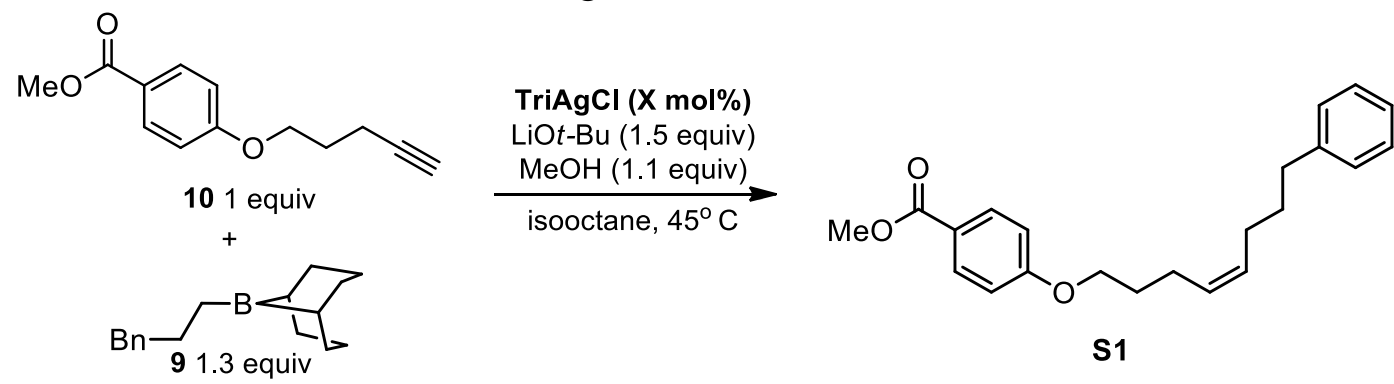

In a nitrogen filled glovebox, four 1-dram vials were each charged with a stir bar and TriAgCl catalyst (duplicates of either $6.10 \mathrm{mg}, 0.01 \mathrm{mmol}, 0.10$ equiv or $12.2 \mathrm{mg}, 0.02$ mmol, 0.20 equiv). To these was added $\mathrm{LiO} t$ - $\mathrm{Bu}(12.0 \mathrm{mg}, 0.15 \mathrm{mmol}, 1.5$ equiv), alkyne 10 (21.8 $\mathrm{mg} 0.10 \mathrm{mmol}, 1.0$ equiv) and TMB ( $8.4 \mathrm{mg}, 0.05 \mathrm{mmol}, 0.5$ equiv). To this was added $600 \mathrm{uL}$ isooctane, alkylborane $9(31.2 \mathrm{mg}, 1.3 \mathrm{mmol}, 1.3$ equiv) using $3 \times 100 \mathrm{uL}$ isooctane, and $100 \mathrm{uL}$ of a warmed solution (to dissolve $\mathrm{MeOH}$ ) of $35.2 \mathrm{mg} / \mathrm{mL}$ methanol ( $3.5 \mathrm{mg}, 0.11 \mathrm{mmol}, 1.10$ equiv) in isooctane. $25 \mathrm{uL}$ aliquots of the crude reaction mixtures were pushed through short plugs of silica with ethyl acetate at the reported times and analyzed by GC. 


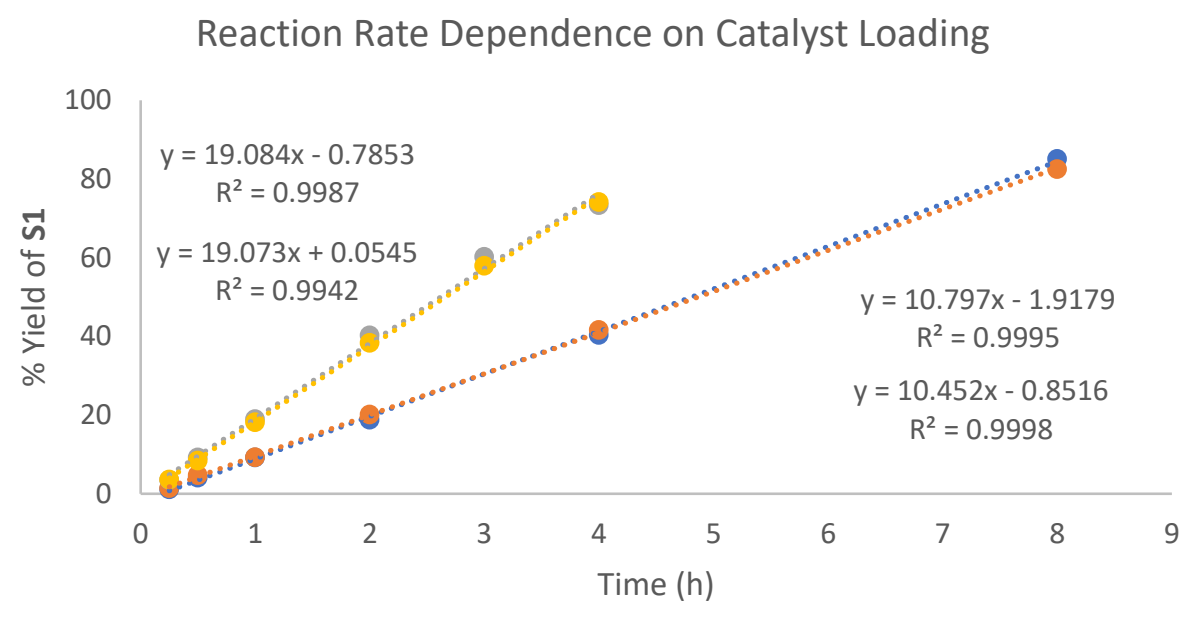

- 10 mol\% TriAgCl A 10 mol\% TriAgCl B 20 mol\% TriAgCl A 20 mol\% TriAgCl B

Rates (average of duplicate measurements)

$10 \mathrm{~mol} \%$ TriAgCl - Rate $=3.82 \times 10^{-2} \frac{\mathrm{mol}}{\mathrm{s}}$

$20 \mathrm{~mol} \%$ TriAgCl - Rate $=6.87 \times 10^{-2} \frac{\mathrm{mol}}{\mathrm{s}}$

2.7.2 Figure 2a: $10 \%$ and $20 \% \operatorname{IPrAgCl}$

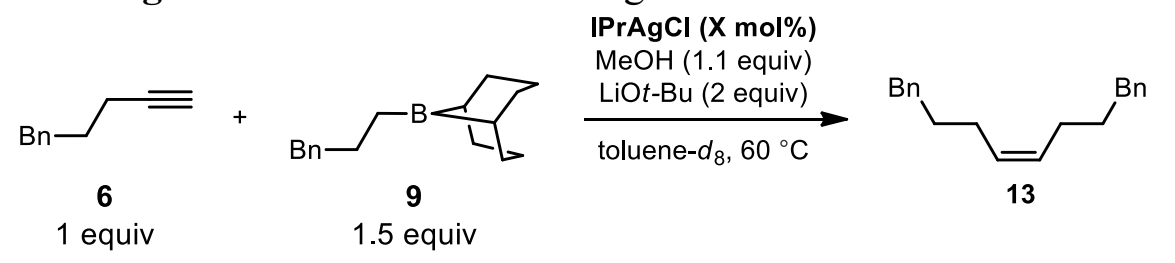

In a nitrogen filled glovebox, four 1-dram vials were each charged with a stir bar and $\mathrm{IPrAgCl}$ catalyst (duplicates of either $5.30 \mathrm{mg}, 0.01 \mathrm{mmol}, 0.10$ equiv or $10.6 \mathrm{mg}, 0.02$ mmol, 0.20 equiv). To these was added $\mathrm{LiO} t$ - $\mathrm{Bu}$ ( $16.0 \mathrm{mg}, 0.2 \mathrm{mmol}, 2.0$ equiv) and 500 $\mathrm{uL}$ toluene. To this was added $100 \mathrm{uL}$ of a stock solution of $144.2 \mathrm{mg} / \mathrm{mL}$ alkyne 6 (14.4 $\mathrm{mg}, 0.10 \mathrm{mmol}, 1.0$ equiv) and $84.1 \mathrm{mg} / \mathrm{mL} \mathrm{TMB}(8.4 \mathrm{mg}, 0.05 \mathrm{mmol}, 0.5$ equiv) in toluene, alkylborane $9(36.0 \mathrm{mg}, 0.15 \mathrm{mmol}, 1.5$ equiv) using $3 \times 100 \mathrm{uL}$ toluene, and 100 $\mathrm{uL}$ of a solution of $35.2 \mathrm{mg} / \mathrm{mL}$ methanol ( $3.5 \mathrm{mg}, 0.11 \mathrm{mmol}, 1.1$ equiv) in toluene. $25 \mathrm{uL}$ aliquots of the crude reaction mixtures were pushed through short plugs of silica with ethyl acetate at the reported times and analyzed by GC. 

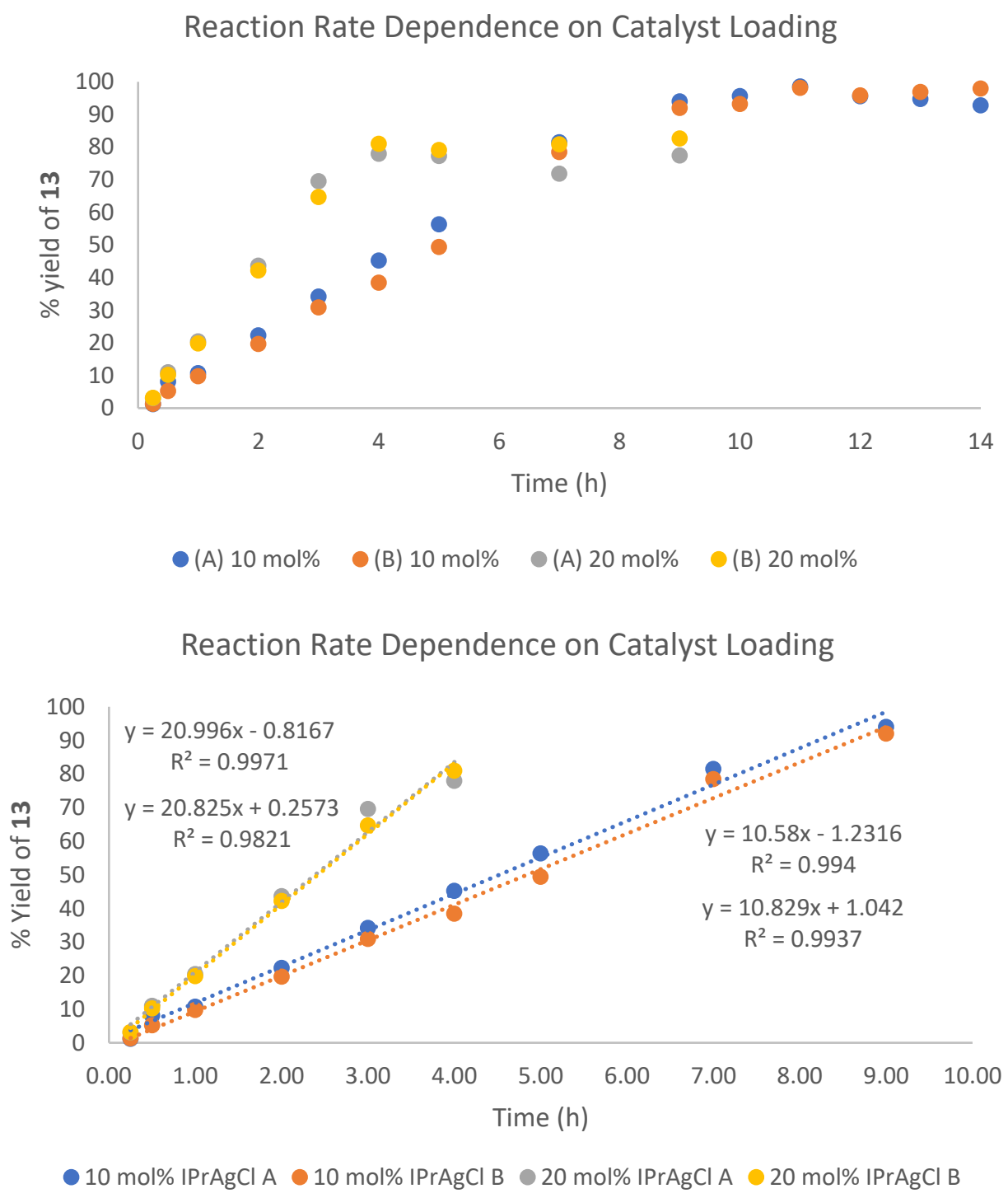

Rates (average of duplicate measurements and based on graph after removal of data points in which yield stops increasing)

$10 \mathrm{~mol} \% \mathrm{IPrAgCl}-$ Rate $=3.85 \times 10^{-2} \frac{\mathrm{mol}}{\mathrm{s}}$

$20 \mathrm{~mol} \% \mathrm{IPrAgCl}-$ Rate $=7.53 \times 10^{-2} \frac{\mathrm{mol}}{\mathrm{s}}$

2.7.3 Figure 2b: 1.5, 3.0, 5.0, and 10 Equivalents Alkyl Borane 9

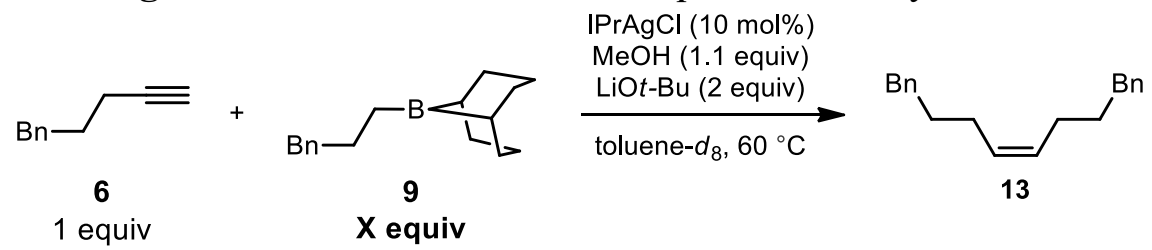

In a nitrogen filled glovebox, four 1-dram vials were each charged with a stir bar and $\mathrm{IPrAgCl}$ catalyst $(5.30 \mathrm{mg}, 0.01 \mathrm{mmol}, 0.10$ equiv). To these was added $\mathrm{LiO} t-\mathrm{Bu}(16.0 \mathrm{mg}$, 
$0.2 \mathrm{mmol}, 2.0$ equiv) and $500 \mathrm{uL}$ toluene. To this was added $100 \mathrm{uL}$ of a stock solution of $144.2 \mathrm{mg} / \mathrm{mL}$ alkyne 6 (14.4 mg, $0.10 \mathrm{mmol}, 1.0$ equiv) and $84.1 \mathrm{mg} / \mathrm{mL}$ TMB $(8.4 \mathrm{mg}$, $0.05 \mathrm{mmol}, 0.5$ equiv), alkylborane $9(1.5,3.0,5,0$, or 10.0 equiv) using $3 \times 100 \mathrm{uL}$ toluene, and $100 \mathrm{uL}$ of a solution of $35.2 \mathrm{mg} / \mathrm{mL}$ methanol $(3.5 \mathrm{mg}, 0.11 \mathrm{mmol}, 1.10$ equiv) in toluene. $25 \mathrm{uL}$ aliquots of the crude reaction mixtures were pushed through short plugs of silica with ethyl acetate at the reported times and analyzed by GC.

Reaction Rate Dependence on Alkyl Borane

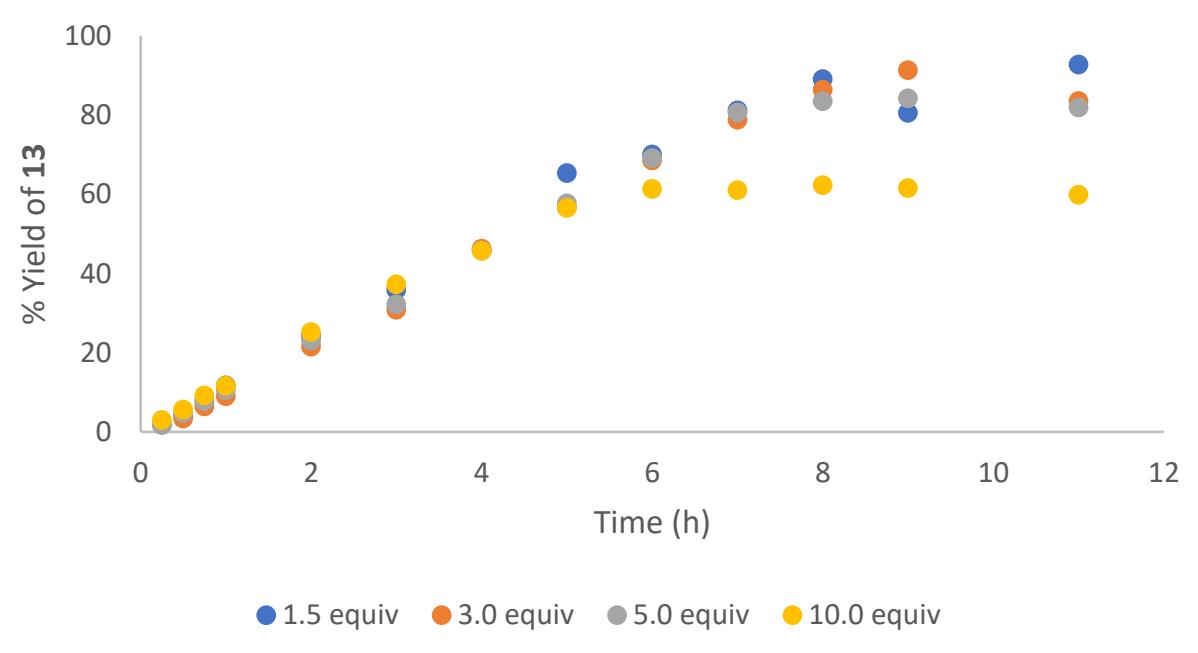

Reaction Rate Dependence on Alkyl Borane

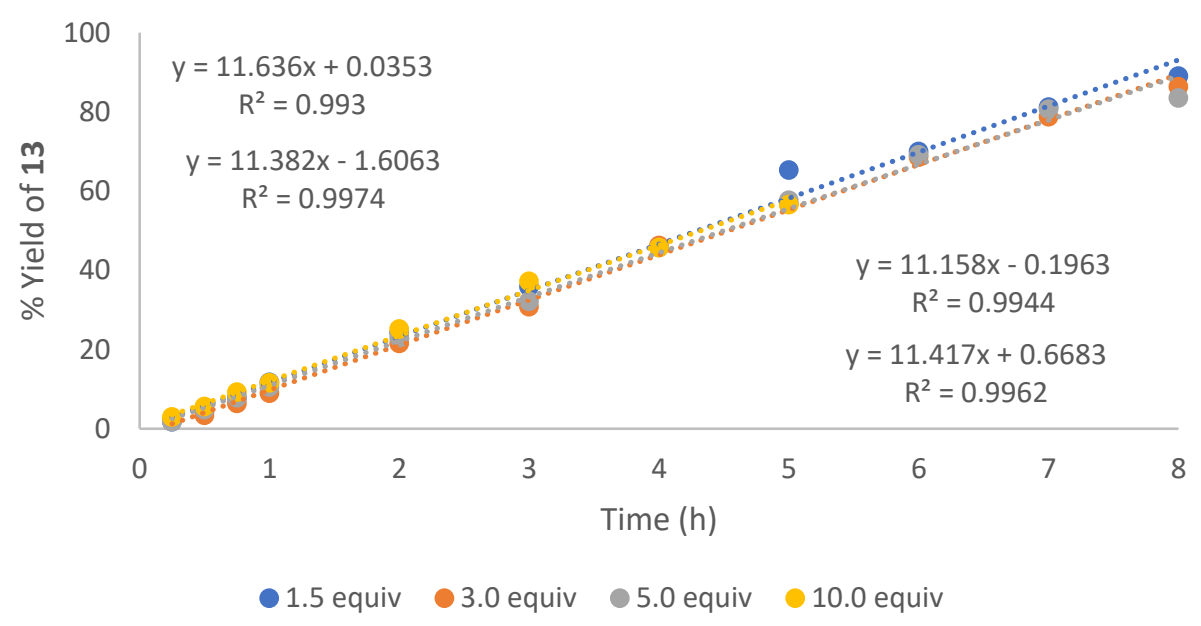

Rates (based on graph after removal of data points in which yield stops increasing)

1.5 equivalents alkyl borane - Rate $=4.19 \times 10^{-2} \frac{\mathrm{mol}}{\mathrm{s}}$

3.0 equivalents alkyl borane - Rate $=4.10 \times 10^{-2} \frac{\mathrm{mol}}{\mathrm{s}}$

5.0 equivalents alkyl borane - Rate $=4.02 \times 10^{-2} \frac{\mathrm{mol}}{\mathrm{s}}$

10.0 equivalents alkyl borane - Rate $=4.11 \times 10^{-2} \frac{\mathrm{mol}}{\mathrm{s}}$ 


\subsection{KIE Experiments}

All glassware used with $\mathrm{CD}_{3} \mathrm{OD}$ or $t$-BuOD for KIE experiments was rinsed with $\mathrm{D}_{2} \mathrm{O}$ and oven-dried $\left(120^{\circ} \mathrm{C}\right)$ overnight.

2.8.1 Independent Rate Measurements

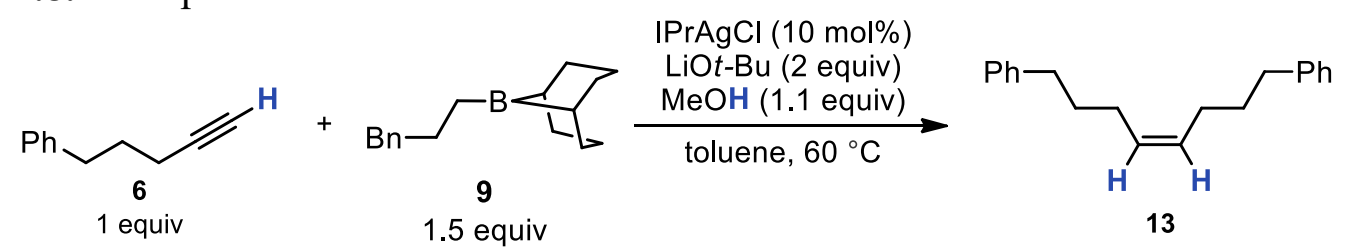

In a nitrogen filled glovebox, a 1-dram vial was charged with a stir bar and IPrAgCl catalyst (5.3 mg, $0.01 \mathrm{mmol}, 0.10$ equiv). To this was added $\mathrm{LiO} t-\mathrm{Bu}$ (16.0 mg, $0.2 \mathrm{mmol}, 2.0$ equiv) and $500 \mathrm{uL}$ toluene. To this was added $100 \mathrm{uL}$ of a stock solution of $144.2 \mathrm{mg} / \mathrm{mL}$ alkyne 6 (14.4 mg, $0.10 \mathrm{mmol}, 1.0$ equiv) and $84.1 \mathrm{mg} / \mathrm{mL}$ TMB ( $8.4 \mathrm{mg}, 0.05 \mathrm{mmol}, 0.5$ equiv). Then alkylborane 9 (36.0 $\mathrm{mg}, 0.15 \mathrm{mmol}, 1.5 \mathrm{equiv})$ using $3 \times 100 \mathrm{uL}$ toluene, and $100 \mathrm{uL}$ of a solution of $35.2 \mathrm{mg} / \mathrm{mL}$ methanol $(3.5 \mathrm{mg}, 0.11 \mathrm{mmol}, 1.1$ equiv) in toluene were added. A series of $25 \mathrm{uL}$ aliquots of the crude reaction mixtures were pushed through short plugs of silica with ethyl acetate and analyzed by GC.

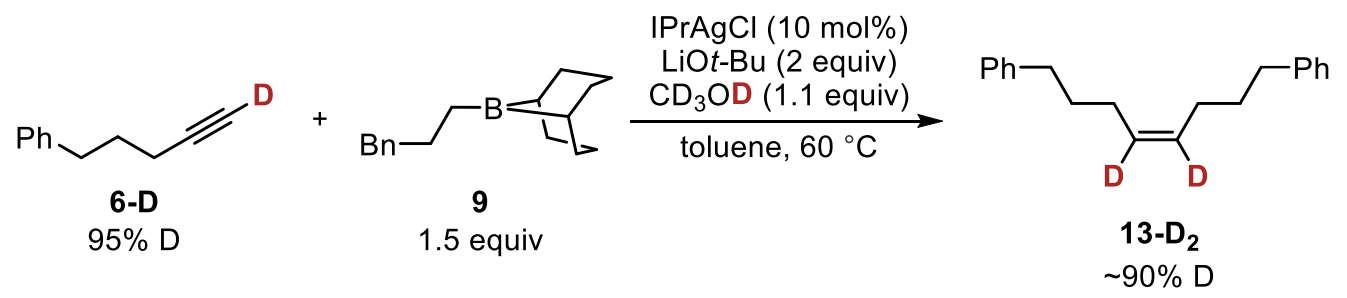

The same experiment was run using deuterated alkyne, $\mathrm{CD}_{3} \mathrm{OD}$ and glassware that had been washed with $\mathrm{D}_{2} \mathrm{O}$ and dried overnight in an oven $\left(120^{\circ} \mathrm{C}\right)$. Deuterium incorporation into the product was determined by $\mathrm{GC} / \mathrm{MS}$ for several samples.

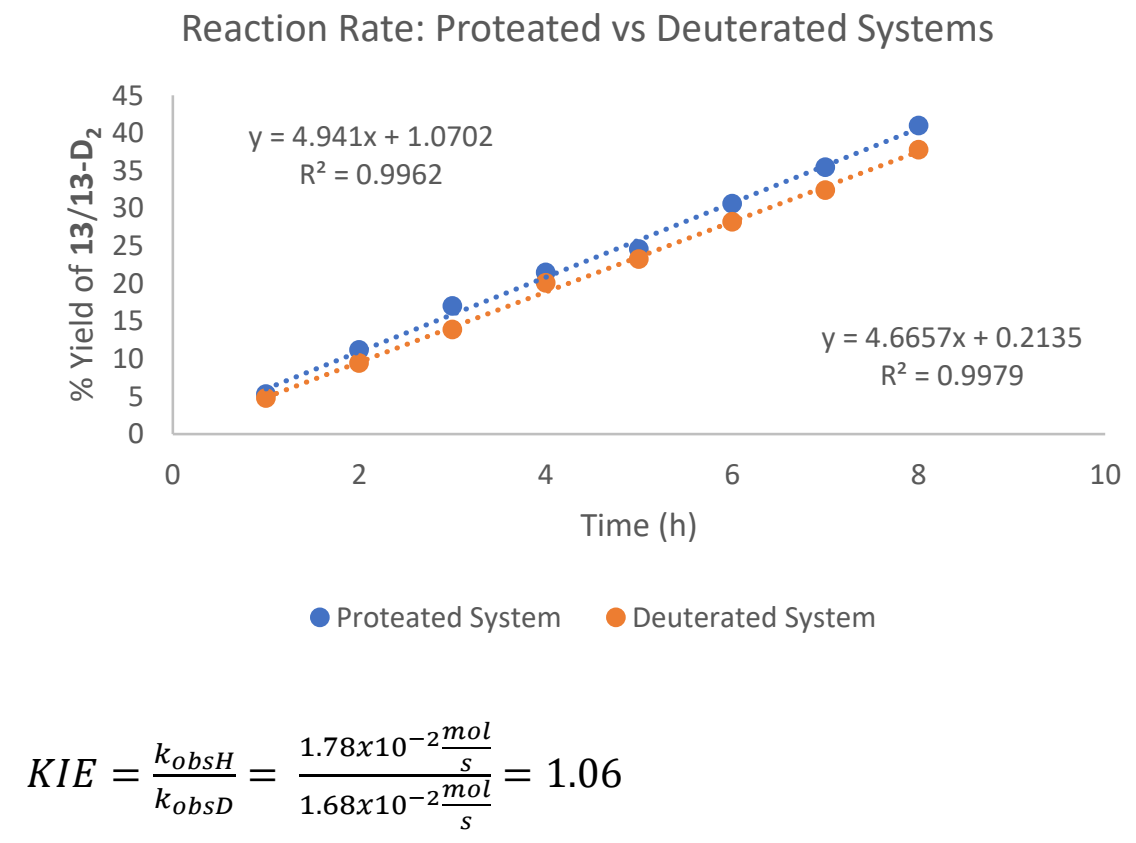


Deuterium incorporation at 20,38, and $69 \%$ product yield

Mass spectrum of the reaction with proteated substrate at $21 \%$ yield

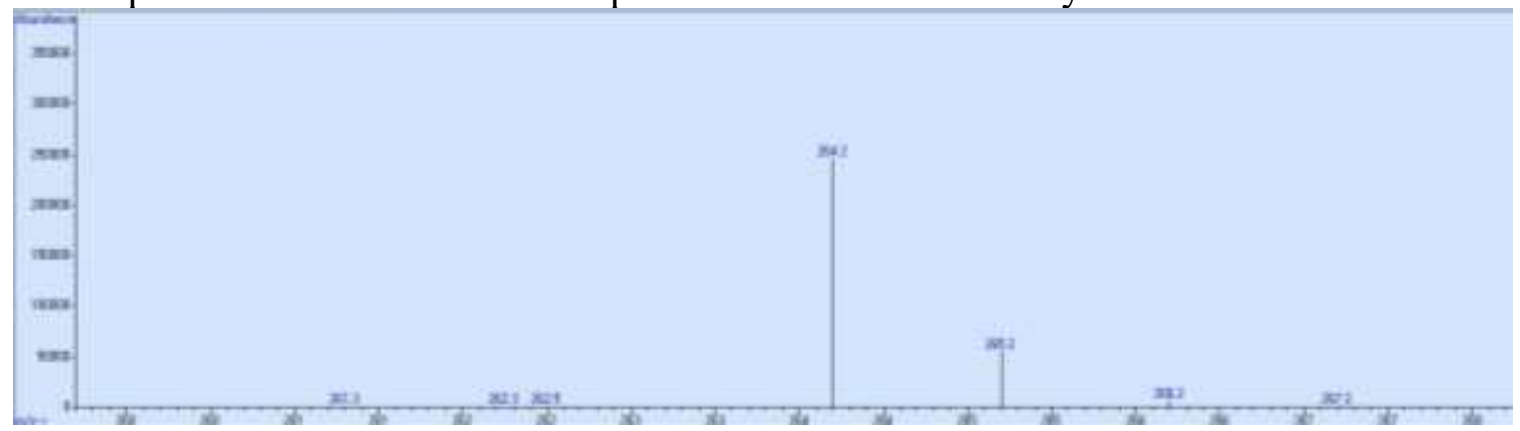

\begin{tabular}{|c|c|c|}
\hline $\mathrm{M} / \mathrm{Z}$ & Abundance & Relative $\% \mathrm{H}$ \\
\hline 263 & 0 & \\
\hline 264.2 & 245694 & 80.1 \\
\hline 265.2 & 55086 & 18.0 \\
\hline 266.2 & 6050 & 2.0 \\
\hline
\end{tabular}

Mass spectrum of the reaction with deuterated substrates at $20 \%$ yield

\begin{tabular}{|c|c|c|c|}
\hline 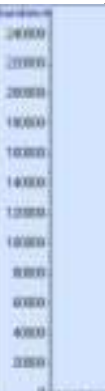 & & & \\
\hline $\mathrm{M} / \mathrm{Z}$ & Abundance & Relative $\%$ & $\% \mathrm{D}$ \\
\hline 263 & 0 & 0 & \\
\hline 264.2 & 3164 & 1.0 & \\
\hline 265.2 & 46620 & 15.1 & 7.4 \\
\hline 266.2 & 208012 & 67.5 & 64.1 \\
\hline 267.2 & 45402 & 14.7 & 14.4 \\
\hline 268.3 & 4955 & 1.6 & 1.6 \\
\hline
\end{tabular}

Total deuterium incorporation into product $=88 \%$

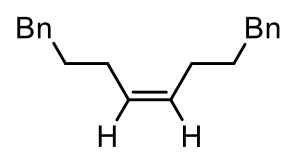

$\left[\mathrm{M}_{\mathrm{HH}}\right]$

$0 \% \mathrm{D}$

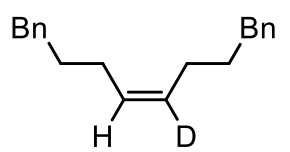

$\left[\mathrm{M}_{\mathrm{HD}}\right]$

$50 \% \mathrm{D}$

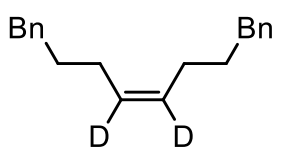

$\left[\mathrm{M}_{\mathrm{DD}}\right]$

$100 \% \mathrm{D}$ 
Since we are looking at the overall deuteration of two independent positions, we looked at the analysis from the perspective that a monodeuterated substrate, [MHD], would be $50 \%$ deuterated and a fully deuterated substrate, [MDD], would be $100 \%$ deuterated. This results in being able to think about $\% \mathrm{D}$ being the amount of fully deuterated molecules.

Since there is no $\left[\mathrm{MHн}_{\mathrm{H}}-1\right]^{+}$peak in the fully proteated substrate, the $\mathrm{M} / \mathrm{Z}=264.2$ peak in the experiment with deuterated reagents is assumed to be composed entirely of fully proteated substrate, $\left[\mathrm{MHH}^{+}\right.$. The $\mathrm{M} / \mathrm{Z}=265.2$ peak is assumed to be composed of $\left[\mathrm{MHH}^{+} 1\right]^{+}$and $[\mathrm{MHD}]^{+}$. Similarly, the $\mathrm{M} / \mathrm{Z}$ peak at 266.2 is assumed be composed of $\left[\mathrm{MHH}^{+2}\right]^{+},\left[\mathrm{MHD}^{+1}\right]^{+}$, and $[\mathrm{MDD}]^{+}$. The M/Z peak at 267.2 is assumed be composed of $\left[\mathrm{MHD}^{+2}\right]^{+}$, and $\left[\mathrm{MDD}^{+} 1\right]^{+}$. The peak at $\mathrm{M} / \mathrm{Z}=268.3$ is assumed to be composed entirely of $\left[\mathrm{MDD}^{+2}\right]^{+}$.

The contributions of $\left[\mathrm{MHH}^{+1}\right]^{+}$and $\left[\mathrm{MHH}^{+2}\right]^{+}$to the respective $[\mathrm{MHD}]^{+}$and $\left[\mathrm{MHD}^{+1}\right]^{+}$peaks were determined using the assumption that the ratios of $\left[\mathrm{MHH}^{+}\right.$to $\left[\mathrm{MHH}^{+1}\right]^{+}$and $\left[\mathrm{MHH}^{+2}\right]^{+}$would be the same in both the proteated and deuterated experiments. An additional assumption was made that the ratios of $\left[\mathrm{MHD}^{+}\right.$to $\left[\mathrm{MHD}^{+1}\right]^{+}$ and $\left[\mathrm{MHD}^{+} 2\right]^{+}$would match those of the $\left[\mathrm{MHH}^{+}\right.$. These ratios were then used to find and subtract out their expected contributions to subsequent peaks.

For example, the $\% \mathrm{D}$ in $\mathrm{M} / \mathrm{Z}=265.2$ was found using the following equation:

$$
\% \mathrm{D}_{265.2}=\left(\%_{265.2}-\%_{264.2} \times \frac{\% \mathrm{H}_{265.2}}{\% \mathrm{H}_{264.2}}\right) / 2
$$

The $\% \mathrm{D}$ in $\mathrm{M} / \mathrm{Z}=266.2$ was found using the following equation:

$$
{ }_{0} \mathrm{D}_{266.2}=\%_{266.2}-\left(\%_{264.2} \times \frac{\mathrm{OH}_{266.2}}{\% \mathrm{H}_{264.2}}\right)-\left(2 \times \% \mathrm{D}_{265.2} \times \frac{\% \mathrm{H}_{265.2}}{\% \mathrm{H}_{264.2}}\right)
$$

Mass spectrum of the reaction with proteated substrate at $41 \%$ yield

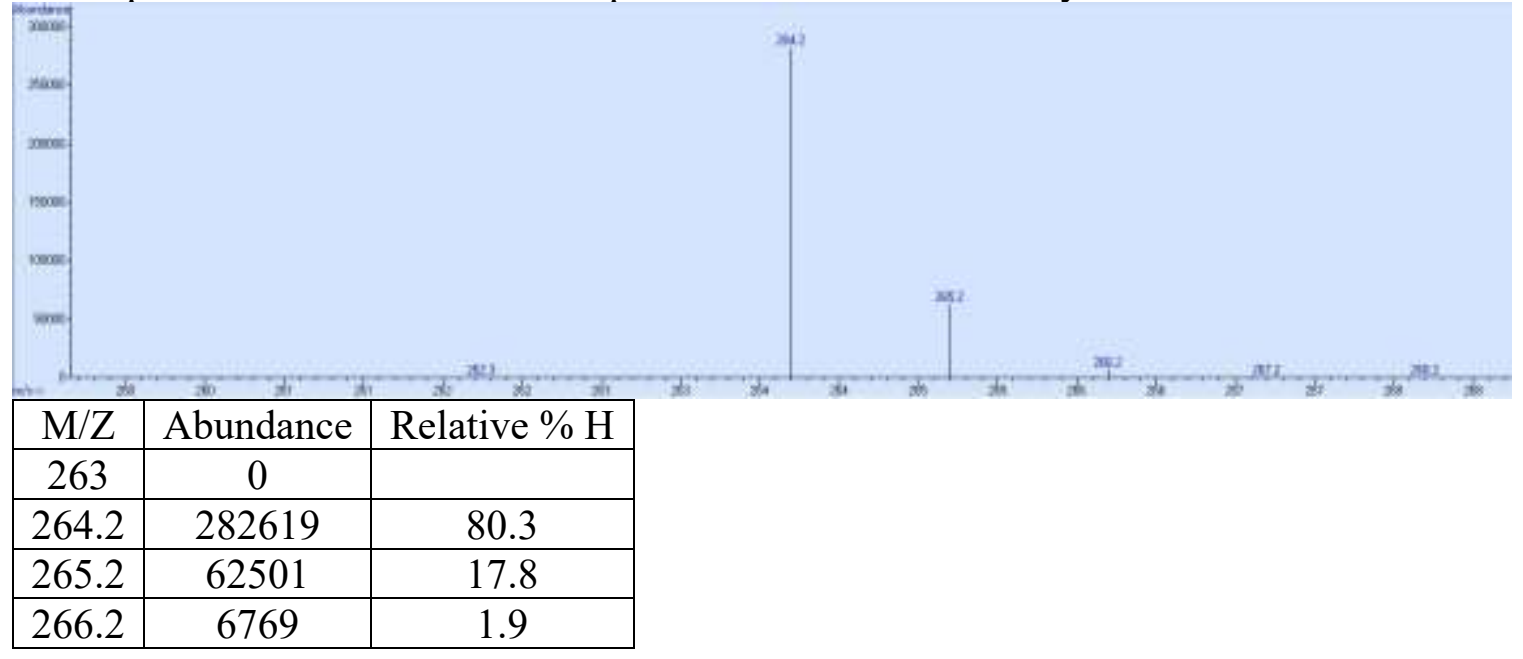


Mass spectrum of the reaction with deuterated substrates at $38 \%$ yield

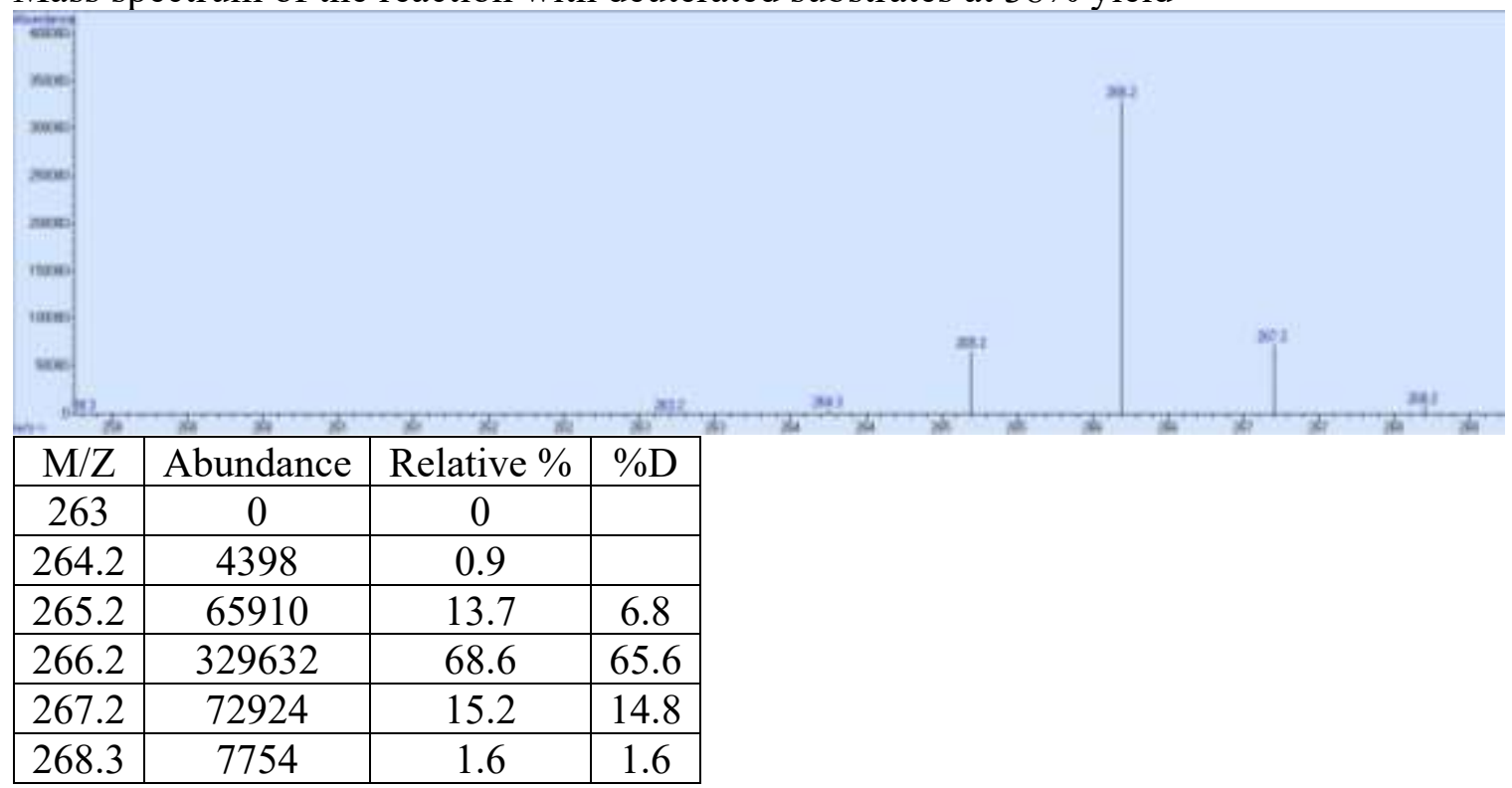

Total deuterium incorporation into product $=89 \%$

Mass spectrum of the reaction with proteated substrate at $69 \%$ yield

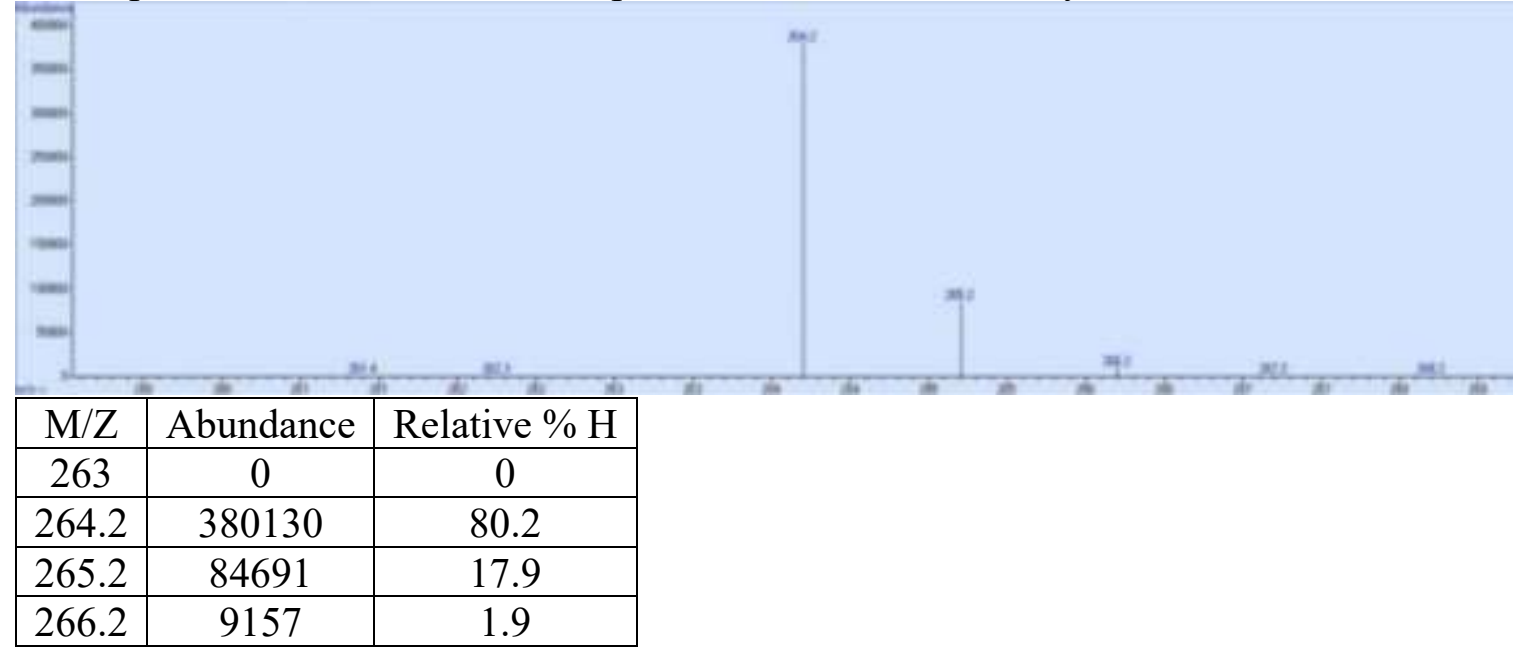

Mass spectrum of the reaction with deuterated substrates at $69 \%$ yield

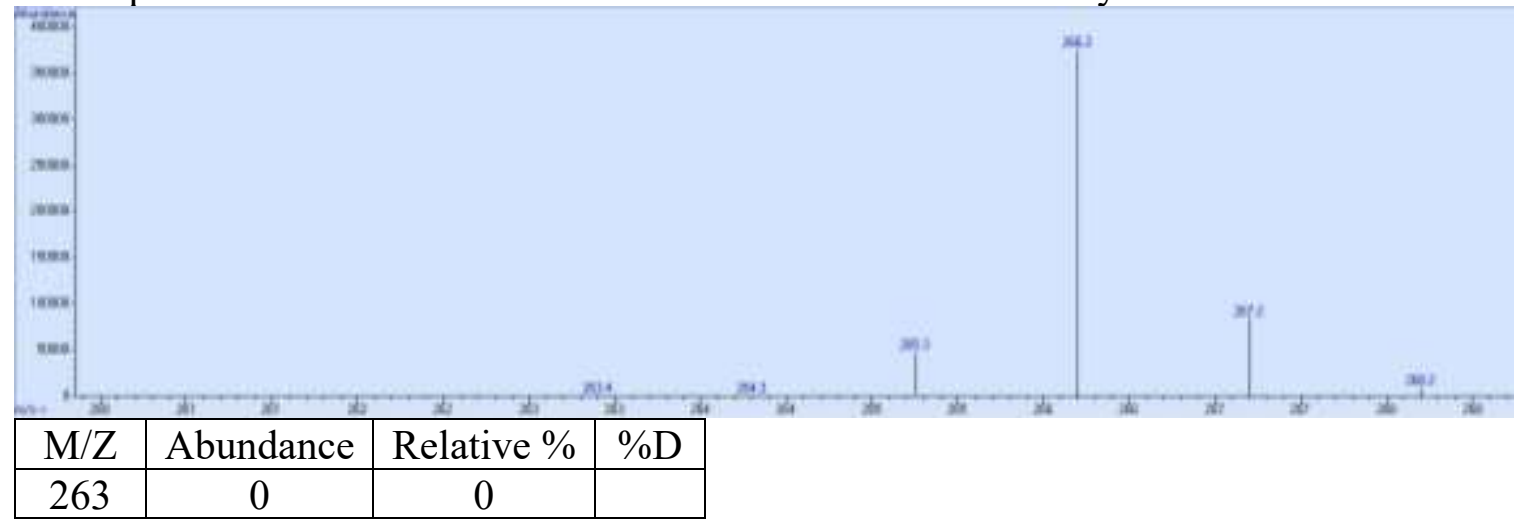




\begin{tabular}{|c|c|c|c|}
\hline 264.2 & 138 & 0.0 & \\
\hline 265.2 & 47096 & 9.2 & 4.6 \\
\hline 266.2 & 374221 & 72.8 & 70.8 \\
\hline 267.2 & 83573 & 16.3 & 16.0 \\
\hline 268.3 & 8905 & 1.7 & 1.7 \\
\hline
\end{tabular}

Total deuterium incorporation into product $=93 \%$

2.8.2 Competition Experiment with IPrAg Boronate complex

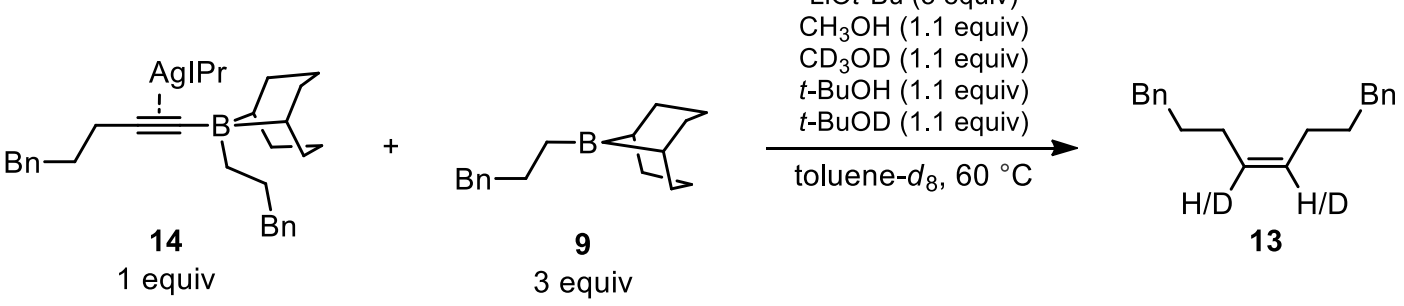

In a nitrogen filled glovebox, a 1-dram vial was charged with a stir bar and IPrAg boronate complex 14 (21.4 mg, $0.025 \mathrm{mmol}, 1$ equiv.). To this was added $\mathrm{LiO} t$-Bu (10.0 mg, 0.125 mmol, 5 equiv), $50 \mathrm{uL}$ of a $42.0 \mathrm{mg} / \mathrm{mL}$ solution of TMB (2.1 mg, $0.013 \mathrm{mmol}, 0.5$ equiv.) in toluene. This was followed by $100 \mathrm{uL}$ of a $180.0 \mathrm{mg} / \mathrm{mL}$ solution of alkyl borane $9(18.0$ $\mathrm{mg} 0.075 \mathrm{mmol}, 3.0$ equiv.) in toluene. Finally, $100 \mathrm{uL}$ of a solution containing $8.8 \mathrm{mg} / \mathrm{mL}$ $\mathrm{MeOH}$ (0.9 mg, $0.028 \mathrm{mmol}, 1.1$ equiv), $9.9 \mathrm{mg} / \mathrm{mL} \mathrm{CD}_{3} \mathrm{OD}$ (1.0 mg, $0.028 \mathrm{mmol}, 1.1$ equiv), $20.4 \mathrm{mg} / \mathrm{mL} t$-BuOH (2.0 mg, $0.028 \mathrm{mmol}, 1.1$ equiv), and $20.7 \mathrm{mg} / \mathrm{mL} t$-BuOD ( $2.1 \mathrm{mg}, 0.028 \mathrm{mmol}, 1.1$ equiv) in toluene was added. The reaction mixture was heated to $60^{\circ} \mathrm{C}$ and $25 \mathrm{uL}$ aliquots of the crude reaction mixtures were pushed through short plugs of silica with ethyl acetate and analyzed by GC/MS for deuterium incorporation.

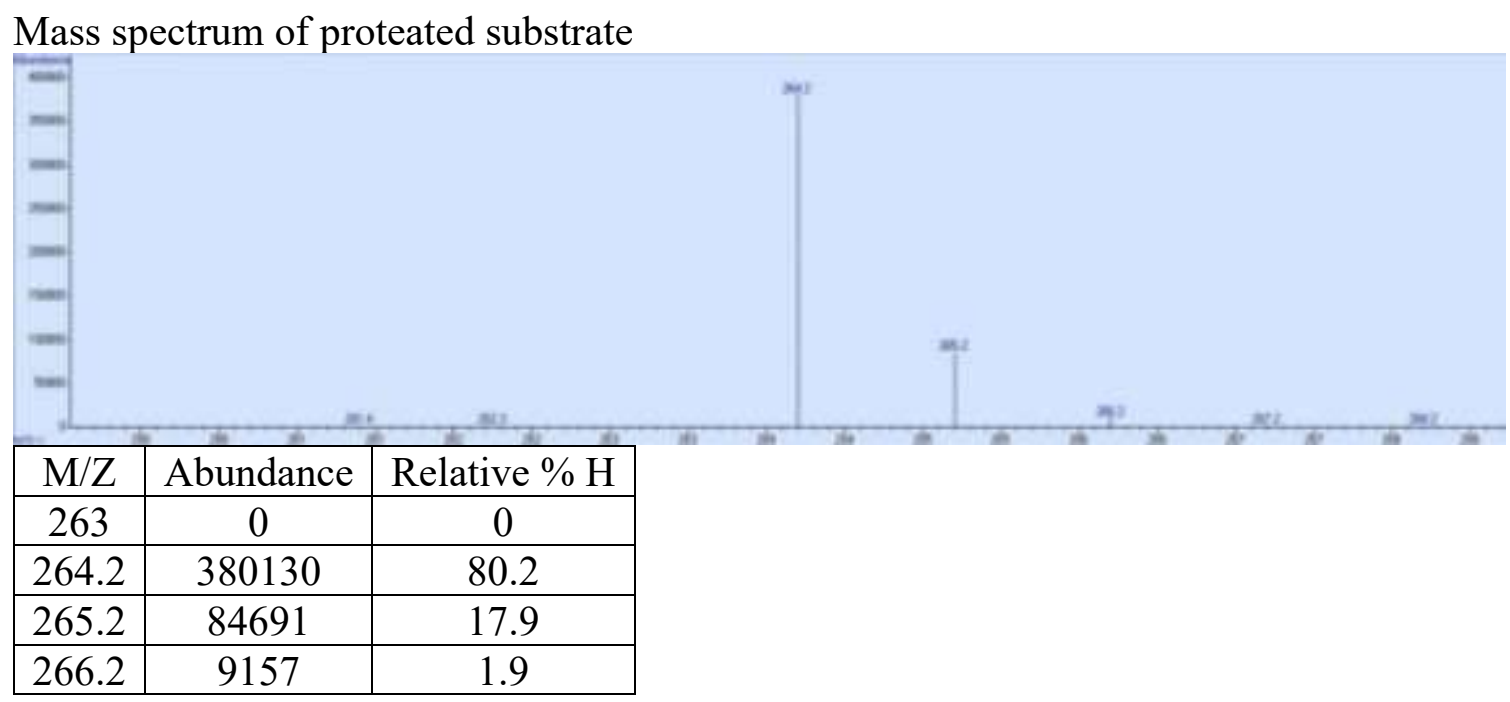


Mass spectrum of the competition experimment at $7 \%$ product formation

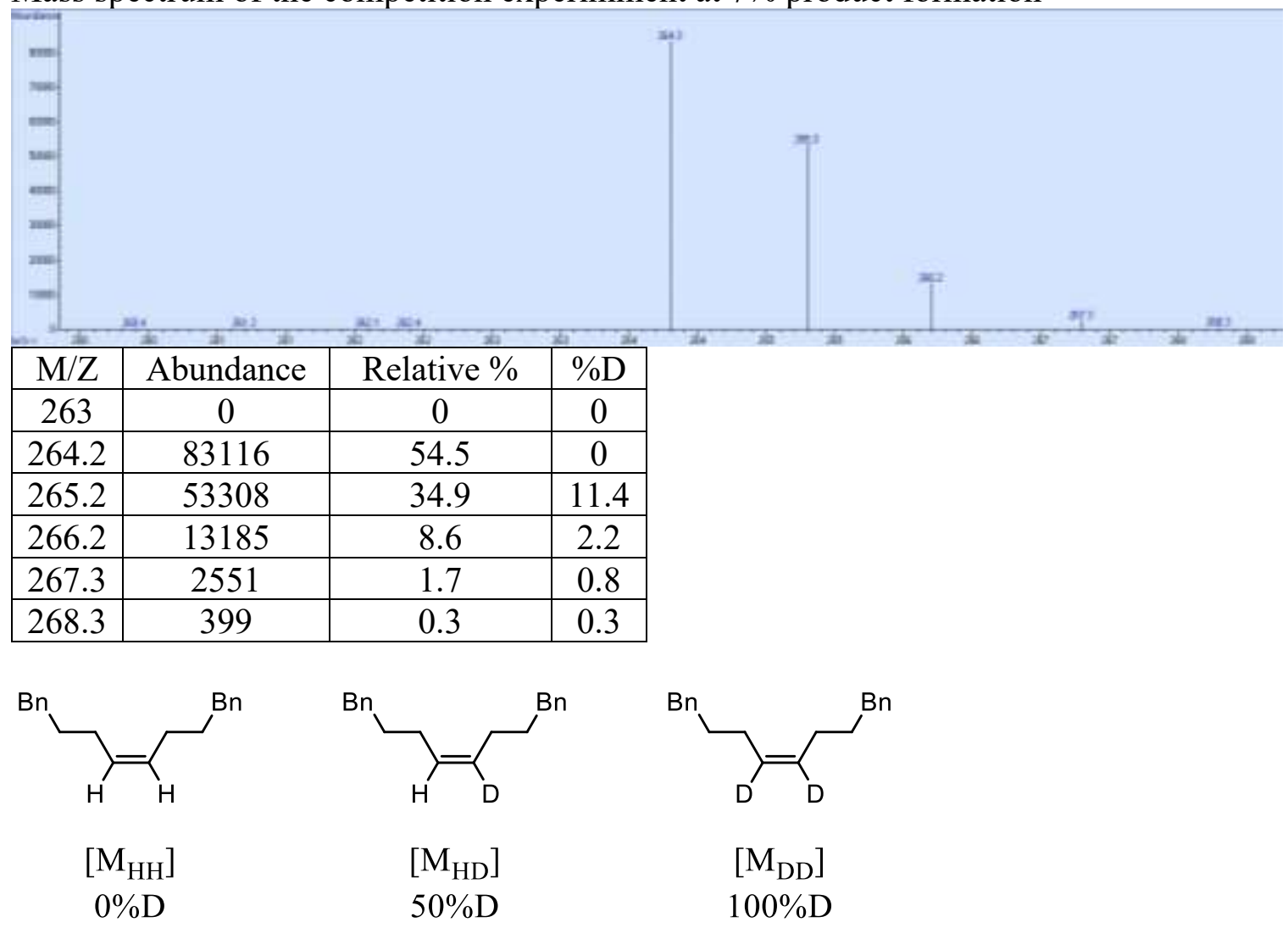

Since we are looking at the overall deuteration of two independent positions, we looked at the analysis from the perspective that a monodeuterated substrate, [MHD], would be $50 \%$ deuterated and a fully deuterated substrate, [MDD], would be $100 \%$ deuterated. This results in being able to think about $\% \mathrm{D}$ being the amount of fully deuterated molecules, which makes $100 \%-\% \mathrm{D}$ represent the amount of fully proteated molecules. Thus $K I E=\frac{100 \%-\% D}{\% D}$

Since there is no $\left[\mathrm{MHH}_{\mathrm{H}}-1\right]^{+}$peak in the fully proteated substrate, the $\mathrm{M} / \mathrm{Z}=264.2$ peak in the competition experiment is assumed to be composed entirely of fully proteated substrate, $\left[\mathrm{MHH}^{+}\right.$. The $\mathrm{M} / \mathrm{Z}=265.2$ peak in the competition experiment is assumed to be composed of $\left[\mathrm{MHH}^{+1}\right]^{+}$and $[\mathrm{MHD}]^{+}$. Similarly, the $\mathrm{M} / \mathrm{Z}$ peak at 266.2 is assumed be composed of $\left[\mathrm{MHH}^{+} 2\right]^{+},\left[\mathrm{MHD}^{+1}\right]^{+}$, and $[\mathrm{MDD}]^{+}$. The $\mathrm{M} / \mathrm{Z}$ peak at 267.2 is assumed be composed of $\left[\mathrm{MHD}_{\mathrm{HD}}+2\right]^{+}$, and $\left[\mathrm{MDD}^{+} 1\right]^{+}$. The peak at $\mathrm{M} / \mathrm{Z}=268.3$ is assumed to be composed entirely of $\left[\mathrm{MDD}^{+} 2\right]^{+}$.

The contributions of $\left[\mathrm{MHH}_{\mathrm{HH}}+1\right]^{+}$and $\left[\mathrm{MHH}_{\mathrm{H}}+2\right]^{+}$to the respective $[\mathrm{MHD}]^{+},\left[\mathrm{MHD}_{\mathrm{HD}}^{+1}\right]^{+}$, and $[\mathrm{MDD}]^{+}$peaks were determined using the assumption that the ratios of $\left[\mathrm{MHH}^{+}\right.$to $\left[\mathrm{MHH}^{+} 1\right]^{+}$and $\left[\mathrm{MHH}^{+} 2\right]^{+}$would be the same in both experiments. An additional assumption was made that the ratios of $[\mathrm{MHD}]^{+}$to $\left[\mathrm{MHD}^{+1}\right]^{+}$and $[\mathrm{MHD}+2]^{+}$would match those of the $[\mathrm{MHH}]^{+}$. These ratios were then used to find and subtract out their expected contributions to subsequent peaks.

For example, the $\% \mathrm{D}$ in $\mathrm{M} / \mathrm{Z}=265.2$ was found using the following equation: 


$$
\% \mathrm{D}_{265.2}=\left(\%_{265.2}-\%_{264.2} \times \frac{\% \mathrm{H}_{265.2}}{\% \mathrm{H}_{264.2}}\right) / 2
$$

The $\% \mathrm{D}$ in $\mathrm{M} / \mathrm{Z}=266.2$ was found using the following equation:

$$
{ }_{0} \mathrm{D}_{266.2}=\%_{266.2}-\left(\%_{264.2} \times \frac{\mathrm{HH}_{266.2}}{\% \mathrm{H}_{264.2}}\right)-\left(2 \times \% \mathrm{D}_{265.2} \times \frac{\% \mathrm{H}_{265.2}}{\% \mathrm{H}_{264.2}}\right)
$$

Overall: $K I E=\frac{85.3 \%}{14.7 \%}=5.8$

This value represents the average of the two separate KIE effects for the two protonation events.

2.8.3 Competition Experiment for Protodeargentation
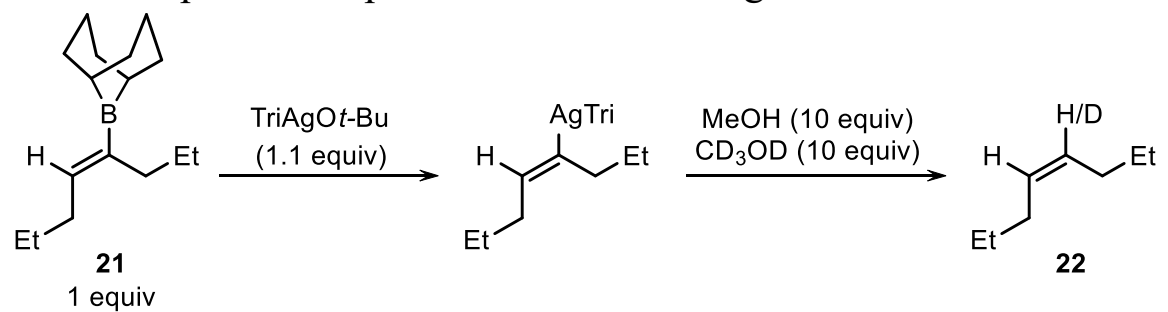

In a nitrogen filled glovebox, a 1-dram vial was charged with a stir bar and TriAgOt-Bu (106.7 mg, $0.165 \mathrm{mmol}, 1.1$ equiv.). To this was added TMB (12.6 mg, $0.075 \mathrm{mmol}, 0.5$ equiv.) using $3 \times 250 \mathrm{uL} \mathrm{C}_{6} \mathrm{D}_{6}$. This was followed by octenyl borane $21(34.8 \mathrm{mg} 0.15 \mathrm{mmol}$, 1.0 equiv.) using $3 \times 300 \mathrm{uL} \mathrm{C}_{6} \mathrm{D}_{6}$. After stirring for $10 \mathrm{~min}, 450 \mathrm{uL}$ of this solution was transferred to an NMR tube and used to confirm complete transmetalation. Another 500 $\mathrm{uL}$ was added to a $100 \mathrm{uL}$ solution containing $\mathrm{MeOH}(48.1 \mathrm{mg}, 1.5 \mathrm{mmol}, 10$ equiv) and $\mathrm{CD}_{3} \mathrm{OD}$ (54.1 mg, $1.5 \mathrm{mmol}, 10$ equiv) in $\mathrm{C}_{6} \mathrm{D}_{6}$. This was then added to an NMR tube to confirm complete protodeargentation. Similarly, another $500 \mathrm{uL}$ was added to a $100 \mathrm{uL}$ solution of $\mathrm{MeOH}\left(96.1 \mathrm{mg}, 3.0 \mathrm{mmol}, 20\right.$ equiv) in $\mathrm{C}_{6} \mathrm{D}_{6}$ and protodeargentation was checked by NMR. 25 uL aliquots of the competition experiment and control experiment were pushed through short plugs of silica with ethyl acetate and analyzed by GC/MS to determine deuterium incorporation.

Mass spectrum of the control experiment

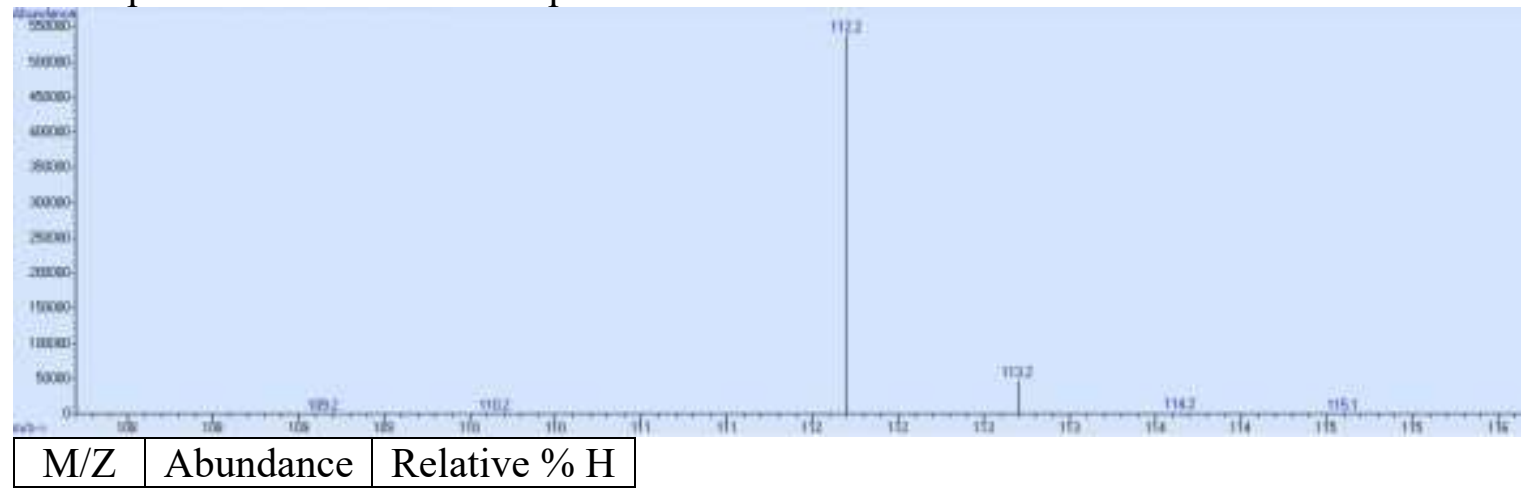




\begin{tabular}{|c|c|c|}
\hline 111 & 0 & 0 \\
\hline 112.2 & 537845 & 91.7 \\
\hline 113.2 & 46705 & 8.0 \\
\hline 114.2 & 1918 & 0.3 \\
\hline
\end{tabular}

Mass spectrum of the competition experiment

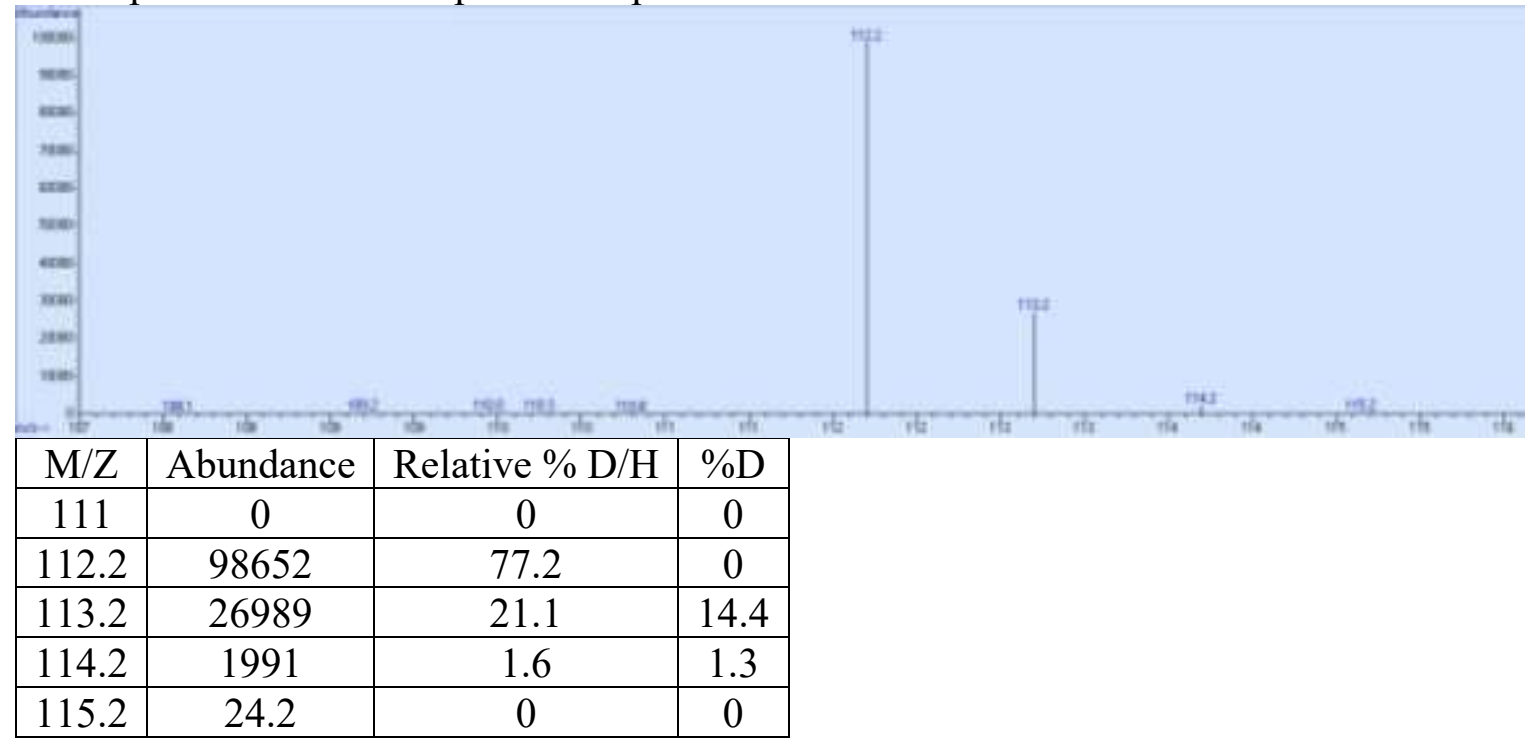

Calculation of Deuterium Incorporation

Since there is no $\left[\mathrm{MH}_{-}-1\right]^{+}$peak in the control, the $\mathrm{M} / \mathrm{Z}=112.2$ peak in the competition experiment is assumed to be composed entirely of fully proteated substrate, $\left[\mathrm{MH}_{\mathrm{H}}\right]^{+}$. The $\mathrm{M} / \mathrm{Z}=113.2$ peak in the competition experiment is assumed to be composed of $\left[\mathrm{MH}^{+}+1\right]^{+}$ and $\left[\mathrm{M}_{\mathrm{D}}\right]^{+}$. Similarly, the $\mathrm{M} / \mathrm{Z}$ peak at 114.2 is assumed be composed of $\left[\mathrm{M}_{\mathrm{H}}+2\right]^{+}$and $\left[\mathrm{M}_{\mathrm{D}}+1\right]^{+}$. The peak at $\mathrm{M} / \mathrm{Z}=115.2$ is assumed to be composed entirely of $\left[\mathrm{M}_{\mathrm{D}}+2\right]^{+}$.

The contributions of $\left[\mathrm{MH}_{\mathrm{H}}+1\right]^{+}$and $\left[\mathrm{MH}_{\mathrm{H}}+2\right]^{+}$to the respective $\left[\mathrm{MD}^{+}\right.$and $\left[\mathrm{MD}_{\mathrm{D}}+1\right]^{+}$ peaks were determined using the assumption that the ratios of $\left[\mathrm{MH}^{+}\right.$to $\left[\mathrm{MH}_{\mathrm{H}}+1\right]^{+}$and $\left[\mathrm{MH}^{+} 2\right]^{+}$would be the same in both experiments. These ratios were then used to find and subtract out the expected contribution from proteated substrates.

For example, the $\% \mathrm{D}$ in $\mathrm{M} / \mathrm{Z}=113.2$ was found using the following equation:

$$
\% \mathrm{D}_{113.2}=\% \mathrm{D} / \mathrm{H}_{113.2}-\% \mathrm{D} / \mathrm{H}_{112.2}\left(\frac{\% \mathrm{H}_{113.2}}{\% \mathrm{H}_{112.2}}\right)
$$

Overall: $K I E=\frac{84.3 \%}{15.7 \%}=5.3$ 


\subsection{Resting State NMR Experiment}

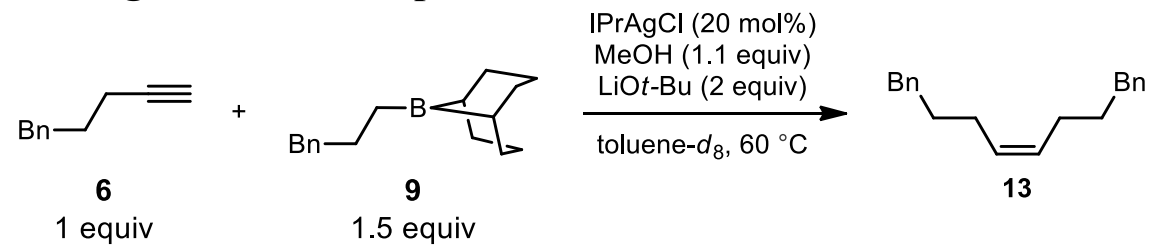

In a nitrogen filled glovebox, a 1-dram vial was charged with a stir bar and $\mathrm{IPrAgCl}$ catalyst (10.6 mg, $0.02 \mathrm{mmol}, 0.20$ equiv). To this was added $\mathrm{LiO} t$-Bu (16.0 mg, $0.2 \mathrm{mmol}, 2.0$ equiv) and $500 \mathrm{uL}$ toluene- $d_{8}$. To this was added $100 \mathrm{uL}$ of a stock solution of $144.2 \mathrm{mg} / \mathrm{mL}$ alkyne 6 (14.4 mg, $0.10 \mathrm{mmol}, 1.0$ equiv) and $84.1 \mathrm{mg} / \mathrm{mL}$ TMB ( $8.4 \mathrm{mg}, 0.05 \mathrm{mmol}, 0.5$ equiv) in toluene- $d 8$, alkylborane 9 (36.0 $\mathrm{mg}, 0.15 \mathrm{mmol}, 1.5$ equiv) using $3 \times 100 \mathrm{uL}$ toluene- $d 8$, and $100 \mathrm{uL}$ of a solution of $35.2 \mathrm{mg} / \mathrm{mL}$ methanol $(3.5 \mathrm{mg}, 0.11 \mathrm{mmol}, 1.10$ equiv) in toluene- $d 8$. After stirring for 2 hours at $60{ }^{\circ} \mathrm{C}$, an aliquot for $\mathrm{GC}$ analysis was taken and $500 \mathrm{uL}$ (half) of the reaction was added to a J-Young tube. The J-Young tube was then placed in a preheated $\left(60{ }^{\circ} \mathrm{C}\right)$ NMR spectrometer and allowed to reach temperature for 5 minutes. A spectrum was then acquired. Several subsequent NMR spectra were taken to ensure the reaction was progressing in the J-Young tube. The JYoung tube was later returned to the glovebox and $25 \mathrm{uL}$ aliquots of it and the other half that remained stirring in the glovebox were pushed through short plugs of silica with ethyl acetate and analyzed by GC to ensure equivalency.

\subsection{Variable Temperature NMR Experiments}

\subsubsection{IPrAg Complex 14}

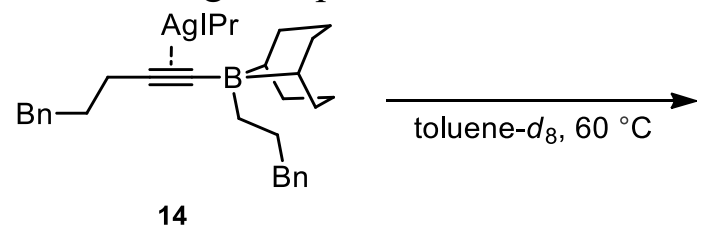

In a nitrogen filled glovebox, a 1-dram vial was charged with IPrAg complex 14 (8.8 mg, $0.01 \mathrm{mmol}, 1.0$ equiv) (amount at $20 \%$ catalyst loading in reaction) and $500 \mathrm{uL}$ toluene- $d_{8}$ was used to transfer it to a J-Young tube. The J-Young tube was then placed in a preheated $\left(60{ }^{\circ} \mathrm{C}\right) \mathrm{NMR}$ spectrometer and allowed to reach temperature for 5 minutes. A spectrum was then acquired.

2.10.2 IPrAg Complex 14 and alkyl borane 9
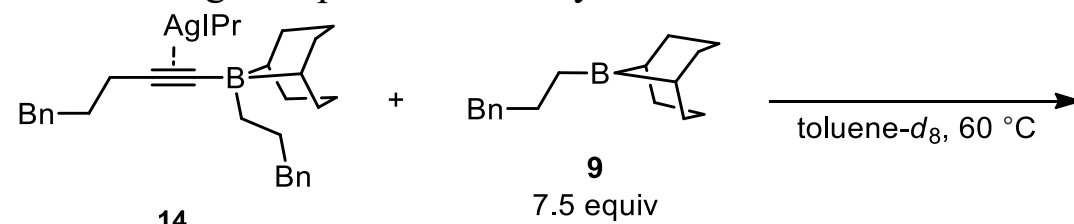

In a nitrogen filled glovebox, a 1-dram vial was charged with IPrAg complex 14 (8.8 mg, $0.01 \mathrm{mmol}, 1.0$ equiv) (amount at $20 \%$ catalyst loading in reaction) and $200 \mathrm{uL}$ toluene- $d 8$. To this was added alkylborane $9(18.0 \mathrm{mg}, 0.075 \mathrm{mmol}, 7.5$ equiv) using $3 \times 100 \mathrm{uL}$ toluene$d_{8}$. The solution was then transferred to a J-Young tube and an NMR spectrum at $25{ }^{\circ} \mathrm{C}$ was acquired. The J-Young tube was then removed while the NMR spectrometer was 
heated to $60{ }^{\circ} \mathrm{C}$ at which point the J-Young tube was re-inserted and allowed to reach temperature for 5 minutes. A spectrum was then acquired.

\subsection{Alkyl Borane Crossover Experiment}

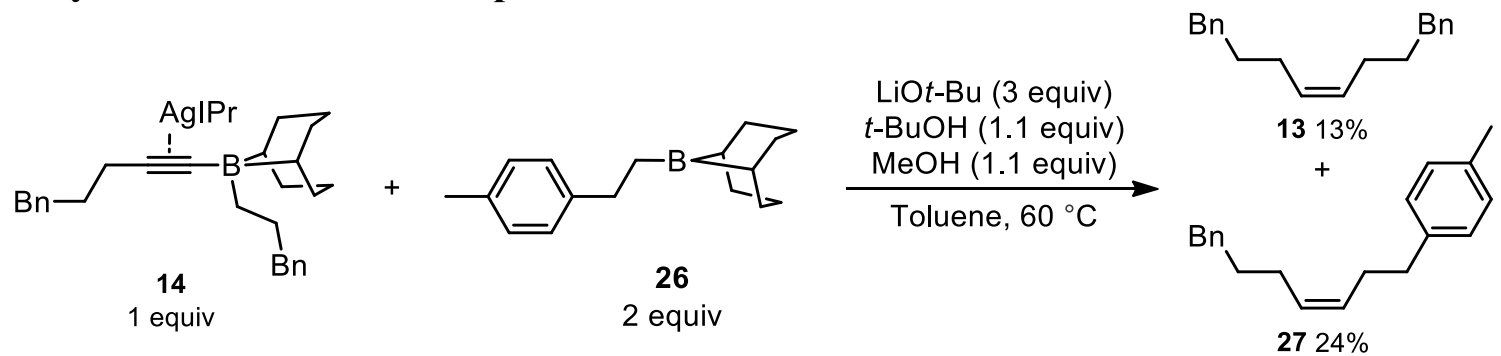

In a nitrogen filled glovebox, a 1-dram vial was charged with a stir bar and IPrAg boronate complex 14 (21.4 mg, $0.025 \mathrm{mmol}, 1$ equiv.). To this was added $\mathrm{LiO} t$-Bu (6.0 $\mathrm{mg}, 0.075$ mmol, 3 equiv), $50 \mathrm{uL}$ of a $42.0 \mathrm{mg} / \mathrm{mL}$ solution of TMB $(2.1 \mathrm{mg}, 0.013 \mathrm{mmol}, 0.5$ equiv.) in toluene. This was followed by $100 \mathrm{uL}$ of a $120.0 \mathrm{mg} / \mathrm{mL}$ solution of alkyl borane 26 (12.0 mg $0.050 \mathrm{mmol}, 2.0$ equiv.) in toluene. Finally, $100 \mathrm{uL}$ of a solution containing 8.8 $\mathrm{mg} / \mathrm{mL} \mathrm{MeOH} \mathrm{(0.9} \mathrm{mg,} 0.028 \mathrm{mmol}, 1.1$ equiv) and $20.4 \mathrm{mg} / \mathrm{mL} t$-BuOH $(2.0 \mathrm{mg}, 0.028$ mmol, 1.1 equiv) in toluene was added. The reaction mixture was heated to $60{ }^{\circ} \mathrm{C}$. A 25 $\mathrm{uL}$ aliquot of the crude reaction mixture was pushed through a short plug of silica with ethyl acetate and analyzed by GC.

\section{Characterization of Organic Reagents and Products}

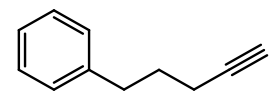

Pent-4-yn-1-ylbenzene (6) was purchased from GFS Chemical and distilled over calcium hydride under reduced pressure before use.<smiles>[2H]C#CCCCc1ccccc1</smiles>

Pent-4-yn-1-ylbenzene (6-D) was prepared according to a known procedure and has been previously characterized ${ }^{1}$. Deuterium incorporation was $95 \%$ (NMR).<smiles></smiles>

9-(3-phenylpropyl)-9-borabicyclo[3.3.1]nonane (9) was prepared according to a known procedure. $^{2}$<smiles>C#CCCCOc1ccc(C(=O)OC)cc1</smiles>

Methyl 4-(pent-4-yn-1-yloxy)benzoate (10) was prepared according to a known procedure and has been previously characterized. ${ }^{2}$ 
<smiles>COC(=O)c1ccc(OCCC/C=C\CCCc2ccccc2)cc1</smiles>

(Z)-methyl 4-((8-phenyloct-4-en-1-yl)oxy)benzoate (S1) was prepared according to a known procedure and has been previously characterized. ${ }^{2}$

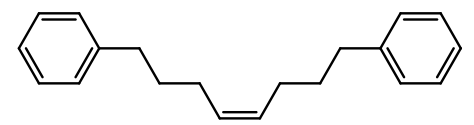

(Z)-1,8-diphenyloct-4-ene (13) was prepared according to a known procedure and has been previously characterized. $^{2}$

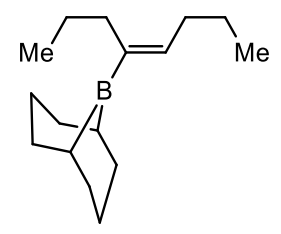

9-((Z)-Oct-4-en-4-yl)-9-borabicyclo[3.3.1]nonane (21) was prepared according to a known procedure and has been previously characterized. ${ }^{3}$

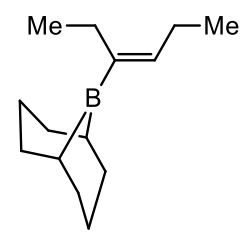

9-((Z)-hex-3-en-3-yl)-9-borabicyclo[3.3.1]nonane (23) was prepared according to a known procedure and has been previously characterized. ${ }^{4}$<smiles>CCCC1CCCC1[B]CCc1ccc(C)cc1</smiles>

9-(4-methylphenethyl)-9-borabicyclo[3.3.1]nonane (26) was prepared according to a known procedure. $^{2}$

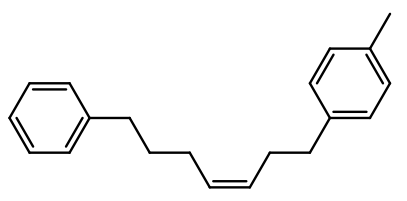

((Z)-1-methyl-4-(7-phenylhept-3-en-1-yl)benzene (27) was prepared according to a known procedure and has been previously characterized. ${ }^{2}$ 


\section{Synthesis and Characterization of TriAg and IPrAg Complexes}<smiles>CNC(=O)C1N(c2c(C(C)C)cccc2C(C)C)N=C(c2ccccc2C(C)C)N1c1c(C(C)C)cccc1C(C)C</smiles>

TriAgCl was prepared according to a known procedure and has been previously characterized. ${ }^{2}$<smiles>CC(C)c1cccc(C(C)C)c1N1C=CN(c2c(C(C)C)cccc2C(C)C)C1C(=O)Cl</smiles>

IPrAgCI was prepared according to a known procedure and has been previously characterized. ${ }^{5}$<smiles>CC(C)c1ccccc1C1=NN(c2c(C(C)C)cccc2C(C)C)C(C(C)C)N1c1c(C(C)C)cccc1C(C)C</smiles>

TriAgEt Complex (5) was synthesized following the same procedure used by Sadighi et al. for the synthesis of SIPrAgEt by using TriAgOt-Bu instead of SIPrAgOt-Bu. ${ }^{6}{ }^{1} \mathrm{H}$ NMR (500 MHz, $\left.\mathrm{C}_{6} \mathrm{D}_{6}\right) \delta 7.52(\mathrm{~d}, J=7.9 \mathrm{~Hz}, 2 \mathrm{H}), 7.26(\mathrm{t}, J=7.8 \mathrm{~Hz}, 1 \mathrm{H}), 7.20(\mathrm{t}, J=7.8 \mathrm{~Hz}, 1 \mathrm{H}), 7.14(\mathrm{~d}, J=7.8$ $\mathrm{Hz}, 2 \mathrm{H}), 7.05(\mathrm{~d}, J=7.8 \mathrm{~Hz}, 2 \mathrm{H}), 6.84(\mathrm{t}, J=7.4 \mathrm{~Hz}, 1 \mathrm{H}), 6.76(\mathrm{t}, J=7.7 \mathrm{~Hz}, 2 \mathrm{H}), 2.95$ (hept, $J=$ $6.8 \mathrm{~Hz}, 2 \mathrm{H}), 2.74$ (hept, $J=6.6 \mathrm{~Hz}, 2 \mathrm{H}), 1.82$ (dt, $J=11.7,8.0 \mathrm{~Hz}, 3 \mathrm{H}), 1.52-1.41$ (m, 12H), $1.20(\mathrm{~d}, J=6.9 \mathrm{~Hz}, 6 \mathrm{H}), 0.97(\mathrm{dq}, J=12.5,8.0 \mathrm{~Hz}, 2 \mathrm{H}), 0.88(\mathrm{~d}, J=6.9 \mathrm{~Hz}, 6 \mathrm{H})$.<smiles>CC(C)c1cccc(C(F)F)c1N1C=CN(c2c(C(F)(F)F)cccc2C(F)(F)F)C1N(C)CC#CCCBr</smiles>

IPrAg Acetylide Complex (12) In a nitrogen filled glovebox, a scintillation vial was charged with a stir bar and $\mathrm{IPrAgCl}(550 \mathrm{mg}, 1.04 \mathrm{mmol}, 1.0$ equiv). To this was added $\mathrm{NaOt}-\mathrm{Bu}(109.9 \mathrm{mg}$ $0.144 \mathrm{mmol}, 1.1$ equiv), alkyne $6(225.0 \mathrm{mg} 1.560 \mathrm{mmol}, 1.5$ equiv) and toluene (10 mL). The reaction mixture was stirred at $25^{\circ} \mathrm{C}$ for 2 hours. After, 2 hours, the reaction mixture was filtered through a plug of celite and concentrated. The silver acetylide was then precipitated out with pentane, collected by vacuum filtration and washed several times with pentane. The product was isolated as a white powder (626.5 mg, 94\% yield). ${ }^{1} \mathrm{H}$ NMR (300 MHz, $\left.\mathrm{C}_{6} \mathrm{D}_{6}\right) \delta 7.21-7.17$ (m, 
2H), $7.14-6.94(\mathrm{~m}, 9 \mathrm{H}), 6.28(\mathrm{~s}, 2 \mathrm{H}), 2.67(\mathrm{t}, J=7.6 \mathrm{~Hz}, 2 \mathrm{H}), 2.60-2.39(\mathrm{~m}, 4 \mathrm{H}), 2.30(\mathrm{t}, J=$ $6.6 \mathrm{~Hz}, 2 \mathrm{H}), 1.83-1.62(\mathrm{~m}, 2 \mathrm{H}), 1.32(\mathrm{~d}, J=6.8 \mathrm{~Hz}, 12 \mathrm{H}), 1.03(\mathrm{~d}, J=6.8 \mathrm{~Hz}, 12 \mathrm{H}) .{ }^{13} \mathrm{C}$ NMR $\left(126 \mathrm{MHz}, \mathrm{CDCl}_{3}\right) \delta 188.0(\mathrm{~d}, J=192.1 \mathrm{~Hz}), 188.0(\mathrm{~d}, J=165.4 \mathrm{~Hz}), 145.6,142.7,134.9,130.4$, 128.6, 128.0, 125.3, 124.2, 123.4, 123.4, 107.2 (d, $J=224.1 \mathrm{~Hz}), 107.2(\mathrm{~d}, J=194.1 \mathrm{~Hz}), 106.9$ (d, $J=57.0 \mathrm{~Hz}), 35.1,32.0,28.7,24.7,24.0,20.3,20.2$.

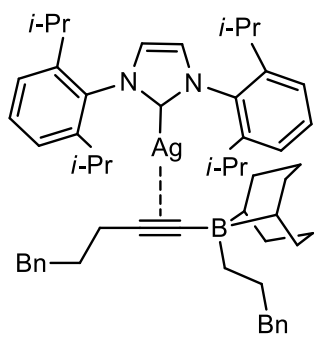

IPrAg Boronate Complex (14) In a nitrogen filled glovebox, a scintillation vial was charged with a stir bar and silver acetylide 12 (223.9 $\mathrm{mg}, 0.350 \mathrm{mmol}, 1.0$ equiv). To this was added alkylborane 9 (92.5 $\mathrm{mg} 0.385 \mathrm{mmol}, 1.1$ equiv) and toluene $(3.5 \mathrm{~mL})$. The reaction mixture was stirred at 25 ${ }^{\circ} \mathrm{C}$ for 1 hour. After 1 hour, the solvent was removed under vacuum and the boronate complex was precipitated out with pentane. It was then collected by vacuum filtration and washed several times with pentane. The complex was isolated as an off-white powder $(282.8 \mathrm{mg}, 92 \%$ yield $) .{ }^{1} \mathrm{H}$ NMR $\left(300 \mathrm{MHz}, \mathrm{C}_{6} \mathrm{D}_{6}\right) \delta 7.37(\mathrm{~d}, \mathrm{~J}=7.4 \mathrm{~Hz}, 2 \mathrm{H}), 7.28-7.17(\mathrm{~m}, 5 \mathrm{H}), 7.14-7.05(\mathrm{~m}, 5 \mathrm{H}), 7.02(\mathrm{~d}, \mathrm{~J}$ $=7.7 \mathrm{~Hz}, 4 \mathrm{H}), 6.31(\mathrm{~s}, 2 \mathrm{H}), 2.96-2.81(\mathrm{~m}, 2 \mathrm{H}), 2.57-2.24(\mathrm{~m}, 12 \mathrm{H}), 2.13-1.91(\mathrm{~m}, 8 \mathrm{H}), 1.85$ $-1.72(\mathrm{~m}, 2 \mathrm{H}), 1.36-1.21(\mathrm{~m}, 14 \mathrm{H}), 1.01(\mathrm{~d}, \mathrm{~J}=6.8 \mathrm{~Hz}, 12 \mathrm{H}), 0.70(\mathrm{~s}, 4 \mathrm{H})$.

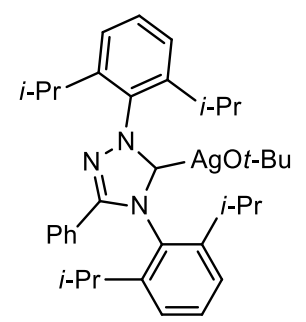

TriAgOt-Bu (S2) was synthesized following the same procedure used by Sadighi et al. for the

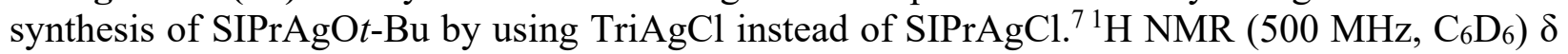
$7.49(\mathrm{~d}, J=7.8 \mathrm{~Hz}, 2 \mathrm{H}), 7.28(\mathrm{t}, J=7.8 \mathrm{~Hz}, 1 \mathrm{H}), 7.21(\mathrm{t}, J=7.8 \mathrm{~Hz}, 1 \mathrm{H}), 7.12(\mathrm{~d}, J=7.7 \mathrm{~Hz}, 2 \mathrm{H})$, $7.02(\mathrm{~d}, J=7.8 \mathrm{~Hz}, 2 \mathrm{H}), 6.83(\mathrm{t}, J=7.4 \mathrm{~Hz}, 1 \mathrm{H}), 6.74(\mathrm{t}, J=7.7 \mathrm{~Hz}, 2 \mathrm{H}), 2.90-2.79(\mathrm{~m}, 2 \mathrm{H})$, $2.71-2.56(\mathrm{~m}, 2 \mathrm{H}), 1.47(\mathrm{~s}, 9 \mathrm{H}), 1.37(\mathrm{~d}, J=6.9 \mathrm{~Hz}, 6 \mathrm{H}), 1.33(\mathrm{~d}, J=6.9 \mathrm{~Hz}, 6 \mathrm{H}), 1.16(\mathrm{~d}, J=$ $6.9 \mathrm{~Hz}, 6 \mathrm{H}), 0.82(\mathrm{~d}, J=6.9 \mathrm{~Hz}, 6 \mathrm{H}) .{ }^{13} \mathrm{C} \mathrm{NMR}\left(126 \mathrm{MHz}, \mathrm{C}_{6} \mathrm{D}_{6}\right) \delta 190.0(\mathrm{~d}, J=193.1 \mathrm{~Hz}), 190.0$ $(\mathrm{d}, J=221.2 \mathrm{~Hz}), 153.5,153.4,146.1,145.5,135.9,132.7,131.7,131.4,131.3,129.1,128.1$, $125.3,125.3,124.5,69.3,37.9,29.4,24.9,24.4,24.0,22.9$. 


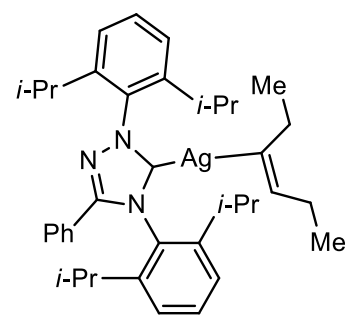

TriAg Hexenyl Complex (24) In a nitrogen filled glovebox, a 1-dram vial was charged with a stir bar and TriAgOt-Bu (100 mg, $0.154 \mathrm{mmol}, 1.1$ equiv.). To this was added $1.1 \mathrm{ml}$ toluene and hexenyl borane 23 (28.6 mg $0.14 \mathrm{mmol}, 1.0$ equiv.) using 3x300 uL toluene. Reaction was stirred for $30 \mathrm{~min}$ at $25^{\circ} \mathrm{C}$ and then most $(\sim 1 \mathrm{~mL})$ of the toluene was removed without heating under reduced pressure. Pentane was then added and the solution was put in the freezer to encourage precipitation of the product. The precipitate was collected by vacuum filtration and washed with cold pentane. ${ }^{1} \mathrm{H}$ NMR $\left(300 \mathrm{MHz}, \mathrm{C}_{6} \mathrm{D}_{6}\right) \delta 7.52(\mathrm{~d}, J=7.3 \mathrm{~Hz}, 2 \mathrm{H}), 7.31-7.19(\mathrm{~m}, 2 \mathrm{H}), 7.13-$ $7.00(\mathrm{~m}, 4 \mathrm{H}), 6.84-6.69(\mathrm{~m}, 3 \mathrm{H}), 5.71-5.56(\mathrm{~m}, 1 \mathrm{H}), 3.02-2.85(\mathrm{~m}, 2 \mathrm{H}), 2.80-2.65(\mathrm{~m}, 2 \mathrm{H})$, $2.60-2.44(\mathrm{~m}, 2 \mathrm{H}), 2.44-2.28(\mathrm{~m}, 2 \mathrm{H}), 1.53-1.33(\mathrm{~m}, 12 \mathrm{H}), 1.19(\mathrm{~d}, J=6.9 \mathrm{~Hz}, 6 \mathrm{H}), 1.10(\mathrm{t}$, $J=6.6 \mathrm{~Hz}, 3 \mathrm{H}), 1.06(\mathrm{t}, J=6.6 \mathrm{~Hz}, 3 \mathrm{H}), 0.87(\mathrm{~d}, J=6.9 \mathrm{~Hz}, 6 \mathrm{H})$.

\section{DFT Calculations}

The Gaussian-16 software package was used for all calculations ${ }^{8}$. All calculations were performed at the $\omega \mathrm{B} 97 \mathrm{xD}$ level of theory using a mixed basis set, consisting of SDD for Ag and 6-311+G(d,p) for all other atoms, and solvation by toluene using the CPCM model. Frequency calculations were performed on optimized structures. Enthalpies and free energies were calculated using the harmonic approximation and adjusted to standard state (1 M concentration). 


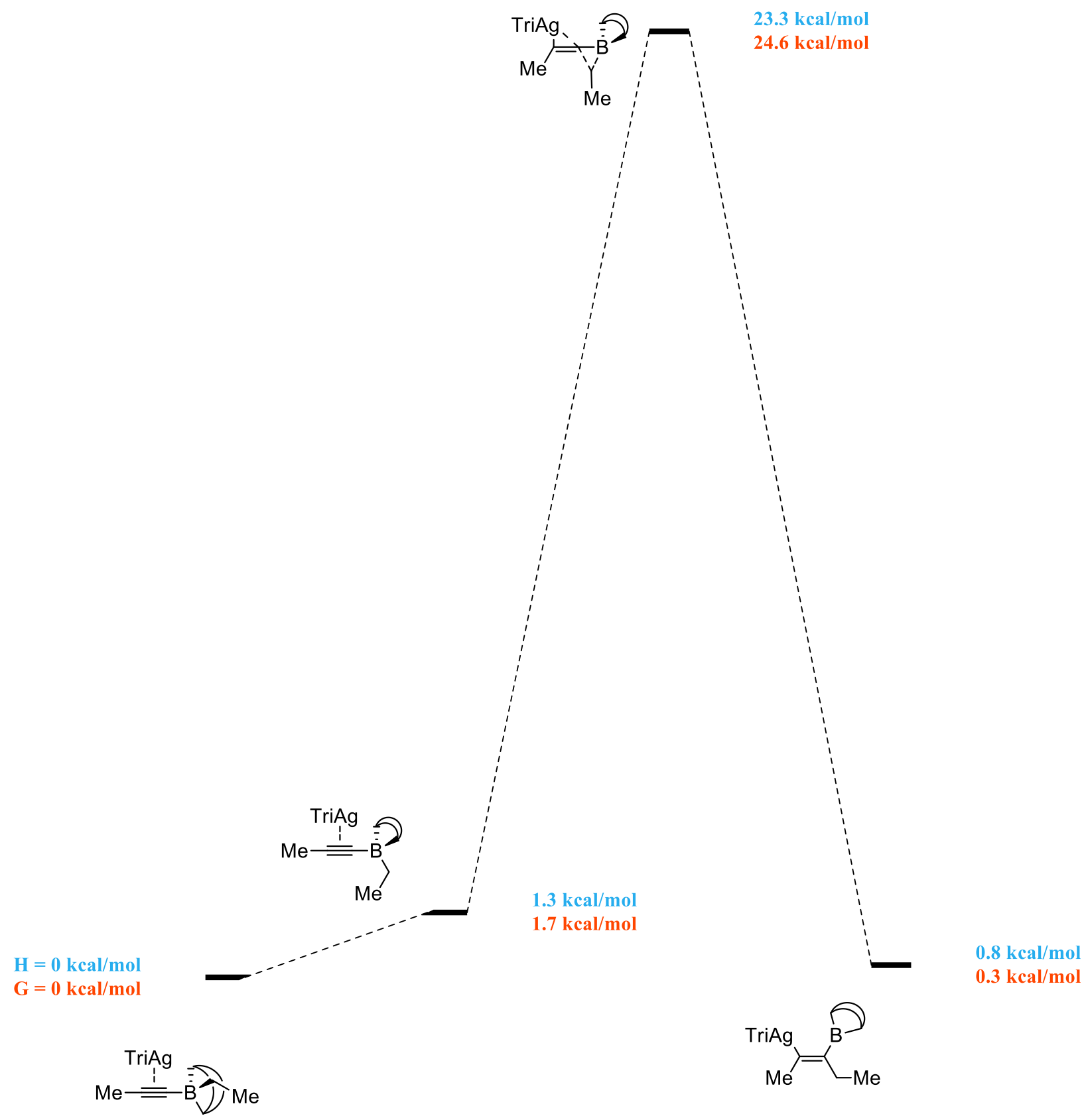

Figure S1. Calculated free energy diagram for the 1,2-metallate shift of a simplified boronate complex. Ethalpies are in blue, free energies are in orange. 


\subsection{TriAg Boronate Complex 19}
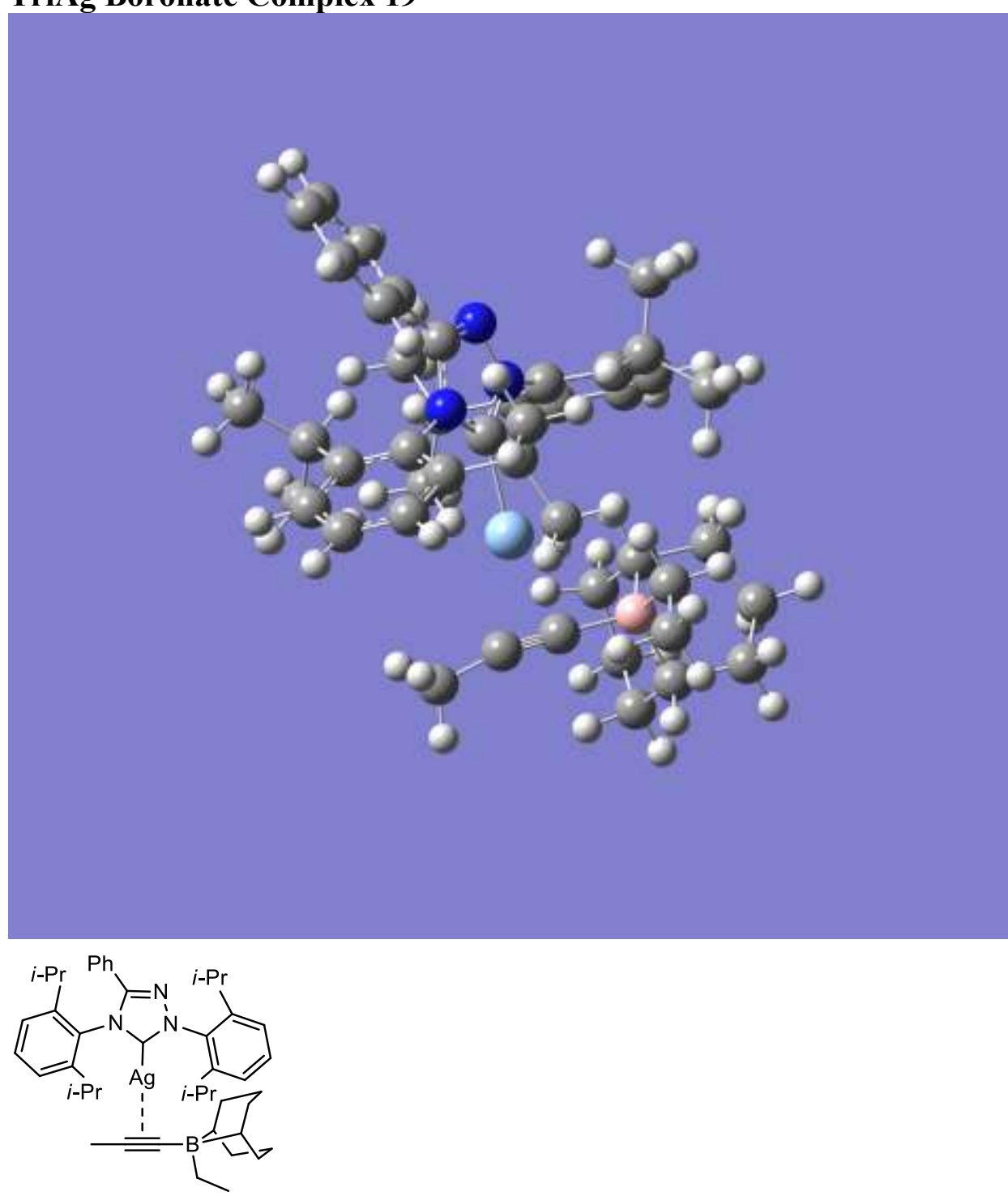

\section{$\mathrm{C}_{45} \mathrm{H}_{61} \mathrm{BN}_{3} \mathrm{Ag}$}

Dihedral angle between Ag, C-B carbon of alkyne, B and B-C carbon of ethyl group $=62.893292^{\circ}$

C
C
C
C
C
C
C
C
C
C
C
C
C
C

$\begin{array}{rrr}5.51113100 & -0.03999500 & -1.97652700 \\ 1.82482000 & 3.62529900 & -1.19986400 \\ 2.54147300 & 3.97330000 & -0.06618800 \\ -0.67017400 & 3.70594000 & -3.05027700 \\ 4.20136500 & 0.64776900 & -1.55366100 \\ 6.17660000 & 0.54888200 & 1.01815700 \\ 0.75710300 & 1.63011300 & -3.31338300 \\ 5.68909700 & -1.47262500 & -1.43855800 \\ 4.76822700 & 1.16271000 & 0.89741000 \\ -0.10085300 & 2.46384000 & -2.35580000 \\ 0.67465600 & 2.84447500 & -1.10613700 \\ 2.13401600 & 3.54079600 & 1.18764200 \\ 6.22223600 & -0.99070300 & 1.03582800 \\ 3.81273500 & 0.45071200 & -0.07838300\end{array}$

C

C

C

C

C

C

$\mathrm{C}$

$\mathrm{C}$

$\mathrm{C}$

C

C

C

C

$\mathrm{C}$

$\begin{array}{rrr}5.28315700 & -1.68600200 & 0.03282200 \\ 0.29119900 & 2.43321700 & 0.17215400 \\ 1.00084600 & 2.74717500 & 1.33502000 \\ 2.76343200 & -1.92337300 & -0.73915400 \\ -2.28638200 & -0.90986600 & -3.40082200 \\ 2.04144200 & -2.54730100 & -1.51759000 \\ 0.54531600 & 2.25905200 & 2.69816800 \\ -0.29156500 & 3.34012400 & 3.39521600 \\ 1.70659800 & 1.79553900 & 3.58039900 \\ 3.18097400 & -1.44217000 & 1.81074700 \\ 1.42341100 & -3.43264800 & -2.51436100 \\ -0.86634500 & 0.27510500 & 0.10197800 \\ -3.31556500 & -0.61577300 & -2.30215700 \\ 3.13419300 & -2.91632700 & 2.22001300\end{array}$




$\begin{array}{lrrr}\mathrm{C} & -4.73592500 & -0.47940400 & -2.85748100 \\ \mathrm{C} & -2.89558200 & 1.08520200 & 0.51845800 \\ \mathrm{C} & -4.99809900 & 2.27408100 & 0.06151000 \\ \mathrm{C} & -3.22973600 & -1.66439500 & -1.20657600 \\ \mathrm{C} & -4.35812000 & 1.16449300 & 0.61826500 \\ \mathrm{C} & -6.38147500 & 2.37136300 & 0.10249100 \\ \mathrm{C} & -2.66095800 & -1.39032300 & 0.04042200 \\ \mathrm{C} & -3.67704700 & -2.96410000 & -1.42981800 \\ \mathrm{C} & -5.11536800 & 0.15750200 & 1.21757000 \\ \mathrm{C} & -2.50720300 & -2.34760600 & 1.04782000 \\ \mathrm{C} & -7.13446400 & 1.36316800 & 0.69559300 \\ \mathrm{C} & -0.52860500 & -2.78823500 & 2.53778400 \\ \mathrm{C} & -1.85543800 & -2.03462000 & 2.38454000 \\ \mathrm{C} & -3.54909400 & -3.93818200 & -0.44981200 \\ \mathrm{C} & -6.49946300 & 0.25998300 & 1.25486200 \\ \mathrm{C} & -2.96730600 & -3.63394200 & 0.77217900 \\ \mathrm{C} & -2.79436400 & -2.33444300 & 3.55899700 \\ \mathrm{H} & 6.35803500 & 0.57362000 & -1.65954200 \\ \mathrm{H} & 2.16877200 & 3.95669700 & -2.17330400 \\ \mathrm{H} & 3.43926100 & 4.57349600 & -0.16080900 \\ \mathrm{H} & 5.56572200 & -0.06275500 & -3.07233400 \\ \mathrm{H} & 0.12983400 & 4.36184400 & -3.40586700 \\ \mathrm{H} & 6.79852500 & 0.91345300 & 0.19692300 \\ \mathrm{H} & 1.61961700 & 2.19809600 & -3.67338600 \\ \mathrm{H} & 4.26951500 & 1.71923700 & -1.79678400 \\ \mathrm{H} & 4.87335500 & 2.22245200 & 0.62121100 \\ \mathrm{H} & -1.27248300 & 3.41306700 & -3.91493100 \\ \mathrm{H} & 6.65280500 & 0.92999700 & 1.93021600 \\ \mathrm{H} & 6.73437100 & -1.77600900 & -1.60136800 \\ \mathrm{H} & 0.16584200 & 1.32572800 & -4.18158400 \\ \mathrm{H} & -1.30219400 & 4.28131400 & -2.36904700 \\ \mathrm{H} & 3.38577500 & 0.25008600 & -2.17133000 \\ \mathrm{H} & 7.26370500 & -1.30627000 & 0.87258900 \\ \mathrm{H} & 1.13618900 & 0.72921800 & -2.82295200 \\ \mathrm{H} & 2.72311300 & 3.80383100 & 2.05764500 \\ \mathrm{H} & 5.07903600 & -2.14836000 & -2.05183400 \\ \mathrm{H} & 4.30004400 & 1.16327900 & 1.88861500 \\ \mathrm{H} & 2.82992600 & 0.93169600 & 0.05231700 \\ \mathrm{H} & -0.95021200 & 1.84277400 & -2.06127900 \\ \mathrm{H} & 5.95803500 & -1.33967000 & 2.04182600 \\ \mathrm{H} & 5.36354400 & -2.76650100 & 0.22456600 \\ \mathrm{H} & -2.31360600 & -0.12894000 & -4.16586500\end{array}$

Energy $=-2087.5806$

Enthalpy $=-2086.5558$

Free Energy $(1 \mathrm{M})=-2086.6959$

Number of imaginary frequencies $=0$

$\begin{array}{rrr}0.31269600 & 4.23513700 & 3.57354800 \\ 2.35202100 & 2.62830800 & 3.87375900 \\ -1.27408100 & -0.94595100 & -2.98643400 \\ 3.78823400 & -0.89904300 & 2.54662300 \\ 2.31847300 & 1.04943000 & 3.06935500 \\ -1.15311100 & 3.62443800 & 2.78627400 \\ -2.49008900 & -1.86946900 & -3.88519600 \\ -4.77449300 & 0.33142200 & -3.58963900 \\ 2.16787300 & -1.01558300 & 1.91765900 \\ -3.05265100 & 0.35480300 & -1.87787400 \\ -0.10046600 & 1.39001700 & 2.54301900 \\ 4.13869900 & -3.35359600 & 2.21146500 \\ 0.59756800 & -4.00327200 & -2.08369300 \\ 2.16821700 & -4.13974200 & -2.88821100 \\ -0.65511600 & 2.97724600 & 4.36085800 \\ 1.31540000 & 1.34776000 & 4.49803800 \\ -4.40571400 & 3.04872600 & -0.41058600 \\ -5.06589900 & -1.39405000 & -3.35792100 \\ 2.52621200 & -3.50069600 & 1.51928800 \\ -5.44490200 & -0.25092600 & -2.05657600 \\ -6.87251000 & 3.23221900 & -0.33577300 \\ -4.12055300 & -3.22149800 & -2.38505800 \\ 0.15906700 & -2.56577000 & 1.71804500 \\ -1.62977100 & -0.96634400 & 2.41426000 \\ -4.63136200 & -0.70512400 & 1.65625000 \\ -0.03494500 & -2.50344100 & 3.47043000 \\ -8.21551500 & 1.43752300 & 0.72203100 \\ -0.69007200 & -3.87018900 & 2.55696000 \\ -3.89965200 & -4.94572800 & -0.64306900 \\ -7.08157800 & -0.52471600 & 1.72341600 \\ -2.86441200 & -4.40974500 & 1.52262900 \\ -3.73276800 & -1.77951900 & 3.47926400 \\ -2.31525000 & -2.05167400 & 4.49983800 \\ -3.03538700 & -3.39963000 & 3.61588400 \\ -0.86562600 & 1.59298400 & 0.28770900 \\ -2.09873600 & 2.11641200 & 0.54246200 \\ -2.16850300 & -0.06032000 & 0.26828100 \\ 3.74974700 & -1.15321000 & 0.29076500 \\ 0.73525900 & -0.94152900 & -0.46429000 \\ 2.71761100 & -3.06983300 & 3.22313900 \\ 1.03645100 & -2.86532500 & -3.36400800 \\ & & \end{array}$




\subsection{TriAg Boronate Complex 19 (rotamer)}
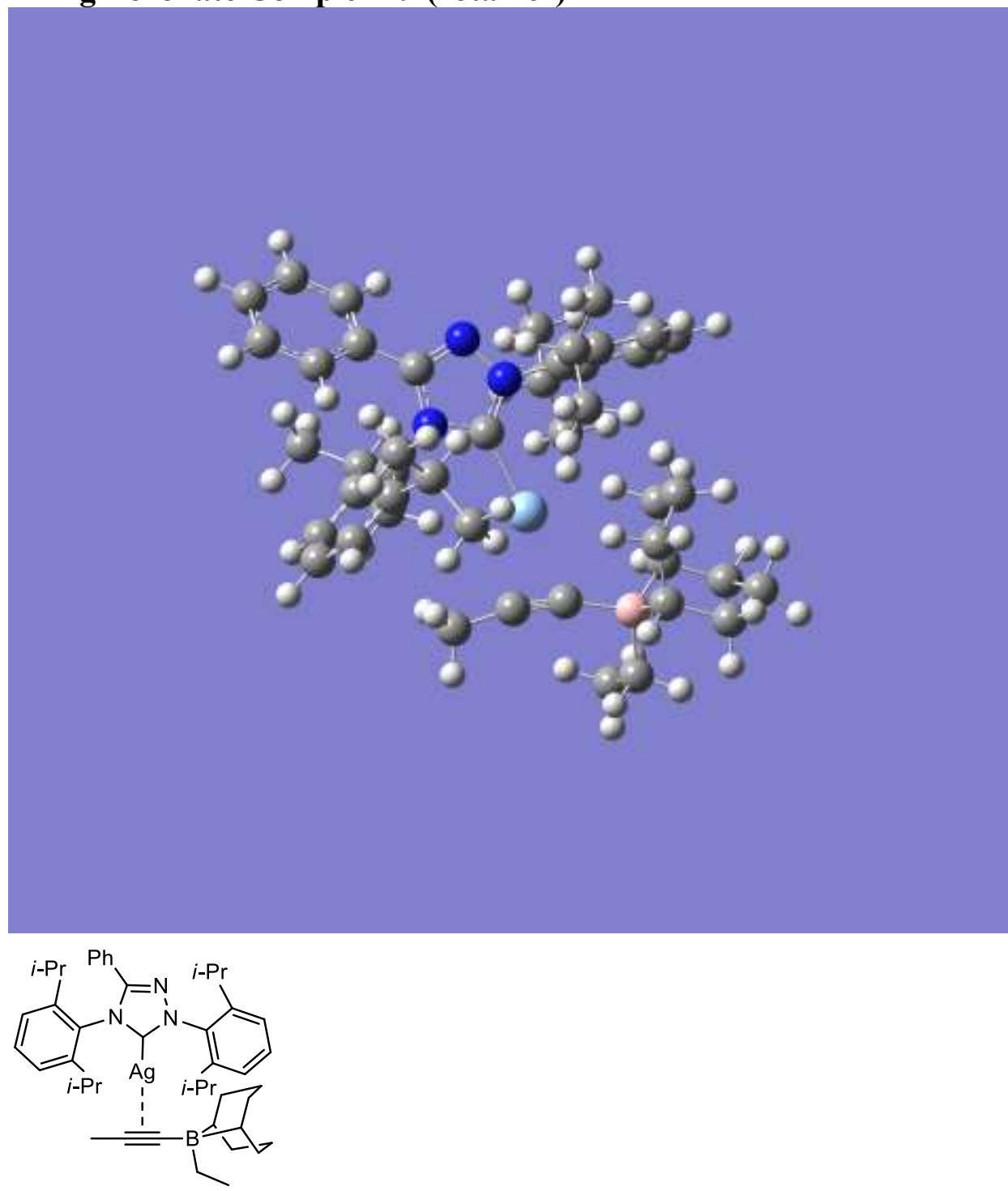

$\mathrm{C}_{45} \mathrm{H}_{61} \mathrm{BN}_{3} \mathrm{Ag}$

Dihedral angle between Ag, C-B carbon of alkyne, B and B-C carbon of ethyl group $=197.08347^{\circ}$

$\begin{array}{lrrr}\mathrm{C} & 3.73619700 & 1.21978800 & 0.99064500 \\ \mathrm{C} & 1.60516300 & 3.91968700 & -1.46362800 \\ \mathrm{C} & 2.06267000 & 4.54470100 & -0.31468900 \\ \mathrm{C} & -0.55825700 & 3.35713700 & -3.62627100 \\ \mathrm{C} & 3.76768700 & -0.04457000 & 1.86221000 \\ \mathrm{C} & 6.57743100 & 0.20413500 & 0.22464400 \\ \mathrm{C} & 1.15421600 & 1.50995400 & -3.36434600 \\ \mathrm{C} & 3.56459300 & 0.94855700 & -0.51192700 \\ \mathrm{C} & 6.14304400 & -0.82489300 & 1.29082100 \\ \mathrm{C} & 0.05576100 & 2.32492000 & -2.67282700 \\ \mathrm{C} & 0.56121700 & 2.99783200 & -1.40857500 \\ \mathrm{C} & 1.48571300 & 4.26958100 & 0.91832500 \\ \mathrm{C} & 5.88120400 & 0.08220600 & -1.14588900 \\ \mathrm{C} & 4.64202700 & -1.18437700 & 1.31018400\end{array}$

$\begin{array}{lrrr}\mathrm{C} & 4.37269200 & -0.22810500 & -1.08496800 \\ \mathrm{C} & 0.01050700 & 2.74212400 & -0.15248200 \\ \mathrm{C} & 0.44133600 & 3.35679200 & 1.02803100 \\ \mathrm{C} & 2.64816800 & -2.17324700 & -0.19373600 \\ \mathrm{C} & -1.73832900 & -2.05050900 & -3.05530200 \\ \mathrm{C} & 1.64481600 & -2.89076800 & -0.19724600 \\ \mathrm{C} & -0.17270000 & 3.00042100 & 2.37262400 \\ \mathrm{C} & -0.33255300 & 4.21350100 & 3.29237300 \\ \mathrm{C} & 0.63568000 & 1.89371900 & 3.06426600 \\ \mathrm{C} & 5.01765400 & -2.89047300 & -0.81223100 \\ \mathrm{C} & 0.62852300 & -3.95171800 & -0.22276700 \\ \mathrm{C} & -0.84900100 & 0.45778000 & 0.09609800 \\ \mathrm{C} & -2.86901600 & -1.49851300 & -2.17808000 \\ \mathrm{C} & 4.71466200 & -3.24071000 & -2.27243000\end{array}$




$\begin{array}{lrrr}\mathrm{C} & -4.24346700 & -1.66306200 & -2.83353200 \\ \mathrm{C} & -3.00320700 & 1.02030500 & 0.04269300 \\ \mathrm{C} & -5.12762100 & 1.71930900 & -0.97457500 \\ \mathrm{C} & -2.81683200 & -2.13357600 & -0.80031400 \\ \mathrm{C} & -4.46303800 & 0.89673000 & -0.06222600 \\ \mathrm{C} & -6.50146300 & 1.61144600 & -1.13583100 \\ \mathrm{C} & -2.41624300 & -1.42097600 & 0.33234200 \\ \mathrm{C} & -3.12956700 & -3.48011500 & -0.62910400 \\ \mathrm{C} & -5.18780000 & -0.02939600 & 0.68905400 \\ \mathrm{C} & -2.28279100 & -1.99869400 & 1.59972300 \\ \mathrm{C} & -7.22049600 & 0.68280900 & -0.39052900 \\ \mathrm{C} & -0.48392800 & -1.81576800 & 3.34763200 \\ \mathrm{C} & -1.79362400 & -1.22409000 & 2.81268300 \\ \mathrm{C} & -3.03647600 & -4.07916200 & 0.61820200 \\ \mathrm{C} & -6.56238400 & -0.13265300 & 0.52317000 \\ \mathrm{C} & -2.60925700 & -3.34819900 & 1.71719500 \\ \mathrm{C} & -2.86080300 & -1.16101800 & 3.91132000 \\ \mathrm{H} & 4.65237300 & 1.79159500 & 1.15442300 \\ \mathrm{H} & 2.07054100 & 4.14458900 & -2.41682400 \\ \mathrm{H} & 2.88253300 & 5.25128000 & -0.37741400 \\ \mathrm{H} & 2.92328900 & 1.87327500 & 1.32226400 \\ \mathrm{H} & 0.19450400 & 4.07182100 & -3.97186700 \\ \mathrm{H} & 6.41734100 & 1.21309000 & 0.61286500 \\ \mathrm{H} & 1.98872100 & 2.14598800 & -3.67314300 \\ \mathrm{H} & 4.08353900 & 0.23932100 & 2.87740700 \\ \mathrm{H} & 6.46174900 & -0.45201200 & 2.27607000 \\ \mathrm{H} & -0.97543700 & 2.85871800 & -4.50569900 \\ \mathrm{H} & 7.66169600 & 0.12372500 & 0.07926900 \\ \mathrm{H} & 3.77124900 & 1.87695900 & -1.06375900 \\ \mathrm{H} & 0.75285300 & 1.02576400 & -4.25885900 \\ \mathrm{H} & -1.35807300 & 3.91802400 & -3.13597600 \\ \mathrm{H} & 2.73972400 & -0.42451300 & 1.97302100 \\ \mathrm{H} & 6.06227200 & 1.01241100 & -1.70540300 \\ \mathrm{H} & 1.55414000 & 0.73487100 & -2.70674700 \\ \mathrm{H} & 1.86438200 & 4.76401000 & 1.80483600 \\ \mathrm{H} & 2.49403800 & 0.76134900 & -0.70211300 \\ \mathrm{H} & 6.70517400 & -1.75107100 & 1.12956300 \\ \mathrm{H} & 4.53211100 & -2.03424300 & 2.00140200 \\ \mathrm{H} & -0.73900000 & 1.62788800 & -2.39686300 \\ \mathrm{H} & 6.36768800 & -0.71292400 & -1.72218200 \\ \mathrm{H} & 4.03519200 & -0.36135900 & -2.12450400 \\ \mathrm{H} & -1.74131400 & -1.56101000 & -4.03288200 \\ & & & \end{array}$

\begin{tabular}{lrrr}
$\mathrm{H}$ & 0.63459600 & 4.60238500 & 3.62275900 \\
$\mathrm{H}$ & 1.64597900 & 2.24040400 & 3.30031100 \\
$\mathrm{H}$ & -0.76308600 & -1.87758500 & -2.58983400 \\
$\mathrm{H}$ & 6.09538800 & -2.70301100 & -0.72395800 \\
$\mathrm{H}$ & 0.73070800 & 1.00753900 & 2.43209400 \\
$\mathrm{H}$ & -0.87509400 & 5.02136100 & 2.79534700 \\
$\mathrm{H}$ & -1.85296900 & -3.12689800 & -3.21500700 \\
$\mathrm{H}$ & -4.26696700 & -1.13547900 & -3.79065200 \\
$\mathrm{H}$ & 4.82768500 & -3.77527700 & -0.18569000 \\
$\mathrm{H}$ & -2.69328100 & -0.42616400 & -2.07422600 \\
$\mathrm{H}$ & -1.17734800 & 2.61136600 & 2.18686100 \\
$\mathrm{H}$ & 4.97152000 & -2.40742500 & -2.93656100 \\
$\mathrm{H}$ & 1.11897200 & -4.92623000 & -0.29228600 \\
$\mathrm{H}$ & -0.04229300 & -3.84291700 & -1.07828400 \\
$\mathrm{H}$ & -0.89016100 & 3.92667000 & 4.18777100 \\
$\mathrm{H}$ & 0.14907100 & 1.59680800 & 3.99810200 \\
$\mathrm{H}$ & -4.55913300 & 2.43071900 & -1.56155100 \\
$\mathrm{H}$ & -4.47429000 & -2.71419800 & -3.02839700 \\
$\mathrm{H}$ & 3.64779800 & -3.44721400 & -2.41632400 \\
$\mathrm{H}$ & -5.03131300 & -1.25142300 & -2.19628300 \\
$\mathrm{H}$ & -7.00993300 & 2.24831200 & -1.85005200 \\
$\mathrm{H}$ & -3.44122400 & -4.06970200 & -1.48392700 \\
$\mathrm{H}$ & 0.28170300 & -1.86204800 & 2.56826000 \\
$\mathrm{H}$ & -1.58209700 & -0.19737100 & 2.50769600 \\
$\mathrm{H}$ & -4.68752900 & -0.67145200 & 1.40187800 \\
$\mathrm{H}$ & -0.09843900 & -1.19966300 & 4.16405700 \\
$\mathrm{H}$ & -8.29286200 & 0.59502300 & -0.52162800 \\
$\mathrm{H}$ & -0.63426800 & -2.82888700 & 3.73204700 \\
$\mathrm{H}$ & -3.28488800 & -5.12819700 & 0.73254100 \\
$\mathrm{H}$ & -7.11905600 & -0.85328700 & 1.11048400 \\
$\mathrm{H}$ & -2.52270600 & -3.83553700 & 2.68202500 \\
$\mathrm{H}$ & -3.77999400 & -0.69089300 & 3.55214800 \\
$\mathrm{H}$ & -2.49203800 & -0.57511700 & 4.75741900 \\
$\mathrm{H}$ & -3.11239900 & -2.15952900 & 4.28018300 \\
$\mathrm{~N}$ & -1.03605300 & 1.76673300 & -0.05348300 \\
$\mathrm{~N}$ & -2.34893800 & 2.13869000 & -0.09632700 \\
$\mathrm{~N}$ & -2.11375900 & -0.02501800 & 0.18086400 \\
$\mathrm{~B}$ & 4.17399500 & -1.60514700 & -0.20952700 \\
$\mathrm{Ag}$ & 0.87154800 & -0.74139300 & -0.02075900 \\
$\mathrm{H}$ & 5.26976300 & -4.11908900 & -2.62364600 \\
$\mathrm{H}$ & 0.01476800 & -3.93821900 & 0.68100400 \\
& & & \\
\hline
\end{tabular}

Energy $=-2087.5782$

Enthalpy $=-2086.5538$

Free Energy $(1 \mathrm{M})=-2086.6932$

Number of imaginary frequencies $=0$ 


\subsection{1,2-Metallate Shift Transition State}

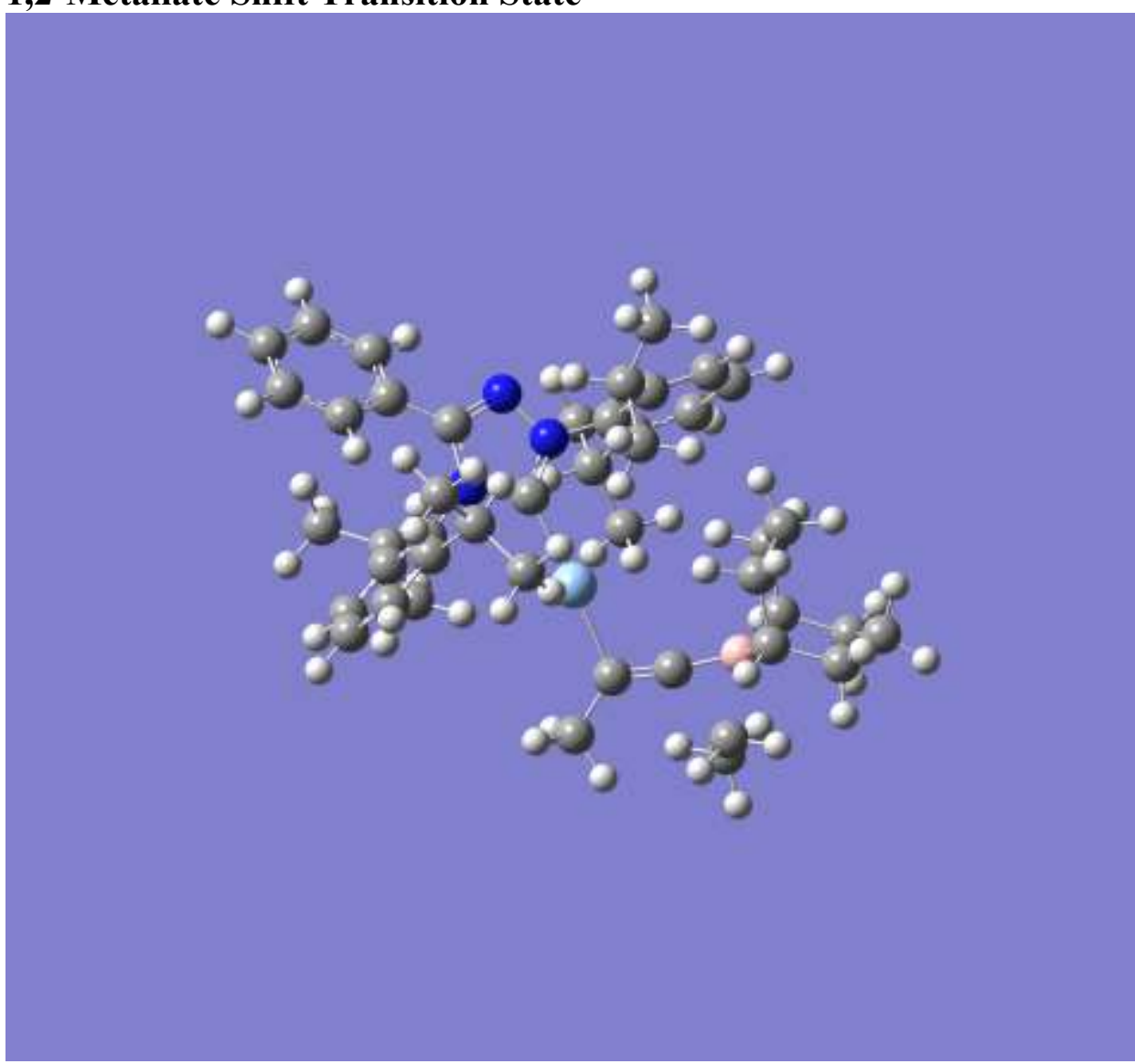

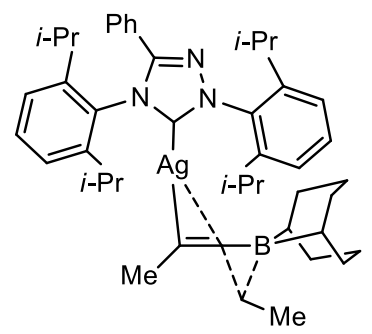

\section{$\mathrm{C}_{45} \mathrm{H}_{61} \mathrm{BN}_{3} \mathrm{Ag}$}

$\begin{array}{lrrr}\mathrm{C} & 1.74425400 & 1.28354800 & 1.01483900 \\ \mathrm{C} & -0.29014600 & 1.93794700 & -2.76617000 \\ \mathrm{C} & -0.64860300 & 2.72315400 & -1.68486500 \\ \mathrm{C} & -0.84982100 & 0.31443000 & -5.35838000 \\ \mathrm{C} & 1.99432900 & 0.04789600 & 1.89531500 \\ \mathrm{C} & 4.79368300 & 1.68624300 & 1.56080300 \\ \mathrm{C} & 1.23596500 & -0.38400100 & -4.09418400 \\ \mathrm{C} & 2.29935900 & 1.16958800 & -0.41591600 \\ \mathrm{C} & 4.51465600 & 0.41253700 & 2.38110700 \\ \mathrm{C} & -0.29022500 & -0.24011700 & -4.04377000 \\ \mathrm{C} & -0.71636700 & 0.61403700 & -2.86374300 \\ \mathrm{C} & -1.43270700 & 2.20228400 & -0.66405900 \\ \mathrm{C} & 4.83764700 & 1.47683000 & 0.03663600 \\ \mathrm{C} & 3.42746600 & -0.52160900 & 1.81615100 \\ \mathrm{C} & 3.72343300 & 0.58196700 & -0.53493100\end{array}$

$\begin{array}{lrrr}\mathrm{C} & -1.51982900 & 0.13041600 & -1.83180000 \\ \mathrm{C} & -1.88451700 & 0.88854000 & -0.71251800 \\ \mathrm{C} & 3.22219500 & -2.06284800 & -0.37569200 \\ \mathrm{C} & -0.14540600 & -4.96280900 & -4.51854500 \\ \mathrm{C} & 2.70667400 & -3.12024800 & -0.92476600 \\ \mathrm{C} & -2.68579100 & 0.27140600 & 0.42273300 \\ \mathrm{C} & -3.59098400 & 1.27442000 & 1.13993300 \\ \mathrm{C} & -1.74644400 & -0.42208700 & 1.42090100 \\ \mathrm{C} & 5.12099200 & -1.92862700 & -0.10455400 \\ \mathrm{C} & 3.38260800 & -4.38291300 & -1.38183800 \\ \mathrm{C} & -1.36492800 & -2.31999000 & -1.55625200 \\ \mathrm{C} & -1.60265500 & -4.92888800 & -4.04159600 \\ \mathrm{C} & 5.78330800 & -1.84928600 & -1.47133100 \\ \mathrm{C} & -2.54682500 & -5.64670700 & -5.01132900 \\ \mathrm{C} & -3.43937300 & -2.72550300 & -2.27131700\end{array}$




\begin{tabular}{|c|c|c|c|c|c|c|c|}
\hline $\mathrm{C}$ & -5.29707900 & -2.95272100 & -3.86335300 & $\mathrm{H}$ & -1.09479200 & 0.30684900 & 1.91065200 \\
\hline $\mathrm{C}$ & -1.70912000 & -5.48779700 & -2.63428500 & $\mathrm{H}$ & 0.50392800 & -4.41622600 & -3.82823800 \\
\hline $\mathrm{C}$ & -4.62461900 & -3.45222700 & -2.74587500 & $\mathrm{H}$ & 5.65376400 & -1.29284800 & 0.61072900 \\
\hline $\mathrm{C}$ & -6.40173500 & -3.62232300 & -4.36824600 & $\mathrm{H}$ & -1.10424200 & -1.15744700 & 0.93044100 \\
\hline $\mathrm{C}$ & -2.02134200 & -4.68417500 & -1.53595400 & $\mathrm{H}$ & -4.22951400 & 1.81282900 & 0.43536500 \\
\hline $\mathrm{C}$ & -1.45449000 & -6.83412500 & -2.38638000 & $\mathrm{H}$ & 0.22434100 & -5.99019000 & -4.58705700 \\
\hline $\mathrm{C}$ & -5.07561600 & -4.62382900 & -2.13673500 & $\mathrm{H}$ & -2.49147300 & -5.18543700 & -6.00106000 \\
\hline $\mathrm{C}$ & -2.06444400 & -5.15791900 & -0.22063400 & $\mathrm{H}$ & 5.16764600 & -2.92745700 & 0.33245600 \\
\hline $\mathrm{C}$ & -6.84355600 & -4.79449300 & -3.76423500 & $\mathrm{H}$ & -1.90399700 & -3.87953400 & -4.02103300 \\
\hline $\mathrm{C}$ & -1.14825200 & -4.12834100 & 1.88173700 & $\mathrm{H}$ & -3.33995300 & -0.49072800 & -0.00964800 \\
\hline $\mathrm{C}$ & -2.37022400 & -4.25718200 & 0.96488900 & $\mathrm{H}$ & 5.82321600 & -0.81684400 & -1.82669300 \\
\hline $\mathrm{C}$ & -1.50065700 & -7.34127700 & -1.09675200 & $\mathrm{H}$ & 4.43250900 & -4.44665400 & -1.07445700 \\
\hline $\mathrm{C}$ & -6.18169400 & -5.28967400 & -2.64722700 & $\mathrm{H}$ & 3.34884000 & -4.46030200 & -2.47416400 \\
\hline $\mathrm{C}$ & -1.79621700 & -6.51050700 & -0.02601900 & $\mathrm{H}$ & -4.23394900 & 0.74878400 & 1.85077400 \\
\hline $\mathrm{C}$ & -3.60036100 & -4.73937100 & 1.74200500 & $\mathrm{H}$ & -2.32544700 & -0.93511200 & 2.19517700 \\
\hline $\mathrm{H}$ & 2.15947900 & 2.16794000 & 1.50293900 & $\mathrm{H}$ & -4.94055500 & -2.04340900 & -4.33212300 \\
\hline $\mathrm{H}$ & 0.34260400 & 2.35298200 & -3.54258600 & $\mathrm{H}$ & -2.28134200 & -6.70209000 & -5.12224300 \\
\hline $\mathrm{H}$ & -0.30008400 & 3.74792500 & -1.62417600 & $\mathrm{H}$ & 5.23886400 & -2.43125400 & -2.21796600 \\
\hline $\mathrm{H}$ & 0.66624200 & 1.46532300 & 0.95168000 & $\mathrm{H}$ & -3.58244600 & -5.58990000 & -4.66468100 \\
\hline $\mathrm{H}$ & -0.44895500 & 1.30998300 & -5.57066700 & $\mathrm{H}$ & -6.91482500 & -3.23139700 & -5.23914400 \\
\hline $\mathrm{H}$ & 4.04447700 & 2.44419200 & 1.79845600 & $\mathrm{H}$ & -1.20471800 & -7.49137500 & -3.21186600 \\
\hline $\mathrm{H}$ & 1.72087800 & 0.58190600 & -4.26373500 & $\mathrm{H}$ & -0.27619100 & -3.76351400 & 1.33219300 \\
\hline $\mathrm{H}$ & 1.72726400 & 0.29035000 & 2.93374500 & $\mathrm{H}$ & -2.59758100 & -3.25721900 & 0.58887800 \\
\hline $\mathrm{H}$ & 4.27254700 & 0.70407900 & 3.41237900 & $\mathrm{H}$ & -4.56711600 & -5.02268200 & -1.26890500 \\
\hline $\mathrm{H}$ & -0.57740700 & -0.33882000 & -6.19226900 & $\mathrm{H}$ & -1.35616100 & -3.42660700 & 2.69378400 \\
\hline $\mathrm{H}$ & 5.74908300 & 2.11342100 & 1.88697500 & $\mathrm{H}$ & -7.70320900 & -5.32055800 & -4.16341100 \\
\hline $\mathrm{H}$ & 2.24738300 & 2.15637700 & -0.89599000 & $\mathrm{H}$ & -0.88551800 & -5.09280800 & 2.32655300 \\
\hline $\mathrm{H}$ & 1.52461000 & -1.05160600 & -4.91102900 & $\mathrm{H}$ & -1.29399200 & -8.39127400 & -0.92272700 \\
\hline $\mathrm{H}$ & -1.93955200 & 0.39124900 & -5.32094100 & $\mathrm{H}$ & -6.52524400 & -6.19940000 & -2.16891700 \\
\hline $\mathrm{H}$ & 1.30956200 & -0.75104000 & 1.57917300 & $\mathrm{H}$ & -1.81222200 & -6.91836000 & 0.97858300 \\
\hline $\mathrm{H}$ & 4.83341000 & 2.46057800 & -0.45283100 & $\mathrm{H}$ & -4.48426200 & -4.79834300 & 1.10099400 \\
\hline $\mathrm{H}$ & 1.63127100 & -0.79720600 & -3.16216000 & $\mathrm{H}$ & -3.82258300 & -4.04700700 & 2.55847200 \\
\hline $\mathrm{H}$ & -1.68569900 & 2.82769900 & 0.18321800 & $\mathrm{H}$ & -3.43555200 & -5.72741500 & 2.18116200 \\
\hline $\mathrm{H}$ & 1.62731700 & 0.51863700 & -0.99092000 & $\mathrm{~N}$ & -2.01751100 & -1.21314500 & -1.91375200 \\
\hline $\mathrm{H}$ & 5.44756500 & -0.16315400 & 2.45289200 & $\mathrm{~N}$ & -3.28828300 & -1.43586700 & -2.36373700 \\
\hline $\mathrm{H}$ & 3.44163700 & -1.44553400 & 2.40806800 & $\mathrm{~N}$ & -2.28830900 & -3.29344300 & -1.76741500 \\
\hline $\mathrm{H}$ & -0.70508500 & -1.24207900 & -3.91018600 & B & 3.66412800 & -0.80958700 & 0.25502800 \\
\hline $\mathrm{H}$ & 5.80159700 & 1.01824600 & -0.22447700 & $\mathrm{Ag}$ & 0.66521200 & -2.68757300 & -1.14868900 \\
\hline $\mathrm{H}$ & 3.91742700 & 0.44484000 & -1.60580100 & $\mathrm{H}$ & 6.81097900 & -2.22739400 & -1.43403400 \\
\hline $\mathrm{H}$ & -0.05849900 & -4.50626900 & -5.50849000 & $\mathrm{H}$ & 2.86136400 & -5.26164700 & -0.99209400 \\
\hline $\mathrm{H}$ & -3.01285400 & 2.00739200 & 1.70992100 & & & & \\
\hline
\end{tabular}

Energy $=-2087.5428$

Enthalpy $=-2086.5187$

Free Energy $(1 \mathrm{M})=-2086.6567$

Number of imaginary frequencies $=1$ at $-550 \mathrm{~cm}^{-1}$

Vibrational motion corresponds to the expected reaction coordinate. 


\subsection{Bimetallic Tetrasubstituted Alkene 20}
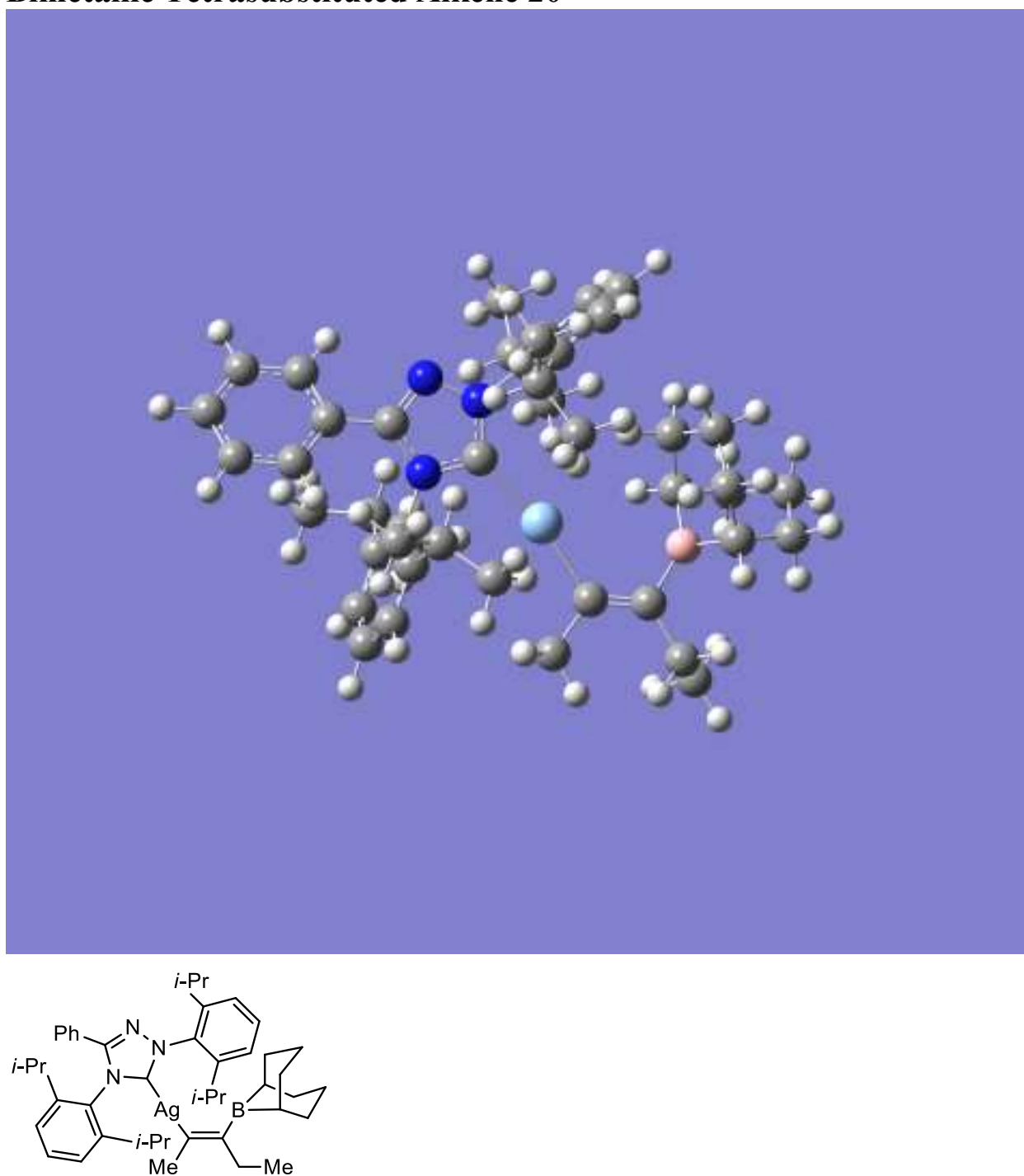

\section{$\mathrm{C}_{45} \mathrm{H}_{61} \mathrm{BN}_{3} \mathrm{Ag}$}

$\begin{array}{rrr}4.42615200 & 1.74853300 & 0.99939100 \\ 1.35776600 & 4.25832500 & -1.11165400 \\ 1.92139200 & 4.65474800 & 0.09198400 \\ -0.52400400 & 3.92802800 & -3.44006800 \\ 4.78038400 & 0.50575800 & 1.82729400 \\ 6.38955600 & 0.40027100 & -1.03224100 \\ 0.74903500 & 1.76858000 & -3.09171700 \\ 3.50804300 & 1.46355300 & -0.19989100 \\ 6.50907500 & -0.54332700 & 0.17768300 \\ -0.20802600 & 2.79124400 & -2.46480500 \\ 0.36072900 & 3.28652200 & -1.14746500 \\ 1.50534400 & 4.08605100 & 1.28649100 \\ 5.09255300 & 0.21888400 & -1.83470700 \\ 5.21079100 & -0.72939300 & 1.00492400 \\ 3.79962400 & 0.16554200 & -0.97494800 \\ -0.03992200 & 2.74150300 & 0.07416300 \\ 0.50819600 & 3.11386800 & 1.30460200\end{array}$

C

C

C

C

C

C

$\mathrm{C}$

C

C

C

C

C

$\mathrm{C}$

C

C

C
C

$\begin{array}{rrr}3.41619700 & -2.47387600 & -0.17011600 \\ -1.96916500 & -1.73068100 & -3.30857100 \\ 2.06202700 & -2.55167700 & -0.27264000 \\ 0.08526300 & 2.44966800 & 2.60345200 \\ -0.12958100 & 3.45602200 & 3.73713400 \\ 1.10308000 & 1.37325900 & 3.00322200 \\ 4.33644200 & -3.68639800 & -0.07584500 \\ 1.34259500 & -3.88980400 & -0.25090700 \\ -0.89063800 & 0.42309000 & 0.04811500 \\ -3.03759700 & -1.26930600 & -2.30978500 \\ 4.76754200 & -4.18122700 & -1.46059900 \\ -4.45148500 & -1.35492900 & -2.89298500 \\ -3.04166900 & 1.00831500 & 0.19397300 \\ -5.20500900 & 1.88501000 & -0.57199000 \\ -2.91288000 & -2.04781400 & -1.01288800 \\ -4.50790600 & 0.91692100 & 0.15512400 \\ -6.58764400 & 1.82296000 & -0.66836200\end{array}$




\begin{tabular}{|c|c|c|c|c|c|c|c|}
\hline $\mathrm{C}$ & -2.46882300 & -1.45376100 & 0.17030600 & $\mathrm{H}$ & -7.12028500 & 2.57443300 & -1.23929300 \\
\hline $\mathrm{C}$ & -3.19984100 & -3.41026100 & -0.97473400 & $\mathrm{H}$ & -3.54123100 & -3.91058100 & -1.87408200 \\
\hline $\mathrm{C}$ & -5.21144000 & -0.11033200 & 0.78573700 & $\mathrm{H}$ & 0.29994700 & -2.12909700 & 2.33769500 \\
\hline $\mathrm{C}$ & -2.28023000 & -2.15970500 & 1.36429900 & $\mathrm{H}$ & -1.54017100 & -0.46106200 & 2.42511300 \\
\hline $\mathrm{C}$ & -7.28529200 & 0.79492400 & -0.04262100 & $\mathrm{H}$ & -4.68745700 & -0.86928200 & 1.35100900 \\
\hline $\mathrm{C}$ & -0.46699000 & -2.16165100 & 3.11632800 & $\mathrm{H}$ & -0.08392400 & -1.63484500 & 3.99441400 \\
\hline $\mathrm{C}$ & -1.76867800 & -1.50710400 & 2.63921500 & $\mathrm{H}$ & -8.36500900 & 0.74354400 & -0.12341900 \\
\hline $\mathrm{C}$ & -3.04029200 & -4.13799400 & 0.19494600 & $\mathrm{H}$ & -0.62530800 & -3.20741800 & 3.39564200 \\
\hline $\mathrm{C}$ & -6.59525600 & -0.16720200 & 0.68573800 & $\mathrm{H}$ & -3.26507700 & -5.19850500 & 0.20517300 \\
\hline $\mathrm{C}$ & -2.58143400 & -3.51961500 & 1.34899600 & $\mathrm{H}$ & -7.13373000 & -0.96789000 & 1.17886600 \\
\hline $\mathrm{C}$ & -2.83297800 & -1.52680900 & 3.74289600 & $\mathrm{H}$ & -2.44973000 & -4.10548900 & 2.25185300 \\
\hline $\mathrm{H}$ & 5.34597900 & 2.23159200 & 0.66236200 & $\mathrm{H}$ & -3.74307700 & -1.00529800 & 3.43541000 \\
\hline $\mathrm{H}$ & 1.70910400 & 4.70161900 & -2.03605800 & $\mathrm{H}$ & -2.45080600 & -1.03364000 & 4.64078900 \\
\hline $\mathrm{H}$ & 2.70260600 & 5.40664800 & 0.09813100 & $\mathrm{H}$ & -3.10408400 & -2.55173800 & 4.01266900 \\
\hline $\mathrm{H}$ & 3.93301100 & 2.48135700 & 1.64840900 & $\mathrm{~N}$ & -1.07028000 & 1.74416700 & 0.07227700 \\
\hline $\mathrm{H}$ & 0.38328900 & 4.43314200 & -3.78312600 & $\mathrm{~N}$ & -2.37951700 & 2.12952700 & 0.15883900 \\
\hline $\mathrm{H}$ & 6.46954800 & 1.43843900 & -0.70497300 & $\mathrm{~N}$ & -2.16145100 & -0.05074200 & 0.14934100 \\
\hline $\mathrm{H}$ & 1.71849100 & 2.22831200 & -3.30794500 & B & 4.05636300 & -1.07138400 & -0.02592800 \\
\hline $\mathrm{H}$ & 5.56311600 & 0.76765300 & 2.55170700 & $\mathrm{Ag}$ & 0.73631500 & -0.92034200 & -0.18443900 \\
\hline $\mathrm{H}$ & 7.32502000 & -0.20143000 & 0.82832400 & $\mathrm{H}$ & 5.45721800 & -5.02883200 & -1.39181300 \\
\hline $\mathrm{H}$ & -1.02771400 & 3.52807500 & -4.32409700 & $\mathrm{H}$ & 0.63379700 & -3.93541000 & 0.58532500 \\
\hline $\mathrm{H}$ & 7.24540800 & 0.23422500 & -1.69599800 & & & & \\
\hline $\mathrm{H}$ & 3.52438800 & 2.32426900 & -0.87989900 & & & & \\
\hline $\mathrm{H}$ & 0.33616700 & 1.38078800 & -4.02734000 & & & & \\
\hline $\mathrm{H}$ & -1.17746000 & 4.67442800 & -2.98147200 & & & & \\
\hline $\mathrm{H}$ & 3.90205900 & 0.21821600 & 2.42127400 & & & & \\
\hline $\mathrm{H}$ & 5.00700600 & 1.02570000 & -2.57415000 & & & & \\
\hline $\mathrm{H}$ & 0.92294600 & 0.92558300 & -2.41786900 & & & & \\
\hline $\mathrm{H}$ & 1.96831900 & 4.39807400 & 2.21537000 & & & & \\
\hline $\mathrm{H}$ & 2.47697300 & 1.39921800 & 0.16754500 & & & & \\
\hline $\mathrm{H}$ & 6.80826000 & -1.53436200 & -0.18872900 & & & & \\
\hline $\mathrm{H}$ & 5.39607600 & -1.54458600 & 1.71476800 & & & & \\
\hline $\mathrm{H}$ & -1.15018600 & 2.27873400 & -2.25538700 & & & & \\
\hline $\mathrm{H}$ & 5.15988100 & -0.71444200 & -2.41048500 & & & & \\
\hline $\mathrm{H}$ & 2.96799000 & -0.01228800 & -1.66583700 & & & & \\
\hline $\mathrm{H}$ & -2.01662000 & -1.12937300 & -4.22067400 & & & & \\
\hline $\mathrm{H}$ & 0.80739200 & 3.93152100 & 4.04029100 & & & & \\
\hline $\mathrm{H}$ & 2.08748900 & 1.81841000 & 3.17777500 & & & & \\
\hline $\mathrm{H}$ & -0.96771400 & -1.62913700 & -2.87979700 & & & & \\
\hline $\mathrm{H}$ & 5.23385800 & -3.41747300 & 0.49251900 & & & & \\
\hline $\mathrm{H}$ & 1.21202300 & 0.61619600 & 2.22170900 & & & & \\
\hline $\mathrm{H}$ & -0.83131400 & 4.24036700 & 3.44302800 & & & & \\
\hline $\mathrm{H}$ & -2.11460000 & -2.77910100 & -3.58548100 & & & & \\
\hline $\mathrm{H}$ & -4.52387300 & -0.73799100 & -3.79270100 & & & & \\
\hline $\mathrm{H}$ & 3.87300300 & -4.51298600 & 0.47248000 & & & & \\
\hline $\mathrm{H}$ & -2.84210300 & -0.21570000 & -2.10192000 & & & & \\
\hline $\mathrm{H}$ & -0.87420100 & 1.95423900 & 2.43450600 & & & & \\
\hline $\mathrm{H}$ & 5.26746900 & -3.38187800 & -2.01772000 & & & & \\
\hline $\mathrm{H}$ & 1.99304700 & -4.77040900 & -0.18991800 & & & & \\
\hline $\mathrm{H}$ & 0.73321400 & -3.99292400 & -1.15650900 & & & & \\
\hline $\mathrm{H}$ & -0.53478500 & 2.94466400 & 4.61435400 & & & & \\
\hline $\mathrm{H}$ & 0.78656300 & 0.87147400 & 3.92217400 & & & & \\
\hline $\mathrm{H}$ & -4.65442300 & 2.67535800 & -1.06782000 & & & & \\
\hline $\mathrm{H}$ & -4.71003200 & -2.38063000 & -3.17144400 & & & & \\
\hline $\mathrm{H}$ & 3.89768000 & -4.49403300 & -2.04585300 & & & & \\
\hline $\mathrm{H}$ & -5.19332200 & -0.99837200 & -2.17262000 & & & & \\
\hline
\end{tabular}


Energy $=-2087.5809$

Enthalpy $=-2086.5545$

Free Energy $(1 \mathrm{M})=-2086.6954$

Number of imaginary frequencies $=0$

\section{X-Ray Crystallography}

All silver complexes were crystalized using the same method. The specified compound was dissolved in a minimal amount of benzene. Pentane was slowly added until the solution became cloudy. A few more drops of benzene were added, and the solution was placed in a $-35{ }^{\circ} \mathrm{C}$ freezer until crystals formed.

\subsection{TriAgEt (5)}

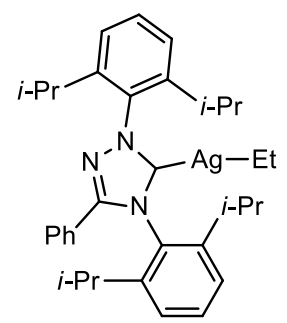

A colorless prism, measuring $0.35 \times 0.25 \times 0.22 \mathrm{~mm}^{3}$ was mounted on a loop with oil. Data was collected at $-173^{\circ} \mathrm{C}$ on a Bruker APEX II single crystal X-ray diffractometer, Mo-radiation.

Crystal-to-detector distance was $40 \mathrm{~mm}$ and exposure time was 10 seconds per frame for all sets. The scan width was $0.5^{\circ}$. Data collection was $99.4 \%$ complete to $25^{\circ}$ in $\vartheta$. A total of 10929 reflections were collected covering the indices, $-17<=\mathrm{h}<=16,-15<=\mathrm{k}<=15,0<=1<=20.5597$ reflections were symmetry independent and the $\mathrm{R}_{\text {int }}=0.008$ indicated that the data was brilliant. Indexing and unit cell refinement indicated a monoclinic lattice. The space group was found to be P 21/c (No. 2).

The data was integrated and scaled using $\mathrm{SAINT}^{9}, \mathrm{SADABS}^{10}$ within the APEX2 ${ }^{11}$ software package by Bruker.

Solution by direct methods (SHELXT ${ }^{12}$ or SIR97 ${ }^{13,14}$ ) produced a complete heavy atom phasing model consistent with the proposed structure. The structure was completed by difference Fourier synthesis with SHELXL ${ }^{15-17}$. Scattering factors are from Waasmair and Kirfel ${ }^{18}$. Hydrogen atoms were placed in geometrically idealized positions and constrained to ride on their parent atoms with $\mathrm{C}---\mathrm{H}$ distances in the range 0.95-1.00 Angstrom. Isotropic thermal parameters $\mathrm{U}_{\text {eq }}$ were fixed such that they were $1.2 \mathrm{U}$ eq of their parent atom Ueq for $\mathrm{CH}^{\prime} \mathrm{s}$ and $1.5 \mathrm{U}$ eq of their parent atom $\mathrm{U}_{\mathrm{eq}}$ in case of methyl groups. All non-hydrogen atoms were refined anisotropically by full-matrix least-squares. 


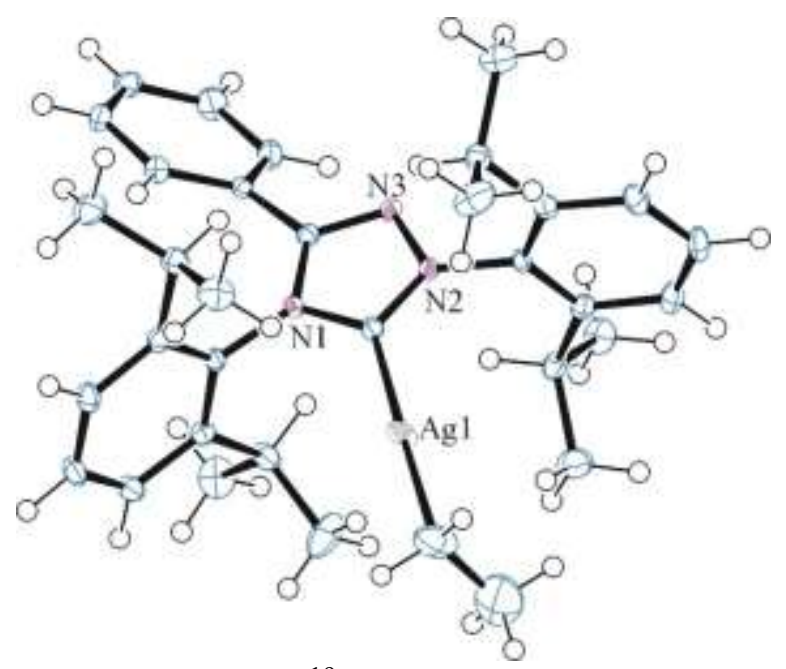

Figure 1. ORTEP $^{19}$ of the structure with thermal ellipsoids at the $50 \%$ probability level.

Table 1: Crystallographic data for the structures provided.

Empirical formula

Formula weight

Temperature

Wavelength

Crystal system

Space group

Unit cell dimensions

Volume

Z

Density (calculated)

Absorption coefficient

$\mathrm{F}(000)$

Crystal size

Theta range for data collection

Index ranges

Reflections collected

Independent reflections

Completeness to theta $=25.000^{\circ}$

Refinement method

Data / restraints / parameters

Goodness-of-fit on $\mathrm{F}^{2}$
C34 H44 Ag N3

602.59

100(2) K

$0.71073 \AA$

Monoclinic

P $21 / \mathrm{c}$

$\mathrm{a}=14.5615(6) \AA$ $\alpha=90^{\circ}$.

$\mathrm{b}=13.0416(6) \AA$ $\beta=110.420(2)^{\circ}$.

$\mathrm{c}=17.2865(7) \AA$ 3076.5(2) $\AA^{3}$

4

$1.301 \mathrm{Mg} / \mathrm{m}^{3}$

$0.681 \mathrm{~mm}^{-1}$

1264

$0.350 \times 0.250 \times 0.220 \mathrm{~mm}^{3}$

1.492 to $25.350^{\circ}$.

$-17<=\mathrm{h}<=16,-15<=\mathrm{k}<=15,0<=\mathrm{l}<=20$

10929

$5597[\mathrm{R}(\mathrm{int})=0.0080]$

$99.4 \%$

Full-matrix least-squares on $\mathrm{F}^{2}$

5597 / 0 / 352

1.055 
Final R indices [I $>2 \operatorname{sigma}(\mathrm{I})]$

$\mathrm{R}$ indices (all data)

Largest diff. peak and hole
$\mathrm{R} 1=0.0319, \mathrm{wR} 2=0.0727$

$\mathrm{R} 1=0.0340, \mathrm{wR} 2=0.0745$

2.075 and -1.851 e. $\AA^{-3}$

\subsection{Crystallization of IPrAg Boronate Complex 14}

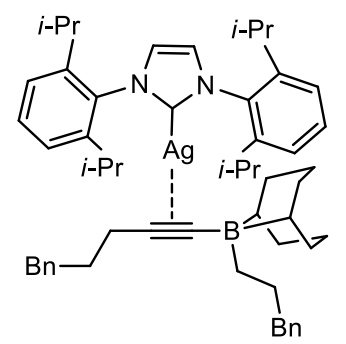

A colorless prism, measuring $0.316 \times 0.179 \times 0.145 \mathrm{~mm}^{3}$ was mounted on a loop with oil. Data was collected at $-173^{\circ} \mathrm{C}$ on a Bruker APEX II single crystal X-ray diffractometer, Mo-radiation.

Crystal-to-detector distance was $40 \mathrm{~mm}$ and exposure time was 10 seconds per frame for all sets. The scan width was $0.5^{\circ}$. Data collection was $100 \%$ complete to $25^{\circ}$ in $\vartheta$. A total of 23746 reflections were collected covering the indices, $-15<=\mathrm{h}<=15,-27<=\mathrm{k}<=27,-27<=1<=27.8761$ reflections were symmetry independent and the $\mathrm{R}_{\text {int }}=0.0221$ indicated that the data was brilliant. Indexing and unit cell refinement indicated a triclinic lattice. The space group was found to be $P$ $21 /$ n (No. 14).

The data was integrated and scaled using SAINT ${ }^{9}$, SADABS ${ }^{10}$ within the APEX2 ${ }^{11}$ software package by Bruker.

Solution by direct methods (SHELXT ${ }^{12}$ or SIR9 $7^{13,14}$ ) produced a complete heavy atom phasing model consistent with the proposed structure. The structure was completed by difference Fourier synthesis with SHELXL ${ }^{15-17}$. Scattering factors are from Waasmair and Kirfel ${ }^{18}$. Hydrogen atoms were placed in geometrically idealized positions and constrained to ride on their parent atoms with C---H distances in the range 0.95-1.00 Angstrom. Isotropic thermal parameters $\mathrm{U}_{\mathrm{eq}}$ were fixed such that they were $1.2 \mathrm{U}_{\mathrm{eq}}$ of their parent atom $\mathrm{Ueq}$ for $\mathrm{CH}$ 's and $1.5 \mathrm{U}_{\mathrm{eq}}$ of their parent atom $\mathrm{U}_{\mathrm{eq}}$ in case of methyl groups. All non-hydrogen atoms were refined anisotropically by full-matrix least-squares. 
The isopropyl moieties show some elevated thermal motion.

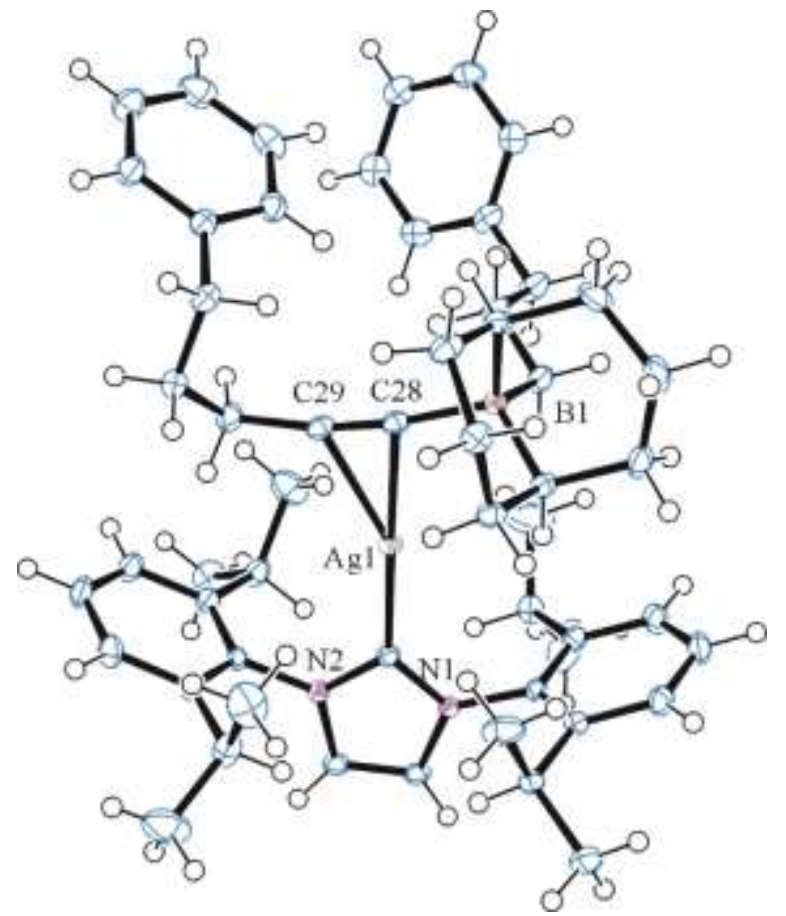

Figure 1. ORTEP ${ }^{19}$ of the structure with thermal ellipsoids at the $50 \%$ probability level.

Table 1: Crystallographic data for the structures provided.

Empirical formula

Formula weight

Temperature

Wavelength

Crystal system

Space group

Unit cell dimensions

Volume

Z

Density (calculated)

Absorption coefficient

$\mathrm{F}(000)$

Crystal size

Theta range for data collection
C55 H72 Ag B N2

879.82

100(2) K

$0.71073 \AA$

Monoclinic

P $21 / \mathrm{n}$

$\mathrm{a}=11.6935(15) \AA \quad \alpha=90^{\circ}$.

$\mathrm{b}=20.883(3) \AA$

$\beta=103.951(5)^{\circ}$.

$\mathrm{c}=20.370(3) \AA$ $\gamma=90^{\circ}$.
$4827.5(12) \AA^{3}$

4

$1.211 \mathrm{Mg} / \mathrm{m}^{3}$

$0.454 \mathrm{~mm}^{-1}$

1872

$0.316 \times 0.179 \times 0.145 \mathrm{~mm}^{3}$

1.418 to $28.368^{\circ}$. 
Index ranges

Reflections collected

Independent reflections

Completeness to theta $=25.000^{\circ}$

Refinement method

Data / restraints / parameters

Goodness-of-fit on $\mathrm{F}^{2}$

Final R indices [I $>2 \operatorname{sigma}(\mathrm{I})]$

$\mathrm{R}$ indices (all data)

Largest diff. peak and hole $-15<=\mathrm{h}<=15,-27<=\mathrm{k}<=27,-27<=\mathrm{l}<=27$

23746

$12052[\mathrm{R}(\mathrm{int})=0.0221]$

$100.0 \%$

Full-matrix least-squares on $\mathrm{F}^{2}$

12052 / 0 / 540

1.043

$\mathrm{R} 1=0.0270, \mathrm{wR} 2=0.0625$

$\mathrm{R} 1=0.0370, \mathrm{wR} 2=0.0681$

0.402 and -0.558 e. $\AA^{-3}$

\subsection{Crystallization of TriAg Alkenyl Complex 24}

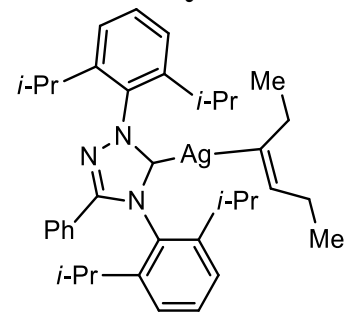

A colorless block, measuring $0.32 \times 0.17 \times 0.15 \mathrm{~mm}^{3}$ was mounted on a loop with oil. Data was collected at $-173^{\circ} \mathrm{C}$ on a Bruker APEX II single crystal X-ray diffractometer, Mo-radiation.

Crystal-to-detector distance was $40 \mathrm{~mm}$ and exposure time was 10 seconds per frame for all sets. The scan width was $0.5^{\circ}$. Data collection was $100 \%$ complete to $25^{\circ}$ in $\vartheta$. A total of 17432 reflections were collected covering the indices, $-16<=\mathrm{h}<=16,-17<=\mathrm{k}<=17,-18<=1<=18 . \quad 8761$ reflections were symmetry independent and the $\mathrm{R}_{\text {int }}=0.0116$ indicated that the data was brilliant. Indexing and unit cell refinement indicated a triclinic lattice. The space group was found to be P $\overline{1}$ (No. 2).

The data was integrated and scaled using $\mathrm{SAINT}^{9}, \mathrm{SADABS}^{10}$ within the APEX2 ${ }^{11}$ software package by Bruker.

Solution by direct methods (SHELXT ${ }^{12}$ or SIR97 ${ }^{13,14}$ ) produced a complete heavy atom phasing model consistent with the proposed structure. The structure was completed by difference Fourier synthesis with SHELXL ${ }^{15-17}$. Scattering factors are from Waasmair and $\mathrm{Kirfel}^{18}$. Hydrogen atoms were placed in geometrically idealized positions and constrained to ride on their parent atoms with C---H distances in the range 0.95-1.00 Angstrom. Isotropic thermal parameters $U_{\text {eq }}$ were fixed such that they were $1.2 \mathrm{U}_{\text {eq }}$ of their parent atom $\mathrm{Ueq}$ for $\mathrm{CH}^{\prime} \mathrm{s}$ and $1.5 \mathrm{U}_{\text {eq }}$ of their parent atom $\mathrm{U}_{\text {eq }}$ in case of methyl groups. All non-hydrogen atoms were refined anisotropically by full-matrix least-squares.

The isopropyl moieties show some elevated thermal motion. 


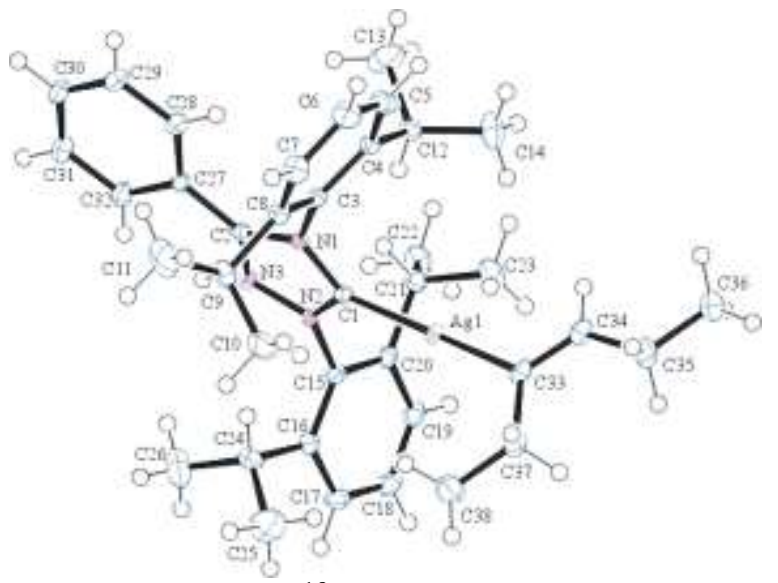

Figure 1. ORTEP ${ }^{19}$ of the structure with thermal ellipsoids at the $50 \%$ probability level.

Table 1: Crystallographic data for the structures provided.

Empirical formula

Formula weight

Temperature

Wavelength

Crystal system

Space group

Unit cell dimensions

Volume

Z

Density (calculated)

Absorption coefficient

$\mathrm{F}(000)$

Crystal size

Theta range for data collection

Index ranges

Reflections collected

Independent reflections

Completeness to theta $=25.000^{\circ}$

Refinement method

Data / restraints / parameters

Goodness-of-fit on $\mathrm{F}^{2}$
C38 H50 Ag N3

656.68

$100(2) \mathrm{K}$

$0.71073 \AA$

Triclinic

$\mathrm{P}-1$

$\mathrm{a}=12.191(5) \AA \quad \alpha=89.336(5)^{\circ}$.

$\mathrm{b}=12.779(5) \AA \quad \beta=71.619(5)^{\circ}$.

$\mathrm{c}=13.479(5) \AA \quad \gamma=62.415(5)^{\circ}$.

$1743.5(12) \AA^{3}$

2

$1.251 \mathrm{Mg} / \mathrm{m}^{3}$

$0.606 \mathrm{~mm}^{-1}$

692

$0.320 \times 0.170 \times 0.150 \mathrm{~mm}^{3}$

1.613 to $28.437^{\circ}$.

$-16<=\mathrm{h}<=16,-17<=\mathrm{k}<=17,-18<=\mathrm{l}<=18$

17432

$8761[\mathrm{R}(\mathrm{int})=0.0116]$

$100.0 \%$

Full-matrix least-squares on $\mathrm{F}^{2}$

$8761 / 0 / 389$

1.080 
Final $\mathrm{R}$ indices $[\mathrm{I}>2 \operatorname{sigma}(\mathrm{I})]$

$\mathrm{R}$ indices (all data)

Largest diff. peak and hole
$\mathrm{R} 1=0.0175, \mathrm{wR} 2=0.0453$

$\mathrm{R} 1=0.0185, \mathrm{wR} 2=0.0460$

0.432 and -0.231 e. $\AA^{-3}$

\section{References}

(1) $\mathrm{Yu}, \mathrm{P}$;; Bismuto, A.; Morandi, B. Iridium-Catalyzed Hydrochlorination and Hydrobromination of Alkynes by Shuttle Catalysis. Angew. Chem. Int. Ed. 2020, 59 (7), 2904-2910.

(2) Lee, M. T.; Goodstein, M. B.; Lalic, G. Synthesis of Isomerically Pure (Z)-Alkenes from Terminal Alkynes and Terminal Alkenes: Silver-Catalyzed Hydroalkylation of Alkynes. $J$. Am. Chem. Soc. 2019, 141 (43), 17086-17091.

(3) Brown, H. C.; Molander, G. A. Vinylic Organoboranes. 2. Improved Procedures for the Protonolysis of Alkenyldialkylboranes Providing a Simplified Stereospecific Synthesis of (Z)-Alkenes. J. Org. Chem. 1986, 51 (24), 4512-4514.

(4) Brown, H. C.; Scouten, C. G.; Liotta, R. Hydroboration. 50. Hydroboration of Representative Alkynes with 9-Borabicyclo[3.3.1]Nonane - a Simple Synthesis of Versatile Vinyl Bora and Gem-Dibora Intermediates. J. Am. Chem. Soc. 1979, 101 (1), 96-99.

(5) Yu, X.-Y.; Patrick, B. O.; James, B. R. New Rhodium(I) Carbene Complexes from Carbene Transfer Reactions. Organometallics 2006, 25 (9), 2359-2363.

(6) Tate, B. K.; Jordan, A. J.; Bacsa, J.; Sadighi, J. P. Stable Mono- and Dinuclear Organosilver Complexes. Organometallics 2017, 36 (5), 964-974.

(7) Tate, B. K.; Wyss, C. M.; Bacsa, J.; Kluge, K.; Gelbaum, L.; Sadighi, J. P. A Dinuclear Silver Hydride and an Umpolung Reaction of CO2. Chem. Sci. 2013, 4 (8), 3068-3074. Gaussian 16, Revision C.01, Frisch, M. J.; Trucks, G. W.; Schlegel, H. B.; Scuseria, G. E.; Robb, M. A.; Cheeseman, J. R.; Scalmani, G.; Barone, V.; Petersson, G. A.; Nakatsuji, H.; Li, X.; Caricato, M.; Marenich, A. V.; Bloino, J.; Janesko, B. G.; Gomperts, R.; Mennucci, B.; Hratchian, H. P.; Ortiz, J. V.; Izmaylov, A. F.; Sonnenberg, J. L.; Williams-Young, D.; Ding, F.; Lipparini, F.; Egidi, F.; Goings, J.; Peng, B.; Petrone, A.; Henderson, T.; Ranasinghe, D.; Zakrzewski, V. G.; Gao, J.; Rega, N.; Zheng, G.; Liang, W.; Hada, M.; Ehara, M.; Toyota, K.; Fukuda, R.; Hasegawa, J.; Ishida, M.; Nakajima, T.; Honda, Y.; Kitao, O.; Nakai, H.; Vreven, T.; Throssell, K.; Montgomery, J. A., Jr.; Peralta, J. E.; Ogliaro, F.; Bearpark, M. J.; Heyd, J. J.; Brothers, E. N.; Kudin, K. N.; Staroverov, V. N.; Keith, T. A.; Kobayashi, R.; Normand, J.; Raghavachari, K.; Rendell, A. P.; Burant, J. C.; Iyengar, S. S.; Tomasi, J.; Cossi, M.; Millam, J. M.; Klene, M.; Adamo, C.; Cammi, R.; Ochterski, J. W.; Martin, R. L.; Morokuma, K.; Farkas, O.; Foresman, J. B.; Fox, D. J. Gaussian, Inc., Wallingford CT, 2016.

(9) Bruker. SAINT; BrukerAXS Inc: Madison, Wisconsin, USA, 2007.

(10) Bruker. SADABS; BrukerAXS Inc: Madison, Wisconsin, USA, 2007.

(11) Bruker. APEX2; BrukerAXS Inc: Madison, Wisconsin, USA, 2007.

(12) Sheldrick, G. M. SHELXT - Integrated Space-Group and Crystal-Structure Determination. Acta Crystallogr. Sect. Found. Adv. 2015, 71 (1), 3-8. 
(13) Altomare, A.; Burla, M. C.; Camalli, M.; Cascarano, G. L.; Giacovazzo, C.; Guagliardi, A.; Moliterni, A. G. G.; Polidori, G.; Spagna, R. SIR97: A New Tool for Crystal Structure Determination and Refinement. J. Appl. Crystallogr. 1999, 32 (1), 115-119.

(14) Altomare, A.; Cascarano, G.; Giacovazzo, C.; Guagliardi, A. Completion and Refinement of Crystal Structures with SIR92. J. Appl. Crystallogr. 1993, 26 (3), 343-350.

(15) G. M. Sheldrick. SHELXL-97, Program for the Refinement of Crystal Structures; University of Göttingen: Germany, 1997.

(16) Sheldrick, G. M. Crystal Structure Refinement with SHELXL. Acta Crystallogr. Sect. C Struct. Chem. 2015, 71 (1), 3-8. https://doi.org/10.1107/S2053229614024218.

(17) S. Mackay; C. Edwards; A. Henderson; C. Gilmore; K. Shankland. MaXus: A Computer Program for the Solution and Refinement of Crystal Structures from Diffraction Data; University of Glasgow: Scotland, 1997.

(18) Waasmaier, D.; Kirfel, A. New Analytical Scattering-Factor Functions for Free Atoms and Ions. Acta Crystallogr. A 1995, 51 (3), 416-431.

(19) Farrugia, L. J. ORTEP-3 for Windows - a Version of ORTEP-III with a Graphical User Interface (GUI). J. Appl. Crystallogr. 1997, 30 (5), 565-565. 
8. Spectra 

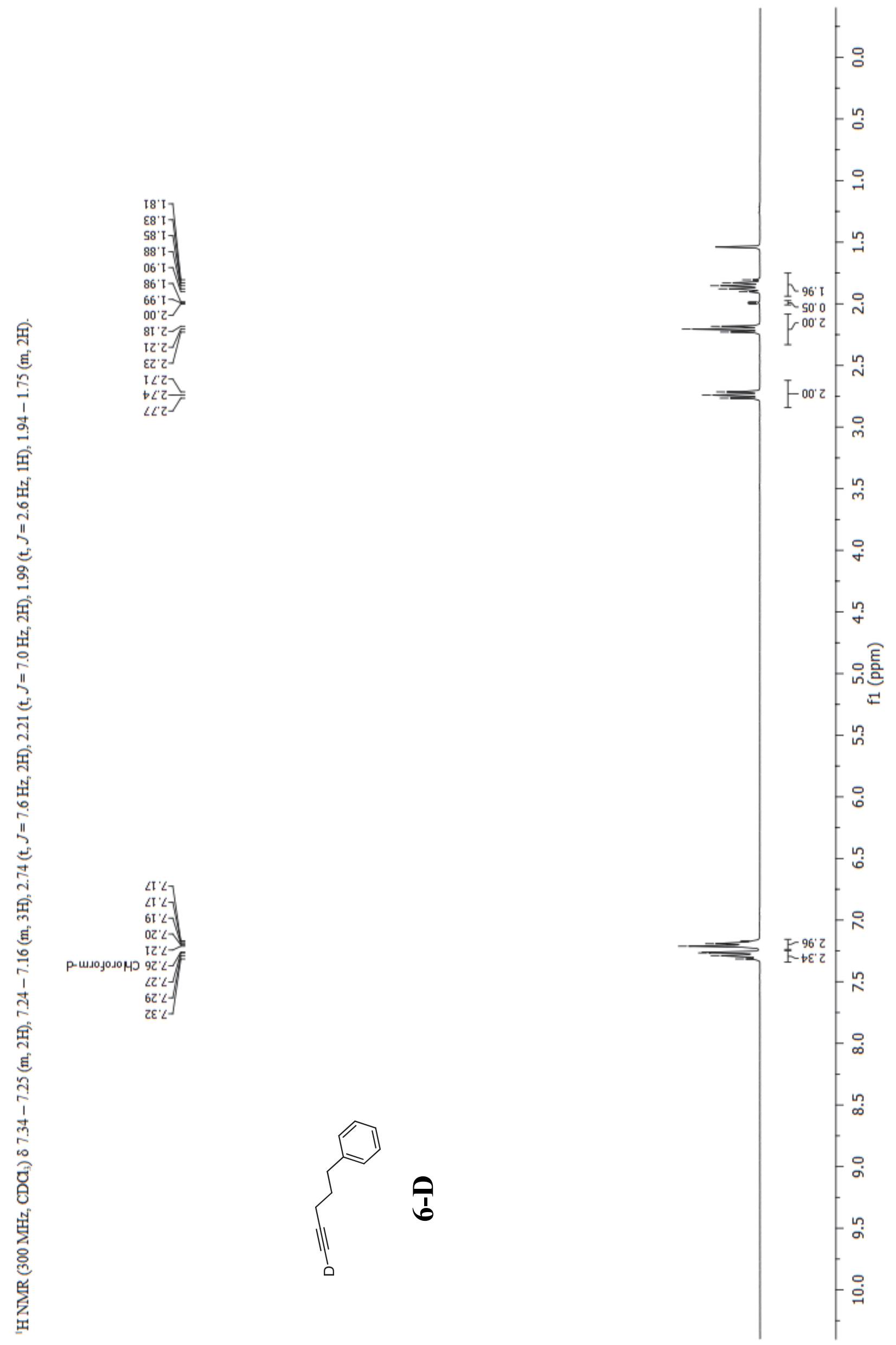


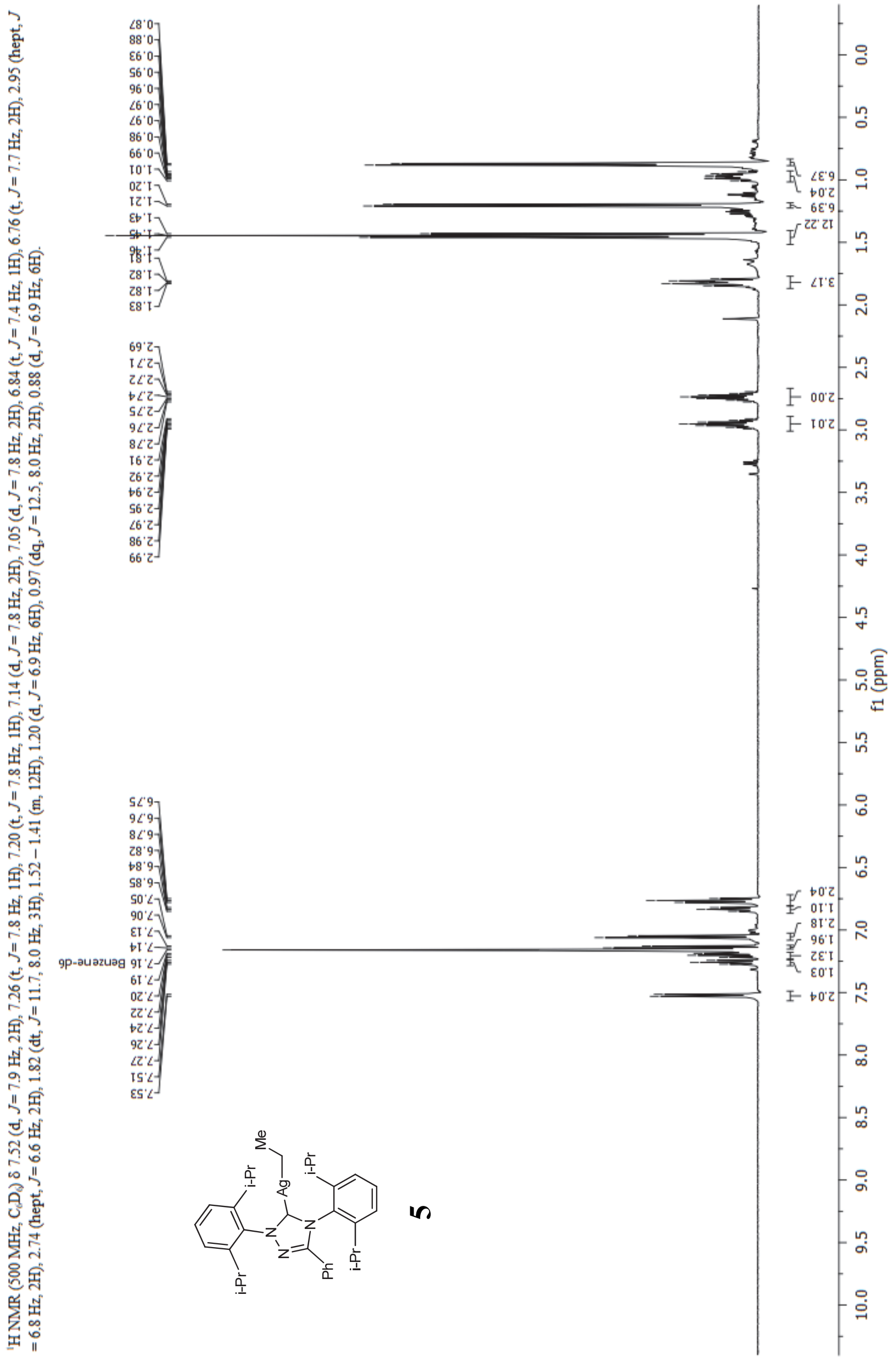



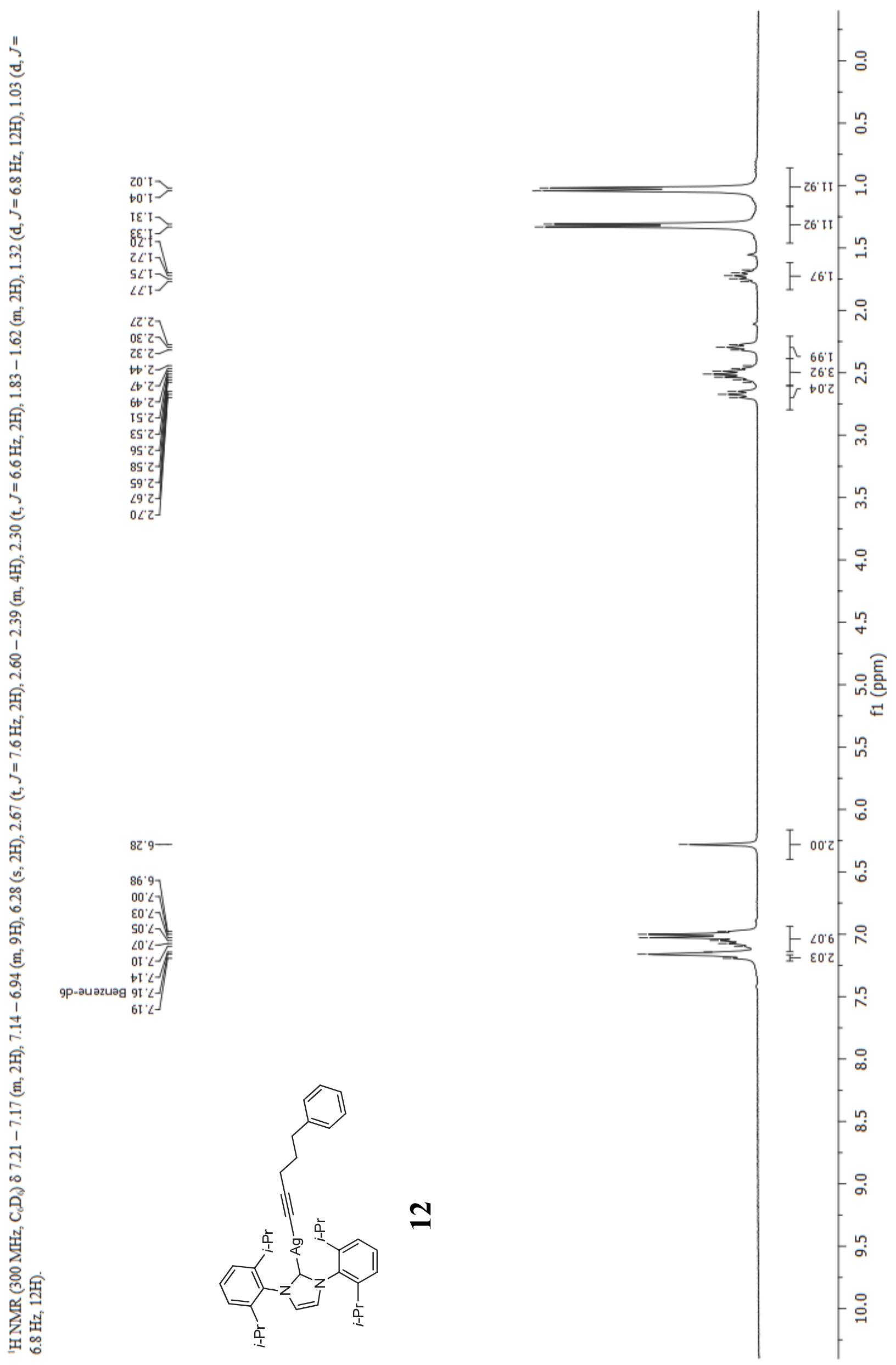


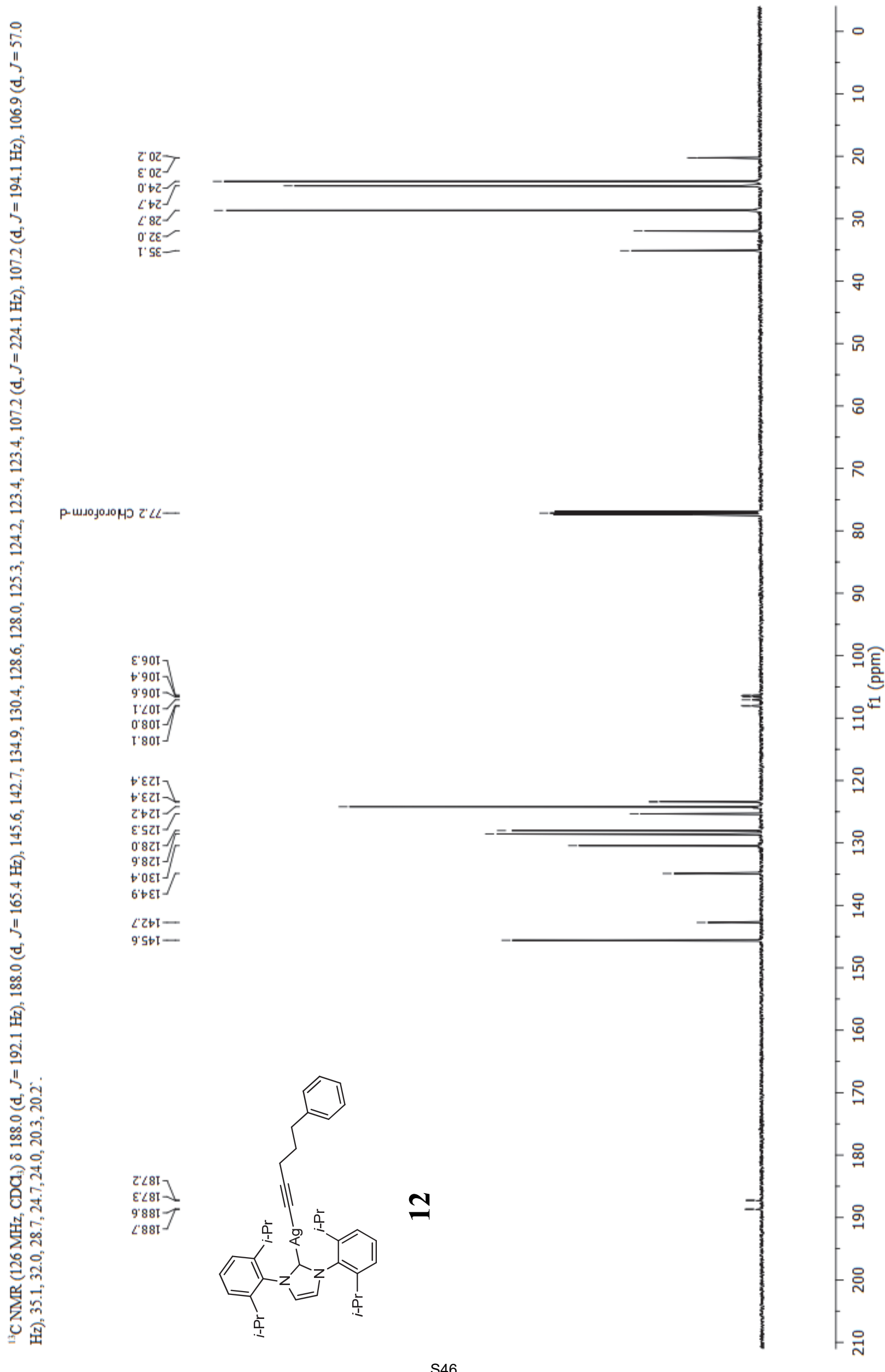



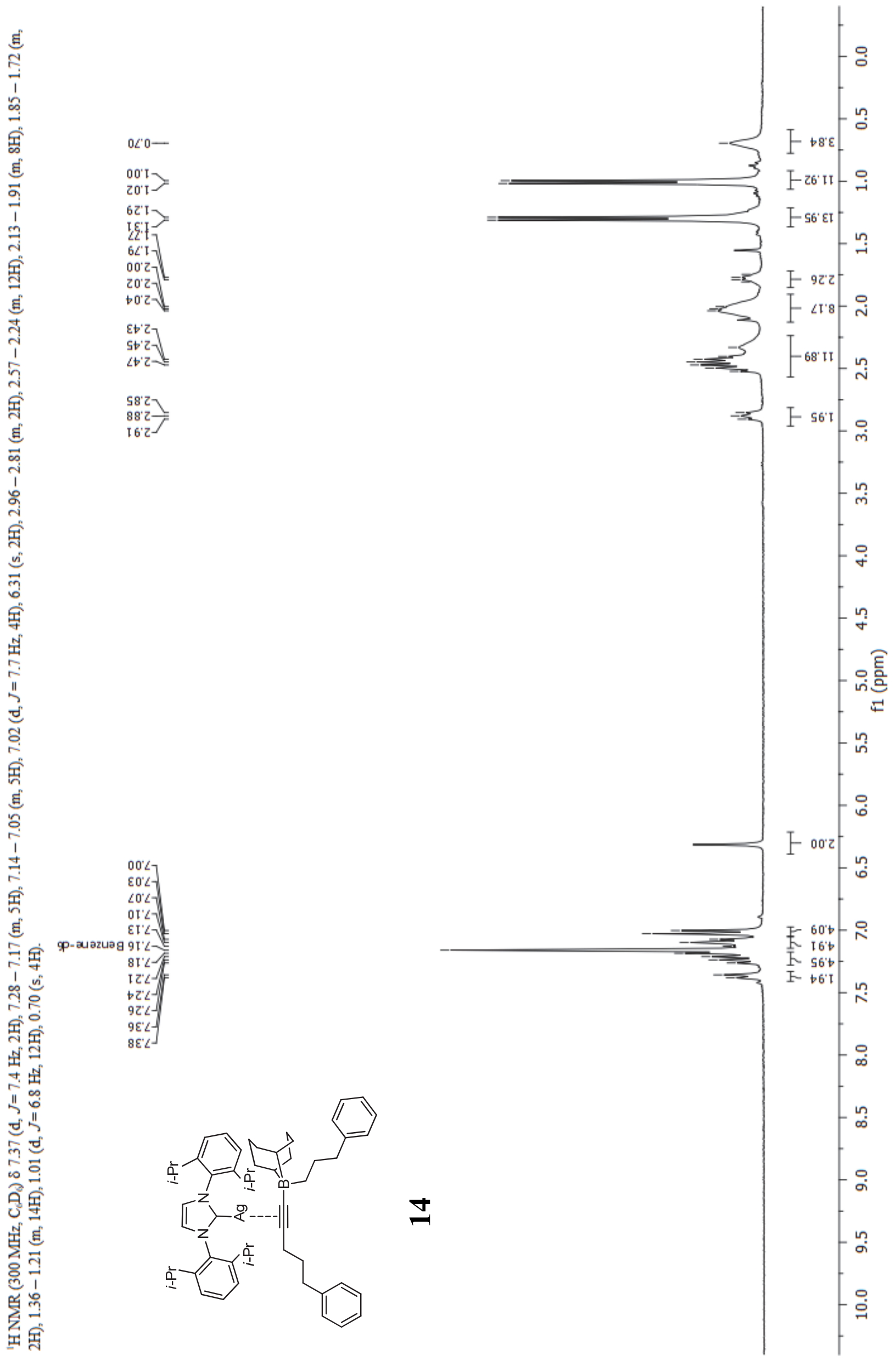


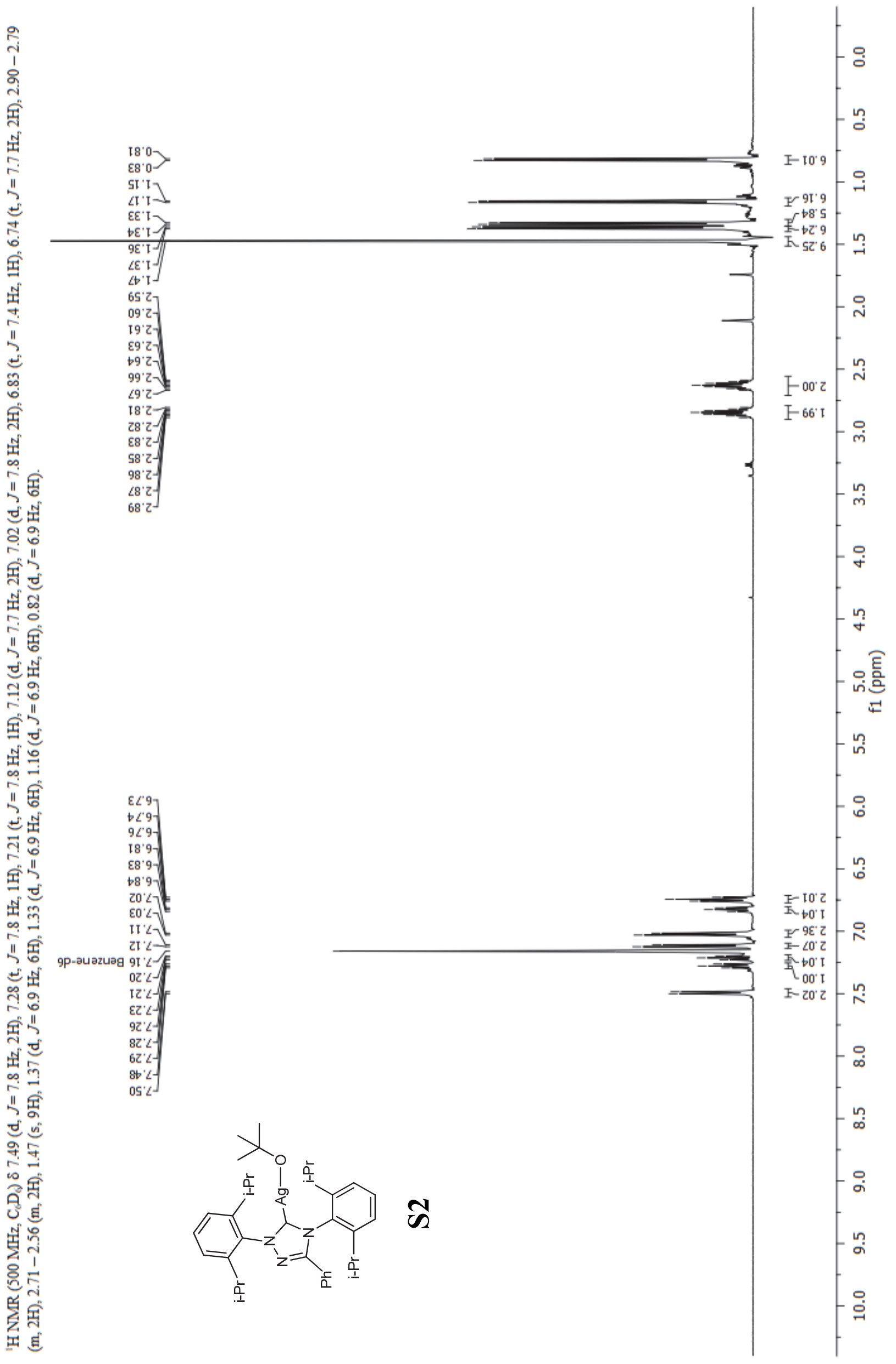



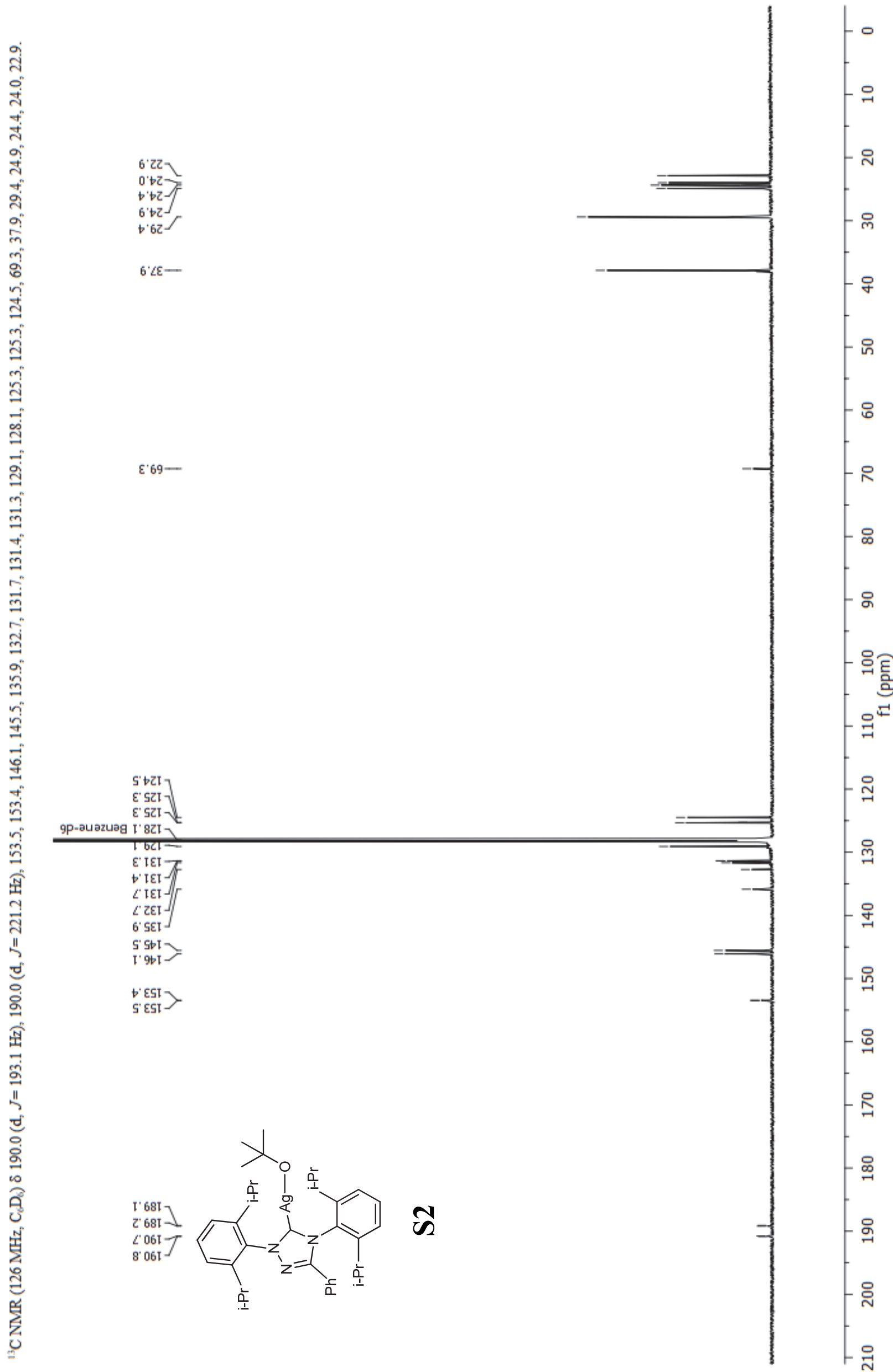


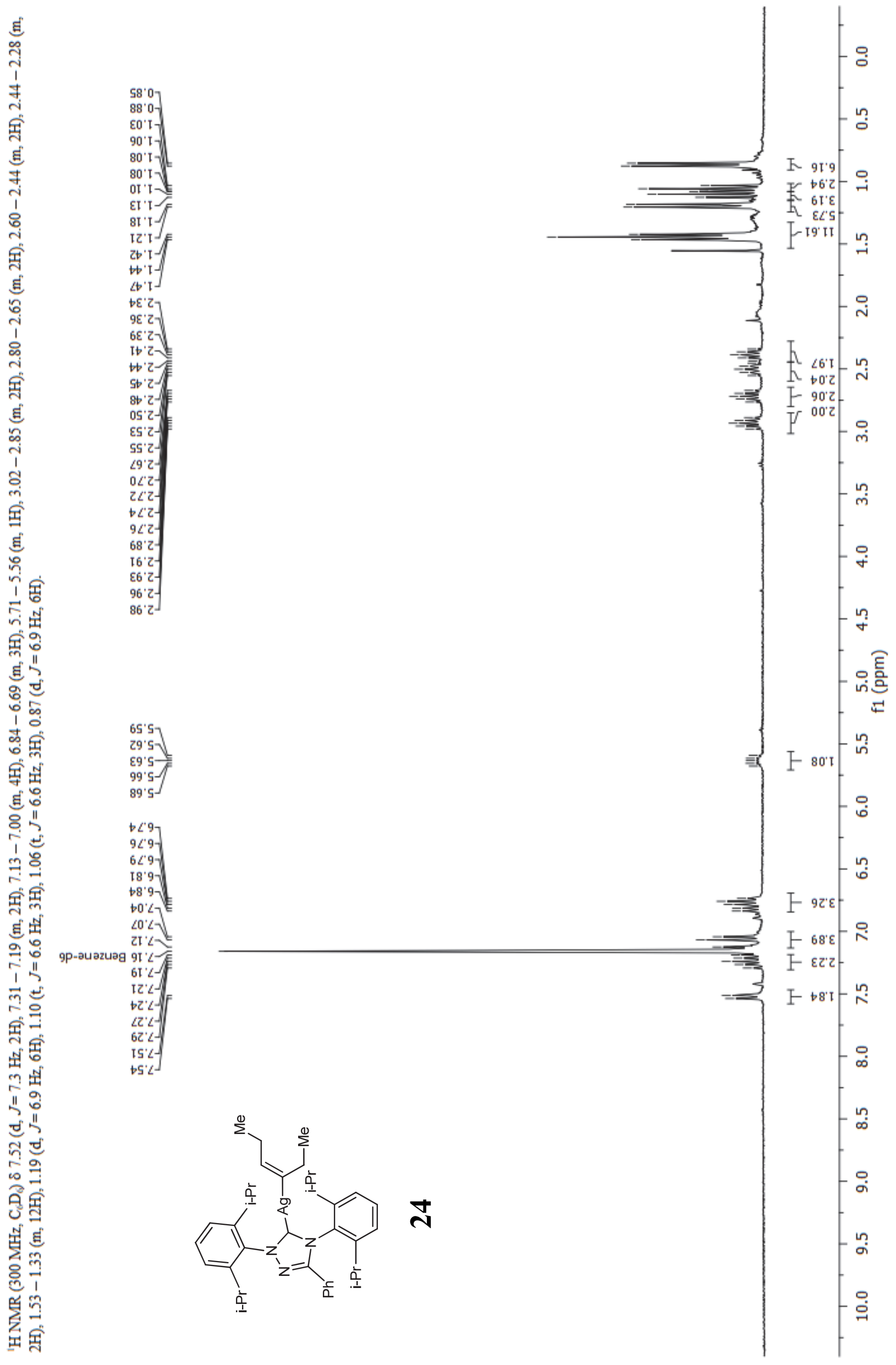




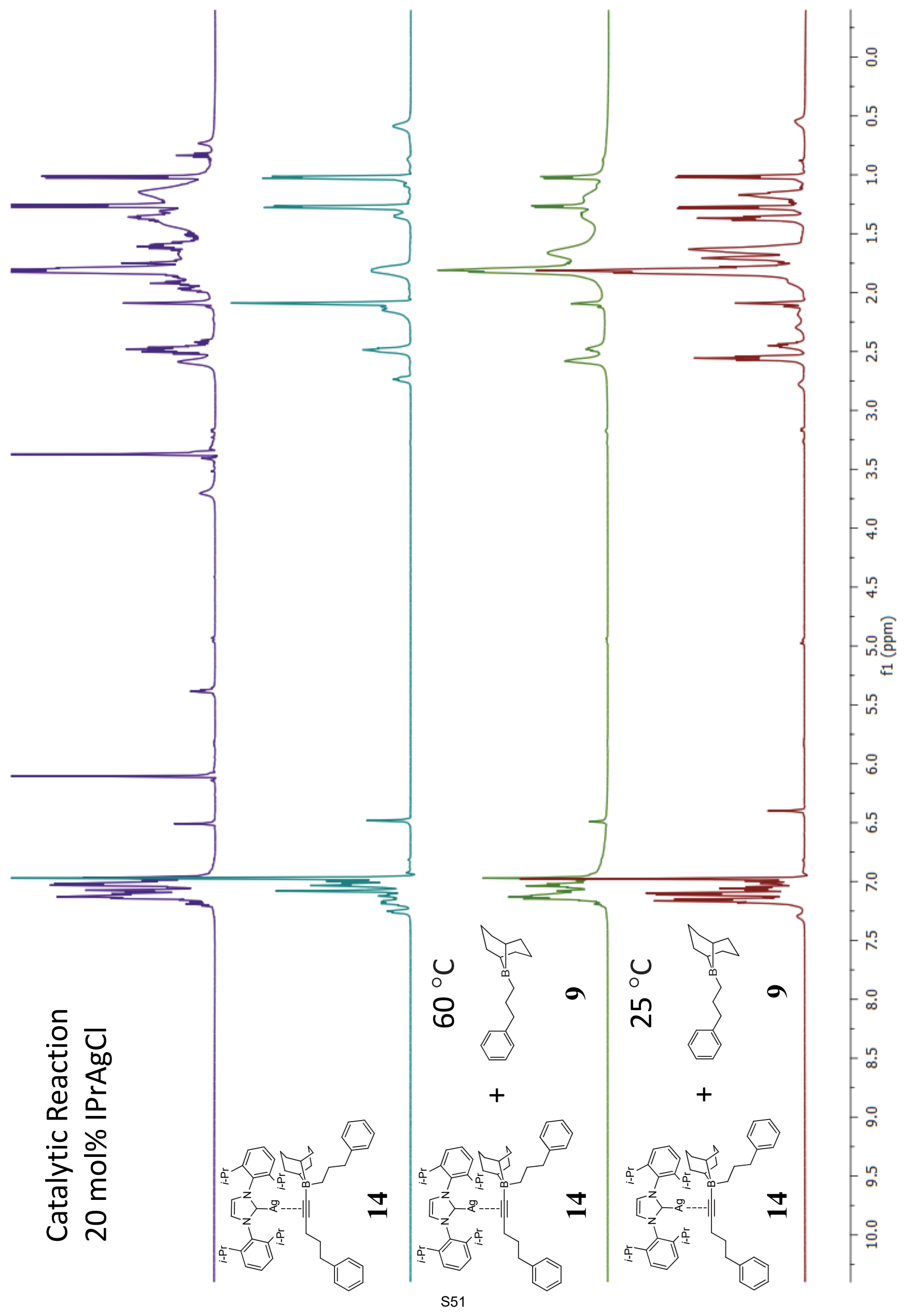




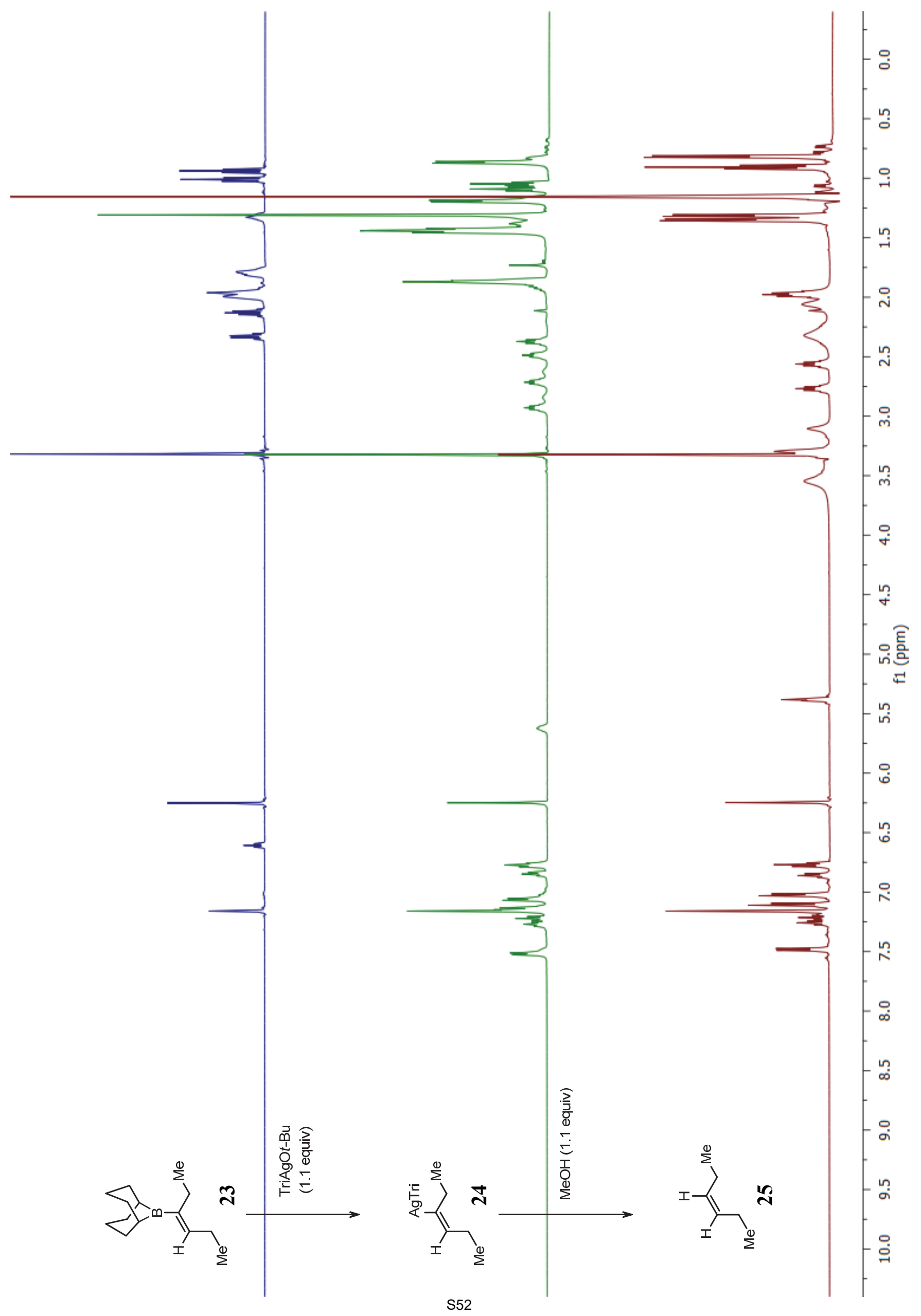

